JENNY ROSARIO NIÑO DE GUZMÁN AEDO

\title{
Atividade de álcool, aldeído e ácido perílico contra $L$. (L.) major e $L$. (L.) amazonensis
}

Dissertação apresentada ao programa de Pós-Graduação do Departamento de Parasitologia do Instituto de Ciências Biomédicas da Universidade de São Paulo para obtenção de título de Mestre em Ciências Biológicas 
JENNY ROSARIO NIÑO DE GUZMÁN AEDO

\section{Atividade de álcool, aldeído e ácido perílico contra $L$. (L.) major e $L$. (L.) amazonensis}

Dissertação apresentada ao programa de Pós-Graduação do Departamento de Parasitologia do Instituto de Ciências Biomédicas da Universidade de São Paulo para obtenção de título de Mestre em Ciências Biológicas

Área de concentração: Parasitlogia Orientadora: Prof ${ }^{a} \mathrm{Dr}^{\mathrm{a}}$. Silvia R. B. Uliana 
A meus pais pelo exemplo de luta diária frente às diversidades.A minhas irmãs Marita e July pelo otimismo frente à vida.A meu irmão Jhonatan pelos momentos simples e ocorrência sem limites.A meu sobrinho Lian pelas palavras simples de coração de criança e minha sobrinha Cristina por ser motivo alegria constante.

Obrigada a minha querida família que sempre acreditaram em mim e desde longe me deram seu amor e alento. 


\section{AGRADECIMENTOS}

À professora Silvia pela orientação, paciência, tolerância e dedicação. Sempre levarei comigo seus ensinamentos profissionais. Obrigada pela iniciação na pesquisa e seu exemplo de ética profissional.

À Fernando, meu grande amigo, obrigada pela amizade, companheirismo parceria e cumplicidades das pequenas coisas que fizeram diferença na minha passagem pelo laboratório.

Ao Danilo pelos comentários sobre meu trabalho, paciência e companheirismo dentro do laboratório.

À Jenicer por ser exemplo de organização e Camila pela sua alegria.

À Denise, Rogéria e Alessandro meus colegas de laboratório

À Marta Campaner por ser sempre ser alegre comigo e me colocar sob atenção.

Ao pessoal de Departamento de Parasitologia.

À Henry meu amigo paciente e leal, sendo uma grande ajuda para mim nestes tempos longe de minha família.

À Rogério, meu colega de apartamento pelos velhos momentos tomando chá.

À minhas grandes amigas Zorayda, Julieta e Gerby pela sua alegria, companheirismo e lealdade. Obrigada pela sua amizade e momentos de conversa que tivemos.

À Claudia por me ensinar que temos que viver a vida intensamente e ainda estou tentado aprender isso.

Ao CNPq e FAPESP que financiaram minha pesquisa 


\section{RESUMO}

NIÑO DE GUZMÁN, A.J. Atividade de álcool, aldeído e ácido perílico contra $L$. (L.) major e L. (L.) amazonensis. 2007. Dissertação (Mestrado em parasitologia\} - Instituto de Ciências Biomédicas, Universidade de São Paulo, São Paulo, 2007.

Álcool perílico $(\mathrm{POH})$, aldeído perílico $(\mathrm{PCO})$ e acido perílico $(\mathrm{PCOOH})$ são produtos encontrados em plantas, sintetizados pela via dos isoprenóides. Chamados de terpenos têm atividade antibiótica já demonstrada. Neste estudo avaliamos a atividade destas drogas para o tratamento de Leishmaniose, uma doença endêmica de 88 paises com tratamento que apresenta efeitos colaterais e casos resistência. Assim testamos estas drogas in vitro e in vivo em de $L$. (L) major e L. (L.) amazonensis. Para promastigotas da primeira espécie foi demonstrado $\mathrm{IC}_{50}$ de 0,72 $\mathrm{mM} \mathrm{POH}, 0,11 \mathrm{mM}$ PCO e 0,70 mM PCOOH e para a segunda com o $\mathrm{IC}_{50}$ de 0,90 mM POH e 0,07 mM PCO já amastigotas desta ultima teve $\mathrm{IC}_{50}$ de 0,87 mM POH e 0,12 mM PCO. Além disto foi visto que estas drogas são relativamente tóxicas em células de mamíferos. Acreditasse que estas drogas estão envolvidas na inibição da isoprenilação de proteínas, interferindo assim no processo de crescimento, diferenciação, organização e transporte celular. As P21 ras são proteínas isopreniladas, expressa em tecidos onde a alteração desta Ras produz uma célula mutante. Sendo assim nós tentamos demonstrar mediante marcação metabólica que este seria um possível mecanismo de ação destas drogas em Leishmania. Demonstramos por marcação com $\left[{ }^{35} \mathrm{~S}\right]$-metionina que as drogas nas concentrações utilizadas de $0,2 \mathrm{mM} \mathrm{POH}$ e 0,02 mM PCO não interferiam na síntese protéica. Posteriormente avaliamos mediante marcação com $\left[1(n)-{ }^{3} \mathrm{H}\right]$ - farnesil pirofosfato e $\left[1(\mathrm{n})-{ }^{3} \mathrm{H}\right]$-geranilgeranil pirofosfato precursores das P21 ras e não conseguimos observar marcação com estes intermediários. Os experimentos in vivo demonstraram que estas drogas não possuem atividade contra leishmaniose no tratamento via tópica, intra-retal ou intraperitonial.

Palavra - chave: Monoterpenos; Derivados do limoneno; Metabolitos do limoneno; Leishmania; quimioterapia. 


\section{ABSTRACT}

NIÑO DE GUZMÁN, A.J. Activity of perillyl alcohol, perillyl aldehyde and perillyl acid against $L$. (L.) major and $L$. (L.) amazonensis. 2007. Máster thesis (Parasitology) - Instituto de Ciências Biomédicas, Universidade de São Paulo, São Paulo, 2007.

Leishmanicidal properties have been ascribed to several terpenes, which are plant products formed through the pathway responsible for the synthesis of isoprenoids. Among these, limonene is a monoterpene found mainly in citric fruits. In plants and in mammalian liver, limonene is converted to perillyl alcohol $(\mathrm{POH})$, perillyl aldehyde (PCO) and perillyl acid $(\mathrm{PCOOH})$. These limonene derivatives can be purified from seeds and oils from various plants, as cherries, lavender, peppermint, and sage. Limonene and its derivatives possess antimicrobial and antineoplasic properties. In this study we evaluated the activity of $\mathrm{POH}, \mathrm{PCO}$ and $\mathrm{PCOOH}$ for the treatment of leishmaniasis, an endemic disease in 88 countries, treated with chemotherapeutic agents that are very toxic. The inhibitory concentrations for $50 \%$ of the parasites $\left(\mathrm{IC}_{50}\right)$ were determined for $L$. ( $\left.L\right)$ major and L. (L.) amazonensis promastigotes. For $L$. ( $L$ ) major, the $\mathrm{IC}_{50}$ after $24 \mathrm{~h}$ incubation for $\mathrm{POH}, \mathrm{PCO}$ and $\mathrm{PCOOH}$ were $0.72 \mathrm{mM}, 0.11 \mathrm{mM}$ and $0.70 \mathrm{mM}$, respectively. For L. (L.) amazonensis promastigotes, the $\mathrm{IC}_{50}$ for $\mathrm{POH}$ e $\mathrm{PCO}$ were $0.90 \mathrm{mM}$ and $0.07 \mathrm{mM}$ after $24 \mathrm{~h}$ and for $\mathrm{PCOOH} 2.79 \mathrm{mM}$ after $48 \mathrm{~h}$ incubation. $\mathrm{POH}$ and $\mathrm{PCO}$ activities were also demonstrated against $L$. (L.) amazonensis axenic amastigotes, with $\mathrm{IC}_{50}$ of $0.87 \mathrm{mM}$ and $0.12 \mathrm{mM}$, respectively. We have also shown that these drugs are toxic for macrophages, in concentrations in the same range as the effective ones against parasites. The in vivo toxicity evaluation, however, did not show intolerance or collateral effects in mice. There was no clinical response to the administration of $\mathrm{POH}$ or $\mathrm{PCO}$ to $L$. $(L)$ major or $L$. (L.) amazonensis infected mice. The combination of $\mathrm{POH}$ e PCO by the intraperitoneal route was able to delay the disease progression in mice infected with $L$. (L.) amazonensis.

Keywords: Leishmania; chemotherapy; monoterpene; perillyl alcohol; perillyl aldehyde; perillyl acid 


\section{LISTA DE FIGURAS}

Figura 1. Estrutura do limoneno e seus derivados

Figura 2. Efeito do álcool perílico em culturas de promastigotas de L. (L.) major e L. (L.) amazonensis.

Figura 3. Efeito do aldeído perílico em culturas de promastigotas de L. (L.) major e L. (L.) amazonensis.

Figura 4. Efeito do ácido perílico em culturas de promastigotas de L. (L.) major e L. (L.) amazonensis.

Figura 5. Efeito dos metabólitos do limoneno em culturas de amastigotas de $L$. (L.) amazonensis.

Figura 6. Toxicidade do álcool perílico, aldeído perílico e ácido perílico para células de mamíferos.

Figura 7. Toxicidade do álcool perílico e aldeído perílico para células de mamíferos.

Figura 8. Efeito do álcool e aldeído perílico no crescimento de amastigotas intracelulares

Figura 9. Efeito de álcool e aldeído perílico no crescimento de amastigotas intracelulares em macrófofagos pré-tratatados.

Figura 10. Comparação do efeito de álcool e aldeído perílico no crescimento de amastigotas intracelulares.

Figura 11. Marcação metabólica de promastigotas de $L$. (L.) amazonensis e $L$. (L.) major e amastigotas de $L$. (L.) amazonensis.

Figura 12. Análise de isoprenilação de proteínas em promastigotas

L. (L.) major .56

Figura 13. Toxicidade dos derivados do limoneno 60

Figura 14. Atividade de álcool perílico no tratamento de leishmaniose.........62

Figura 15. Atividade de álcool perílico no tratamento de leishmaniose.........63

Figura 16. Atividade de aldeído perílico no tratamento de leishmaniose......65

Figura 17. Atividade de aldeído perílico .67

Figura 18. Atividade da associação de álcool perílico e aldeído perílico por via tópica (creme). 
Figura 19. Atividade da associação de álcool perílico e aldeído perílico por via intraperitoneal.. 


\section{LISTA DE TABELAS}

Tabela 1 - IC ${ }_{50}$ de promastigotas de L. (L.) major tratados com álcool perílico, aldeído perílico e ácido perilico.

Tabela 2 - IC ${ }_{50}$ de promastigotas de $L$. (L.) amazonensis tratadas com álcool perílico, aldeído perílico e ácido perílico..

Tabela 3 - IC I0 $_{50}$ álcool perílico, aldeído perílico e ácido perílico para amastigotas de $L$. (L.) amazonensis.

Tabela 4 - $\mathrm{CC}_{50}$ de macrófagos e fibroblastos tratados com álcool perílico, aldeído perílico e ácido perílico.

Tabela 5 - Atividade de álcool perílico e aldeído perílico em amastigotas intracelulares.

Tabela 6 - Atividade de álcool perílico e aldeído perílico em amastigotas intracelulares.

Tabela 7 - Atividade do pré-tratamento de álcool perílico e aldeído perílico em amastigotas intracelulares 


\section{SUMÁRIO}

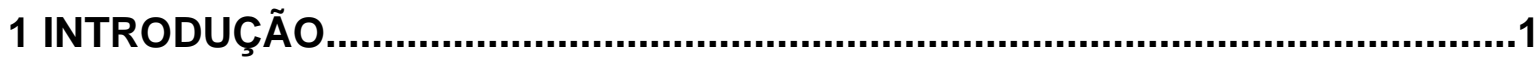

1.1 Aspectos gerais....................................................................................

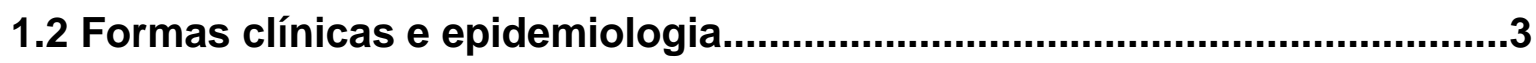

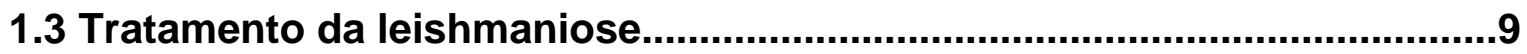

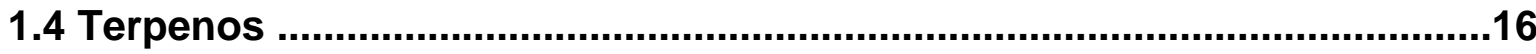

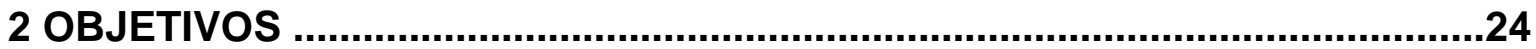

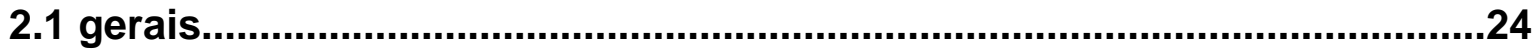

2.2 Específicos..........................................................................................24

3 MATERIAIS E MÉTODOS..........................................................................25

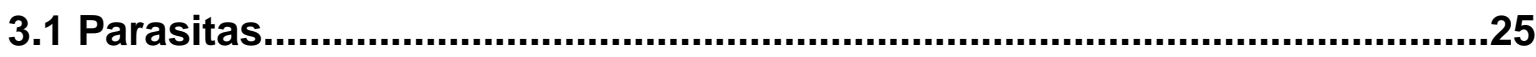

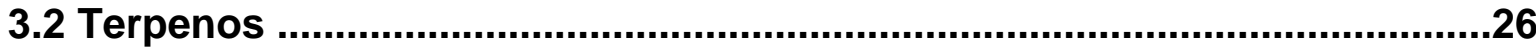

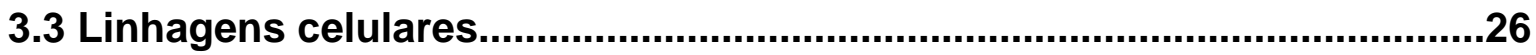

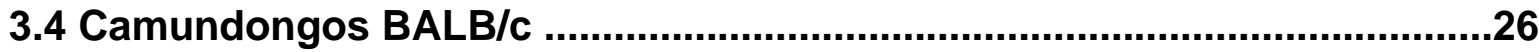

3.5 Obtenção de macrófagos residentes de peritônio .....................................26

3.6 Inibição de crescimento de promastigotas e amastigotas de

Leishmania sp. na presença de álcool, aldeído e acido perílico....................27

3.7 Teste do MTT .......................................................................................27

3.8 Teste de citotoxicidade das linhagens celulares

na presença de álcool, aldeído e ácido perílico.............................................28

3.9 Inibição de crescimento de amastigotas intracelulares............................28

3.10 Quantificação de óxido nítrico (NO) por reação de Griess......................29

3.11 Preparações de toxicidade de álcool e aldeído perílico para uso in vivo

3.12 Teste de atividade de álcool e aldeído

perílico em camundongos infectados com Leishmania.................................31

3.13 Marcação metabólica com metionina.........................................................31

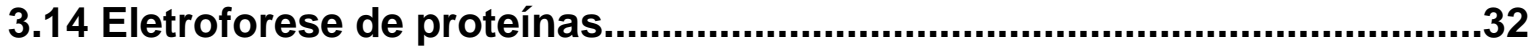

3.15 Análise de isoprenilação de proteínas................................................ 32

3.16 Análise estatística........................................................................................33 
4 RESULTADOS.

4.1 Determinação da atividade dos derivados do limoneno in vitro.

4.1.1 Atividade dos derivados do limoneno e cálculo da concentração inibitória 50\% (IC50) para promastigotas de L. (L.) major e L. (L.)

amazonensis. .34

4.1.2 Determinação da atividade dos derivados do limoneno e cálculo de IC50 em amastigotas.

4.1.3 Citotoxicidade dos derivados do limoneno e cálculo da concentração citotóxica em células.

4.1.4 Atividade de álcool perílico e aldeído perílico em amastigotas intracelulares.

4.1.5 Produção de óxido nítrico (NO) em macrófago tratados e pré-tratados com álcool perílico e álcool e aldeído perílico. 53

4.1.6 Análise da isoprenilacão de proteínas em parasitas tratados com álcool perílico e aldeído .54

4.2 Determinação da atividade dos derivados do limoneno em experimentos in vivo

4.2.1 Toxicidade do álcool perílico e aldeído perílico em camundongos

BALB/C .58

4.2.2 Álcool perílico no tratamento de leishmaniose experimental. .59

4.2.3 Aldeído perílico no tratamento de leishmaniose experimental. .63

4.2.4 Determinação da atividade da associação de álcool perílico e aldeído perílico no tratamento. .66

5 DISCUSSÃO .69

REFERÊNCIAS BIBLIOGRÁFICAS. 81 


\section{INTRODUÇÃO}

\subsection{Aspectos gerais}

Leishmaniose é uma doença causada por parasitas flagelados que pertencem à ordem Kinetoplastida, família Trypanosomatidae e gênero Leishmania. Os protozoários desta ordem caracterizam-se pela presença de uma estrutura interna à mitocôndria, chamada cinetoplasto, formada por uma rede de moléculas de DNA concatenadas (LAINSON; SHAW, 1987).

Existem evidências de que a doença estivesse presente nas Américas, entre as civilizações pré-inca, antes da chegada dos conquistadores neste continente. Em 1903 Leishman e Donovan descreveram o primeiro caso de leishmaniose na África e, na atualidade, a organização Mundial da Saúde considera a leishmaniose como um dos maiores problemas de saúde pública no mundo. Essa doença afeta 12 milhões de pessoas em 88 países tropicais e subtropicais, sendo que 72 desses são considerados em vias de desenvolvimento. Cerca de 350 milhões de pessoas vivem em áreas de risco de aquisição da infecção sendo 1,5 a 2 milhões de casos novos registrados anualmente (ORGANIZAÇÃO MUNDIAL DA SAÚDE, Leishmaniasis. Disponível em: http://www.who.int/leishmaniasis/burden/magnitude/burdenmagnitude/em lindex.html > Acesso em:11maio. 2007).

Os membros da família Trypanosomatidae apresentam divisão binária simples, podem ter ciclo de vida monoxênico, parasitando somente invertebrados, ou então apresentar um ciclo de vida heteroxênico tendo como hospedeiros tanto invertebrados quanto vertebrados (REY, 2001). A família Trypanosomatidae compreende gêneros tais como Leishmania, Trypanosoma, Leptomonas, 
Herpetomonas, Crithidia, Blastocrithidia, Endotrypanum e Phytomonas que são parasitos de invertebrados, vertebrados e plantas (CAMARGO et al.,1997).

Parasitas do gênero Leishmania são classificados em dois subgêneros: Viannia e Leishmania. Os parasitas do subgênero Viannia desenvolvem-se primeiramente no intestino posterior dos vetores e depois migram para o intestino médio e anterior (secção Peripilária). Os parasitas do subgênero Leishmania desenvolvem-se apenas no intestino anterior e médio (secção Suprapilária) (LAINSON; SHAW, 1987). O gênero Leishmania abrange cerca de 30 espécies catalogadas das quais 20 estão implicadas em doença em humanos (ASHFORD, 2000).

O ciclo biológico de Leishmania é heteroxeno, envolvendo um hospedeiro invertebrado e um vertebrado. Os hospedeiros invertebrados são flebotomíneos hematófagos do gênero Lutzomya, no Novo Mundo, ou Phebotomus, no Velho Mundo (ROBERTS; JANOVY, 2000).Esses pequenos dípteros têm preferência por lugares úmidos e quentes. Estima-se que existam cerca de 400 espécies de flebotomíneos nas Américas sendo que 50 dessas parecem estar envolvidas na transmissão de Leishmania (KILLICK-KENDRICK, 1999). Além de um vetor invertebrado, o parasita precisa de um hospedeiro vertebrado que serve como reservatório. Dentre esses temos uma ampla variedade de roedores, canídeos, marsupiais e humanos. Geralmente, o homem participa do ciclo de transmissão como um hospedeiro acidental, quando entra nos ambientes de alta transmissão onde a doença se mantém graças aos reservatórios naturais (MOLYNEUX; KILLICK-KENDRICK, 1987).

Leishmania apresenta duas formas no seu ciclo de vida: a forma extracelular promastigota, que é fusiforme, apresenta núcleo central e possui flagelo, organela 
relacionada à locomoção do parasita no tubo digestivo do inseto e a forma amastigota que é ovalada, não apresenta flagelo e é encontrada no interior dos fagolisossomos dos macrófagos (ROBERTS; JANOVY, 2000; GANTT et al., 2001).

O ciclo começa quando o inseto ingere sangue de um hospedeiro vertebrado infectado, contendo macrófagos que possuem amastigotas no seu interior. Depois da lise do macrófago infectado, os amastigotas transformam-se em promastigotas, que aderem às microvilosidades do intestino médio. Nesta fase, os parasitas se denominam procíclicos e se caracterizam por multiplicar-se rapidamente por divisão binária, transformando-se após alguns dias em promastigotas metacíclicos que são muito móveis e não têm a capacidade de se dividir. Os promastigotas metacíclicos, infectantes, migram para a probóscide do inseto e são injetados com a saliva durante o próximo repasto sanguíneo (BATES, 1994; SACKS; KAMHAWI, 2001).

Os promastigotas inoculados sobrevivem aos mecanismos de defesa inatos do hospedeiro e então infectam os macrófagos. Dentro dos macrófagos forma-se o fagossomo, local onde o promastigota metacíclico sobrevive e estabelece condições favoráveis para a sua diferenciação em amastigotas, que se dividem, lisam o macrófago e infectam novas células, repetindo o ciclo (BATES, 1994; GANTT et al., 2001; SACKS; KAMHAWI, 2001).

\subsection{Formas clínicas e epidemiologia}

A doença apresenta diferentes manifestações clinicas: as formas cutâneas, que se caracterizam por lesões ulcerosas únicas ou múltiplas na pele, geralmente no rosto, braços e pernas; a forma cutânea difusa, com lesões nodulares persistentes no corpo inteiro; a forma mucocutânea, que afeta de maneira 
preponderante as mucosas da face como fossas nasais e pálato e o tabique auricular; e a forma visceral, que se caracteriza pelo aumento do volume do fígado e baço, anemia, perda de peso e febre, e que, se não for tratada a tempo, pode ser fatal (HEPBURN, 2000).

Segundo a Organização Mundial da Saúde, de 1 a 1,5 milhão dos casos anuais correspondem à forma cutânea, ocorrendo principalmente em países em vias de desenvolvimento na Ásia, África e América Latina. Cerca de $90 \%$ dos casos estão concentrados entre Afeganistão, Algéria, Irã, Iraque, Arábia Saudita e Síria na África, e no Brasil e Peru nas Américas (ASHFORD, 2000). A incidência de leishmaniose visceral chega aproximadamente a 0,5 milhão de casos ocorrendo a maioria destes na Índia, Sudão, Bangladesh e Nepal, na África e Ásia, e no Brasil nas Américas, onde está distribuída desde os Estados Unidos até o norte da Argentina (ORGANIZAÇÃO MUNDIAL DA SAÚDE, Leishmaniasis. Disponível em: http://www.who.int/dr/dw/leish2004.htm > acesso em: 24 Abril, 2007).

No Brasil tem-se observado, na última década, a expansão das áreas consideradas endêmicas assim como a eclosão de surtos epidêmicos em regiões antes consideradas livres da doença. Entre os fatores que contribuem para este crescimento temos indivíduos que visitam áreas endêmicas ou indivíduos portadores que migram a outras regiões (SCHWARTZ et al., 2006), além de surtos epidêmicos associados à aceleração do desmatamento para as expansões agrícolas e urbanas, entre outras atividades (DESJEUX, 2001).

Leishmaniose no Brasil é considerada como a sexta doença infecciosa com maior incidência confirmada, de acordo com o Ministério da Saúde. O número de casos anuais de leishmaniose tegumentar passou de 4560 a 28712 no período de 1980 a 2004. Aumento ainda mais expressivo foi registrado em relação à 
leishmaniose visceral, com 164 casos em 1980 e 3366 casos em 2004. A expansão na distribuição geográfica dos casos de leishmaniose tegumentar no Brasil também é bastante evidente: em 1994, havia registros de casos autóctones em 1861 municípios, distribuídos entre 20 estados da federação. Em 2002, observou-se expansão da doença para 2302 municípios, distribuídos por todos os estados. As regiões Nordeste e Norte são as de maior incidência, seguidas pela região Centro-Oeste.

A distribuição dos casos de leishmaniose visceral no Brasil também tem sofrido alterações. Sua ocorrência, antes limitada a áreas rurais nos estados do Nordeste, está atualmente distribuída entre regiões urbanas e rurais em 19 estados da federação. A região de maior incidência ainda é a região Nordeste, seguida pelas região Sudeste, Norte e, finalmente, Centro-Oeste. A mortalidade tem se mantido em torno de $10 \%$ dos casos notificados (MINISTÉRIO DA SAÚDE, Tópicos de saúde. Disponível: http://portal.saude.gov.br/portal/saude/> acesso em 24 julho, 2007).

A forma clínica cutânea de leishmaniose também é conhecida como ferida brava ou úlcera de Bauru. Esta é a forma mais comum de leishmaniose e caracteriza-se pela presença de lesões cutâneas de vários tipos, geralmente manifestando-se como úlcera crônica que pode disseminar progressivamente afetando linfonodos e causando metástases (ASHFORD, 2000; HEPBURN, 2000).

Depois de um período de incubação, que varia entre duas semanas a dois meses, aparece a lesão inicial que é geralmente única, crescendo lentamente e ulcerando depois de alguns meses. As lesões podem chegar a medir vários centímetros com características típicas como contornos regulares, inodoras, pouco exsudativas e com fundo granuloso. Também se observam outros tipos de lesões como úlcero-costrosas, ectimatóides, úlcero vegetantes, verrucosas e outras. As 
lesões da pele podem curar espontaneamente deixando cicatrizes visíveis após curso crônico de meses a anos (REY, 2001).

$\mathrm{Na}$ forma cutânea difusa, as lesões são papulosas ou nodulares deformantes, não se observando ulceração das lesões. Estas se distribuem amplamente na superfície corporal, onde são encontrados abundantes macrófagos repletos de amastigotas (WALTON, 1987). Esta forma de leishmaniose se apresenta raramente, não cura espontaneamente, é de difícil tratamento e apresenta recaída após a terapia (SOUZA et al., 2006).

A leishmaniose mucocutânea caracteriza-se por lesões tardias, que surgem geralmente meses ou anos após a cura de uma lesão cutânea (WALTON, 1987), preferencialmente no tabique auricular ou nasal que se estende progressivamente aos tecidos moles com inflamação e ulceração. Posteriormente, a lesão se aprofunda para destruir o tecido em vários anos. Nestas lesões se encontram poucos parasitas (MARKELL et al., 2003).

Nas Américas, a leishmaniose cutânea é freqüentemente causada pelas espécies L. (V.) braziliensis, L. (L.) amazonensis, L. (L.) mexicana, L. (V.) peruviana, L. (V.) panamensis e L. (V.) guyanensis; no Velho Mundo as espécies L. (L.) major, L. (L.) tropica e L. (L.) aethiopica são as responsáveis por esta forma clínica (GRIMALDI; TESH, 1993; WILLIAMS, 1995). A espécie mais destrutiva causadora de leishmaniose mucocutânea é L. (V.) braziliensis (ABRAMSON et al., 1995).

A leishmaniose visceral, chamada também Kalazar, febre negra ou esplenomegalia tropical, é uma doença crônica e endêmica em várias regiões do mundo, afetando especialmente crianças e pessoas imunodeprimidas, caracterizando-se por febre irregular e esplenomegalia (SILVA et al., 2001). 
O período de incubação varia de dois a oito meses. O início da doença é insidioso, com perda de apetite, palidez, aparecimento de febre alta, que é o sintoma mais notável pela sua constância, aumento de volume do baço, anemia e hemorragias da gengiva e digestiva (FURTADO, 1994). A alteração do apetite leva a desnutrição grave e a evolução da doença pode ser rápida, levando à morte em algumas semanas. Além disso, a susceptibilidade a diversas infecções bacterianas pode agravar o quadro clínico (SAMUELSON, 2000).

Os pacientes podem apresentar uma forma crônica assintomática da doença, com curso lento que pode durar anos, ou a forma aguda que é rápida e fatal. Na Ásia, África e Europa a leishmaniose visceral pode ser causada por L. (L.) donovani ou L. (L.) infantum, enquanto que nas Américas L. (L.) chagasi é responsável por esta forma de leishmaniose (BAILY; NANDY, 1994).

L. (L.) amazonensis e L. (L.) major foram utilizadas neste estudo. A primeira encontrase nas florestas da Amazônia, seus hospedeiros naturais são os marsupiais e roedores silvestres como Proechimys, Oryzomys, Marmosa entre outros. Seus vetores são Lutzomyia flaviscutellata, Lu. reducta e Lu. olhmeca que têm hábitos de vôo baixo e são pouco antropofílicos (LEWIS; WARD, 1987). A forma clínica predominante na infecção por esta espécie é a forma cutânea. Por outro lado, em um pequeno número de pacientes, esta espécie está relacionada ao aparecimento da forma cutânea difusa. Já $L$. (L.) major é de distribuição rural na Ásia, seus hospedeiros naturais são roedores do gênero Rhombomys, Merianes e outros (SHAW, 1987), vivem nas áreas endêmicas aos vetores, que são Phebotomus papatasi, Ph. caucasicus e Ph. andrejevi que têm hábitos bastantes zoofílicos (ADLER; THEODOR, 1957). 
A resposta imune adquirida do hospedeiro contra Leishmania é mediada pela resposta de tipo celular, já que o parasita escapa da resposta humoral, por residir dentro do macrófago (CUNNINGHAM, 2002). Pelo menos nas infecções por L. (L.) major, a susceptibilidade ou a resistência ao parasita parecem estar relacionadas ao perfil de resposta celular desencadeada pela infecção (SCOTT, 1991), sendo que o predomínio de resposta de tipo Th1 estaria relacionado à resistência enquanto que respostas com perfil Th2 estariam presentes nos hospedeiros susceptíveis (MOSMANN, 2000).

Os mecanismos para a diferenciação de linfócitos T CD4+ em tipos Th1 ou Th2 após a infecção por Leishmania ainda não estão totalmente esclarecidos, mas vários fatores têm sido implicados, sendo a desnutrição um deles (PEARSON; SOUSA, 1996) além do genótipo do parasita, tamanho do inóculo, zona de inoculação, número de picadas recebidas, a virulência, saliva do flebótomo e fatores genéticos ligados ao hospedeiro que podem incidir no desenvolvimento da resposta celular (MAUEL et al., 1981). Outros fatores são os tipos de células apresentadoras do antígeno (ROSSI-BERGMANN et al., 1993), os níveis de citocinas endógenas (VIEIRA et al., 1994) a natureza do antígeno reconhecido (SCOTT et al., 1988) entre outras.

Os linfócitos $\mathrm{Th}_{1}$ secretam citocinas como interleucina 2 (IL - 2), interferon gama (INF $\gamma$ ) e fator de necrose alfa (TNF $\alpha$ ), as quais ativam macrófagos imaturos e infectados (THEODOS et al., 1991), estimulando a produção da enzima óxido nítrico sintase induzida (iNOS), que resulta na produção de oxido nítrico (NO), molécula envolvida na resposta imune contra Leishmania (KANE; MOSSER, 2000).

O parasita sobrevive dentro do macrófago mediante a habilidade de inibir a expressão ou atividade de iNOS através da inibição da produção de citocinas 
envolvidas na regulação de iNOS (BALESTIERI et al., 2002), inibição da síntese de NO por glicosilinositol fosfolipídeos (GIPL) da superfície de amastigotas (PROUDFOOT et al., 1995) ou estímulo à produção do fator de transformação do crescimento TGF- $\beta$, que inibe a síntese de NO (BARRAL-NETTO et al., 1992).

Os camundongos utilizados neste trabalho são da linhagem BALB/c que são geneticamente susceptíveis, desenvolvendo lesões cutâneas no sitío da inoculação. A infecção destes camundongos por L. (L.) amazonensis e L. (L.) major resulta em doença progressiva e severa, com edema e formação de tumor no local da inoculação, seguido por necrose e perda tecidual. A doença induzida pela inoculação de L. (L.) amazonensis se apresenta com curso progressivo rapidamente agressivo que, após alguns meses, evolui a metástases à distância, enquanto que a infecção por L. (L.) major induz doença progressiva de curso lento afetando o local da infecção.

\subsection{Tratamento da leishmaniose}

O antimônio foi introduzido na terapêutica médica no século XV, empregado para diversas afecções. Sua toxicidade, e ineficácia em muitos pacientes, fizeram com que seu uso fosse proibido. Em 1630, o sal de antimônio trivalente, denominado emético, foi introduzido em medicina. Sua utilização foi novamente abandonada durante os séculos XVIII e XIX até que, em 1907, foi relatada a atividade do tártaro emético contra tripanossomas africanos. Em 1912 foram publicados os resultados obtidos por Vianna no tratamento da úlcera de Bauru e, cerca de 3 anos depois, o tártaro emético estava já sendo empregado em larga escala no tratamento de leishmaniose visceral na Índia, sendo responsável pela 
redução da mortalidade dessa doença, de cerca de 90 para $5 \%$ dos pacientes (BRYCESON, 2000).

Os antimoniais trivalentes, extremamente tóxicos, foram, a partir de 1920, substituídos pelos antimoniais pentavalentes e, a partir dos anos 40, o estibogluconato de sódio e o antimoniato de meglumine passaram a representar os medicamentos de primeira escolha para o tratamento de leishmaniose (CROFT; YARDLEY, 2002).

O mecanismo de ação dos antimoniais ainda não está bem esclarecido. Dentre os vários alvos potenciais descritos como responsáveis pela atividade antiLeishmania desses compostos estão a glicólise (BERMAN et al., 1987), DNA topoisomerase I (LUCUMI et al., 1998), oxidação de ácidos (BERMAN et al., 1989) e tripanotiona reductase (CUNNINGHAM et al., 1994). Esta última é uma enzima análoga à glutationa redutase em mamíferos, que participa na proteção celular contra o estresse oxidativo, comprometendo o potencial redox da célula e induzindo a acumulação de disulfitos (CUNNINGHAM; FAIRLAMB, 1995). Há ainda evidências de que antimoniais poderiam agir desencadeando apoptose (SERENO et al., 2001).

Os antimoniais pentavalentes $\left(\mathrm{Sb}^{\vee}\right)$ são administrados por via parenteral. No interior do macrófago, são convertidos em antimoniais trivalentes (Sb $\left.{ }^{\text {III }}\right)$, compostos mais tóxicos contra os dois estágios de Leishmania (FREZARD et al., 2001) e também para o homem.

Estas drogas induzem uma variedade de efeitos adversos, alguns deles bastantes graves como: artralgias, mialgias, anorexia, náuseas, vômitos, plenitude gástrica, dor abdominal, febre, fraqueza, cefaléia, tontura, palpitações, insônia, nervosismo, insuficiência renal, arritmias, anemia e tosse (RAVDIN, 1990; KHAW; 
PANOSIAN, 1995). Outros efeitos também podem ocorrer como supressão da medula óssea, hepatotoxicidade e pancreatite química (HEPBURN, 2000). A eficácia destas drogas é variável devido à dosagem baixa e descontínua sendo as causas de maior importância no número de recaídas e resistência de Leishmania (SUNDAR et al., 2001).

Anfotericina B é a droga de segunda escolha, sendo altamente efetiva no tratamento das leishmanioses resistentes aos antimoniais (OLLIARO; BRYCESON, 1993). O metabolismo dos esteróis em Leishmania é particular sendo ergosterol o mais importante esterol de membrana neste parasita o que o diferencia da célula hospedeira, onde o colesterol é o componente esterol predominante na membrana plasmática (BEACH et al., 1998). O macrolídeo anfotericina B tem alta afinidade por episterol, que é um precursor do ergosterol (SINGH et al., 2006) o que leva a uma alteração na composição da membrana, produzindo poros e alterando a permeabilidade, o que conduz a escape de íons e, portanto, morte do parasito (LYMAN; WALSH, 1992; BALANA-FOUCE et al., 1998).

A anfotericina B é administrada por via endovenosa sendo seu uso limitado devido à sua toxicidade, apresentando efeitos como anafilaxia, trombocitopenia, anorexia, anemia, dor muscular, febre, tremor, calafrio, disfunção renal (KHAW; PANOSIAN, 1995). Novas formulações de anfotericina associada a lipídeos conferem propriedades peculiares resultando na preferencial sensibilidade de macrófagos infetados por Leishmania além de apresentarem grande redução da toxicidade (DAVIDSON et al., 1994; HAY, 1994; SEAMAN et al., 1995).

Entre essas formulações temos anfotericina B lipossomal (Ambisome), anfotericina B em complexos lipídicos (Abelcet) e anfotericina B colesterol dispersão (Anfotec), que estão sendo aplicadas com êxito para leishmaniose 
visceral. Existem diferenças regionais na resposta a essas formulações que podem ser devidas à espécie de Leishmania, carga parasitária ou idade do paciente. Na Índia onde o kalazar ocorre em crianças e adultos, a melhor resposta é obtida com Ambisome e Abelcet. No Brasil, onde a maioria dos casos se dá em crianças, Anfotec parece ser mais efetivo enquanto no Mediterrâneo, onde crianças jovens são atingidas, altas doses de Ambisome são necessárias (MURRAY et al., 2005). Entretanto, os altos custos são o principal fator limitante em países onde a doença é endêmica (BERMAN, 1998).

A pentamidina é uma diamina aromática que pode ser usada em leishmaniose resistente aos antimoniais (SANDS et al., 1985; HERWALDT, 1999). Tem sido aplicada no Brasil principalmente para o tratamento de infecções por $L$. (V.) guyanensis, que geralmente respondem mal ao tratamento com antimoniais. Seu mecanismo de ação não está bem definido, mas parece ocorrer inibição da síntese das poliaminas arginina, putrescina e espermidina (BRAY et al., 2003). Essa droga também pode atuar como intercalante de DNA do cinetoplasto e da mitocôndria (HENTZE; KOBAYASHI, 1977), interferindo na replicação, transcrição ou ambas (SANDS et al., 1985; KANDPAL et al., 1995; BASSELIN et al., 1998). Estudos recentes têm demonstrado que a mitocôndria é um importante alvo desta droga (BASSELIN et al., 2002), afetando também o potencial de membrana (VERCESI; DOCAMPO, 1992; CROFT et al., 2006).

Esta diamina deve ser administrada por via endovenosa e com freqüência produz efeitos adversos como taquicardia, hipotensão, dor de cabeça, vômitos, náuseas, erupção cutânea, disfunção renal e outros como hipoglicemia ou hiperglicemia (CONTE, 1991). Menos freqüentemente, induz arritmias, alucinações, leucopenia, febre e hipocalcemia (VOHRINGER; ARASTEH, 1993). 
A paromomicina é um antibiótico da família dos aminoglicosídeos que, além da aplicação parenteral, está sendo avaliada por via tópica em leishmaniose cutânea (EL-ON et al., 1992). Seu mecanismo de ação é desconhecido, mas sabese que altera a síntese de proteína e sugeriu-se que interfere na cascata mitocondrial com a perda do potencial de membrana e respiração, através da inibição no abastecimento de substratos para o metabolismo da mitocôndria (MAAROUF et al., 1997a). Existem também evidências de que esse antibiótico altere a captação de precursores de macromoléculas dificultando o crescimento do parasita e de que altere a composição de lipídeos na membrana, provocando diminuição da fluidez (MAAROUF et al., 1997b).

Miltefosine é um derivado alquil-lisofosfolipídico, com atividade antiproliferativa, que foi inicialmente testado por suas propriedades anti-tumorais. Recentemente, começou a ser utilizado para o tratamento de leishmaniose visceral, constituindo-se na primeira droga bem sucedida por via oral (CROFT et al., 2006). Esta droga está sendo avaliada em diferentes partes do mundo. Os testes realizados na Índia indicaram boa atividade para leishmaniose visceral, com eficácia de 95\% (BHATTACHARYA et al., 2007). Já nas Américas, testada para o tratamento de leishmaniose cutânea apresentou diferentes resultados clínicos: na Colômbia sua utilização levou à cura em $91 \%$ dos pacientes enquanto que na Guatemala a eficácia foi de 53\% (SOTO; BERMAN, 2006). A atividade in vitro de miltefosine contra diversas espécies de Leishmania mostrou ser bastante variável, sendo que os isolados de L. (L.) donovani apresentaram concentrações inibitórias para $50 \%$ dos parasitas $\left(\mathrm{IC}_{50}\right)$ de cerca de 0.04 a $8.7 \mu \mathrm{g} / \mathrm{mL}$ enquanto as $\mathrm{IC}_{50}$ para vários isolados de L. (V.) braziliensis e L. (L.) mexicana foram maiores que 30 $\mu \mathrm{g} / \mathrm{mL}$ (YARDLEY et al., 2005). A atividade do miltefosine contra Leishmania está 
relacionada à alteração da composição da membrana, com redução do conteúdo de fosfatidilcolina e ergosterol (RAKOTOMANGA et al., 2007).

As reações adversas mais freqüentes relacionadas ao uso de miltefosine são distúrbios gastrointestinais transitórios como vômitos e diarréia. A maior limitação ao seu uso até o momento está relacionada aos efeitos teratogênicos (CROFT; COOMBS, 2003; BHATTACHARYA et al., 2004).

Um terceiro grupo de drogas em estudo na atualidade é representado por bifosfonatos, como residronato e pamidronato. Estes compostos parecem interferir na síntese de farnesil pirofosfato e geranil pirofosfato, que são metabólitos chave para a isoprenilação de proteínas (MARTIN et al., 2001). São compostos com atividade leishmanicida, mas também apresentam alta toxicidade (RODRIGUES et al., 2002).

Atividade antileishmania foi também demonstrada para compostos azólicos, tais como cetoconazol e itraconazol (BERMAN et al., 1986; URBINA, 1997), mas testes clínicos revelaram ineficácia no tratamento de leishmaniose humana (NAVIN et al., 1992; MURRAY et al., 2005; CROFT et al., 2006). Mais recentemente, um outro fármaco desse grupo, o fluconazol, está sendo testado para a forma cutânea com resultados favoráveis, devido à sua alta concentração na pele. O mecanismo de ação desses compostos está baseado na inibição da síntese do lanosterol (NAVIN et al., 1992; OLLIARO; BRYCESON, 1993). Seus efeitos colaterais são geralmente hepatotoxicidade, prejuízo na produção de testosterona e disfunção renal (VIDAL-PUIG et al., 1994).

O alopurinol é utilizado como substrato por várias enzimas na via das purinas em tripanosomatídeos, podendo ser seletivamente incorporado em vários nucleotídeos intermediários no parasita e, portanto, levando a inibição da síntese 
de novas purinas (MARR,1991). Usado no tratamento de leishmaniose canina, tem pouca eficácia em humanos, devido ao rápido metabolismo e excreção do fármaco, mas poderia ter aplicação em combinação com outras drogas (NELSON et al., 1979).

Durante mais de 70 anos, apesar de sua alta toxicidade, os antimoniais pentavalentes têm sido utilizados como drogas de primeira escolha para tratar leishmaniose cutânea e visceral. A anfotericina B liposomal, pentamidina, paromomicina e miltefosine são drogas de interesse por representar novas alternativas de tratamento contra a esta doença, no entanto problemas como efeitos colaterais, preço do produto, produção da formulação seguem sendo os grandes problemas.

Além da toxicidade que possuem os medicamentos anti-Leishmania, outro grave problema que dificulta o tratamento da doença recai no desenvolvimento de resistência do parasito (NARE et al., 1997; MCCKEROW, 1990; THAKUR et al., 2001). Temos assim que o uso de antimoniais como a primeira linha de tratamento em muitas partes do mundo está ameaçado dado o desenvolvimento de resistência nestes últimos 15 anos. Recentes estudos realizados demonstram que na Índia quase $80 \%$ dos parasitos isolados são resistentes aos antimoniais (SUNDAR et al., 2001). Um dos mecanismos de resistência induzida aos antimoniais já identificado é a amplificação do gene que codifica um transportador do tipo $A B C$, responsável pela extrusão da droga (HAIMEUR; OUELLETTE, 1998). Outros mecanismos, entretanto, parecem estar associados à resistência natural (SINGH et al., 2003).

No caso das drogas de segunda escolha, como a anfotericina e pentamidina, não parece que a resistência seja uma limitante para seu uso clinico (PEREZ VICTORIA et al., 2002). Até o momento não existem registros de 
resistência aos compostos ainda em fase de avaliação para tratamento de leishmaniose como paromomicina, azóis e bifosfonatos, possivelmente devido a seu uso limitado até o momento. Entretanto, sabe-se que a obtenção de cepas resistentes in vitro ao miltefosine é bastante fácil, pelo que as expectativas de seu uso em larga escala se tornam um tanto limitadas.

A busca por compostos ativos que possam dar origem a novas drogas antiLeishmania tem sido bastante ativa nos últimos anos. Desde buscas em larga escala, a partir de bibliotecas de compostos sintéticos, a testes individuais de compostos naturais de várias naturezas têm sido realizados em diversos laboratórios. Dentre os compostos naturais testados, vários extratos de plantas com atividade anti-Leishmania têm componentes classificados como terpenos (DO SOCORRO et al, 2003)

\subsection{Terpenos}

Os terpenos são compostos isoprênicos encontrados em uma variedade de plantas, especialmente em frutas, vegetais e óleos. Estes são classificados de acordo com o número de unidades isoprênicas: temos assim hemiterpenos (C5, 1 unidade isoprênica), monoterpenos (C10,2 unidades isoprênicas), sesquisterpenos (C15, 3 unidades isoprênicas) e politerpenos (C5)n . Em plantas, diversos terpenos têm funções que vão desde a defesa contra microrganismos até papeis funcionais. São também responsáveis pelo cheiro característico de algumas plantas (MCGARVEY; CROTEAU, 2005).

Terpenos são produtos derivados da via de síntese de isoprenóides. As unidades isoprênicas são sintetizadas através da vía do mevalonato (MVA) em animais, fungos e arquebactérias (MCTAGGART, 2006) e pela via do metileritritol 
fosfato (MEP) em eubactérias e Plasmodium falciparum (JOMAA et al., 1999). Ambas as vias metabólicas são utilizadas em plantas (DUBEY et al., 2003).

Na via MVA ou via clássica, a polimerização de acetil-coenzima A (CoA) dá origem a hidroximetil glutaril CoA (HMG-CoA), que é reduzida por duas moléculas de NADPH formando ácido mevalônico. A via MEP, ou via alternativa resulta da condensão de gliceraldeído fosfato com piruvato formando deoxixilulose fosfato (DOXP) que é transformada a metileritritol fosfato (MEP). Ambas as vias vão formar isopentenil pirofosfato (IPP) e seu isômero dimetilalil pirofosfato (DMAPP), também chamados unidades isoprênicas. Das condensações sucessivas de IPP e DMAPP derivam o geranil pirofosfato (GPP), farnesil pirofosfato (FPP) e geranilgeranil pirofosfato (GGPP) (ROHMER, 1999). Preniltransferases são então encarregadas da elongação das cadeias isoprênicas, dando origem a compostos como dolicóis e cadeia lateral das ubiquinonas, enquanto a ciclização de polímeros isoprênicos de 6 unidades dá origem à via de síntese de esteróis. O FPP e GGPP são também utilizados em um importante tipo de modificação pós-traducional de proteínas, a isoprenilação.

Os esteróis são compostos imprescindíveis para a viabilidade celular como principais componentes de membrana: são representados por colesterol e ergosterol em animais (HART et al., 1989), ergosterol em parasitas e fungos (BERMAN et al., 1984) e campisterol, sinosterol e estigmasterol em plantas (SCHALLER, 2004).

Os dolicóis, compostos de longas cadeias isoprênicas, participam da transferência de oligossacarídeos na $\mathrm{N}$-glicosilação de proteínas, servindo como âncora, a qual é reciclada depois da traslocacão do açúcar para a proteína (VOET; VOET, 1995). 
Outro composto isoprênico importante é a ubiquinona, também conhecida como Coenzima $Q$, que participa da cadeia respiratória como transportador de elétrons e de íons na mitocôndria (ALBERTS et al., 1998), descrita em animais (SIEMIENIUK; SKRZYDLEWSKA, 2005), bactérias (MEGANATHAN, 2001) e parasitas. Em plantas apresenta-se como plastoquinona (ELLIS et al., 1994; RANGANATHAN; MUKKADA, 1995).

A isoprenilacão é uma das modificações pós-traducionais de proteínas reconhecida como a chave de vários de processos fisiológicos (LOBELL, 1998). Ocorre em todos os organismos vivos, afetando de 0,5 a 2,0\% das proteínas celulares e cumprindo importante função na ancoragem das proteínas de membrana (CASEY; SEABRA, 1996; CASEY et al., 1989).

Este processo se dá pela adição covalente de FPP ou GGPP via ligação tioester ao resíduo de cisteína (ZHANG; CASEY, 1996). Em eucariotos superiores foram identificadas três enzimas responsáveis pela isoprenilação: proteína farnesil transferase (PFTase) e duas geranil-geraniltransferases (PGGTase I e II), que catalisam os processos de farnesilacão e geranil-geranilacão de proteínas, respectivamente (GRUNLER et al., 1994; HARRIS; POULTER, 2000).

A PFTase transfere o grupo farnesil do FPP para uma cisteína na extremidade carboxiterminal da proteína reconhecendo o motivo CaaX, onde "a" freqüentemente representa um resíduo alifático e $X$ representa serina, metionina, alanina, glutamina ou cisteína (REISS et al., 1992; ROSKOSKI, 2003). A PGGTase-I faz a transferência do grupo geranilgeranil do GGPP à cisteína do motivo terminal CaaL onde L é uma leucina (CASEY; SEABRA, 1996), enquanto PGGT-II transfere grupos geranilgeranil a proteínas com seqüências carboxiterminal CXC, XCC, CCXX e CCX (PEREIRA-LEAL et al., 2001). 
Estas enzimas preniltransferases são diméricas, tendo a mesma subunidade á, mas possuem diferentes subunidades $\beta$ (GRUNLER et al., 1994). A PFTase foi a primeira a ser identificada e caracterizada seguida pelas enzimas PGGTase-I e PGGTase-II, sendo que a última apresenta $30 \%$ de similaridade com as duas primeiras (LEUNG et al., 2006).

Muitas proteínas isopreniladas pertencem ao grupo das pequenas G proteínas (PGP) e estão envolvidas em uma variedade de sinais relativos ao crescimento e diferenciação celular, organização do citoesqueleto e transporte intravesicular. Estas funções das PGP dependem da modificação pós-traducional (MCTAGGART, 2006), que resulta na adesão de grupos prenil que as ancoram às membranas intracelulares (MAGEE; MARSHALL, 1999).

As PGP são proteínas monoméricas, que compreendem a superfamília Ras, que por sua vez inclui famílias estruturalmente classificadas: Ras, Rho/Rac, Rab, Sar1/Arf e Ran (BUSS et al., 1991). São farnesiladas por PFTase a família Ras e lâmina nuclear, entre outras (INGLESE et al., 1992; JAMES et al., 1994), que participam das cascatas de transdução de sinal regulando a sobrevivência, proliferação e diferenciação das células (VOJTEK; DER, 1998). São geraniladas por PGGTase-I as famílias Rho/Rac, Sar1/Arf e Ran, implicadas na regulação do citoesqueleto, matriz extracelular, morfologia, crescimento, e migrações celulares (VAN; SOUZA, 1997). PGGT-II tem quase exclusivamente as proteínas Rab como substrato, encarregadas do transporte vesicular (PEREIRA-LEAL; SEABRA, 2000).

Dentro da família Ras está a P21 Ras, amplamente expressa em numerosos tecidos e ativada por um número de fatores polipeptídicos e sinais extracelulares: peptídeos de crescimento, citocinas e hormônios (JACKSON et al., 1990; VOJTEK; DER, 1998). A alteração da P21 Ras produz mutantes nos quais esta proteína está 
constantemente ativada, resultando em alteração na regulação do crescimento. Tais aberrações ocorrem em 10- 15\% de todos os cânceres humanos (BARBACID, 1987).

A prenilacão de proteínas foi descrita tanto em procariotos como em eucariotos e foi recentemente demonstrada em parasitas como Giardia lambia (LUJÁN et al., 1995), Schistosoma mansoni (CHEN; BENNETT, 1993) e Trypanosoma brucei (FIELD et al., 1996; YOKOYAMA et al., 1997). Proteínas isopreniladas foram também detectadas em Trypanosoma cruzi (OZ et al., 1994), Leishmania donovani (CASSEL et al., 1991) e Plasmodium falciparum (MOURA et al., 2001; RODRIGUES-GOULART et al., 2004).

A investigação da isoprenilação das PGP em parasitas abriu um campo bastante amplo de investigação, sendo um alvo potencial para o desenvolvimento de novas drogas, já que a inibição na síntese ou modificação dessas proteínas deve interferir na sinalização de mensagens de crescimento e diferenciação celular, o que levará a uma desorganização interna da célula e posteriormente a morte.

Em plantas, os derivados isoprênicos obtidos através das vias do MVA e MEP nos seus diferentes compartimentos intracelulares, cumprem diversos papéis funcionais como: hormônios (giberinas), pigmentos fotossintéticos (fitol), carregadores de elétrons (plastoquinone), componentes de membrana (fitosterol), servindo também para a comunicação e defesa (HARBORNE, 1990). Dentre os produtos da via de síntese de isoprenóides em plantas estão também os terpenos.

Os terpenos se assemelham estruturalmente a alguns intermediários da via do MVA em animais, fungos e parasitas e, portanto, podem interferir em vários pontos desta, inibindo a síntese de esteróis e bloqueando a isoprenilação de 
proteínas (CROWELL et al., 1991; CROWELL; GOULD, 1994). Estes isoprenóides de plantas são capazes de interferir em outros mecanismos celulares como inibição ou indução de enzimas, capacidade antioxidante e seqüestro de metabólitos reativos (DRAGSTED et al., 1997).

Atividade bacteriana, antifúngica e antiparasitária tem sido demonstrada para vários terpenos (MOURA et al., 2001; ZUNIGA et al., 2005). O linalool demonstrou ter atividade contra L. (L.) amazonensis nas formas promastigota e amastigotas além de estimular a produção de óxido nítrico em macrófagos (DO SOCORRO et al., 2003). Já nerolidol inibe o crescimento de culturas de promastigotas e amastigotas de várias espécies de Leishmania, sendo um inibidor da síntese de FPP (ARRUDA et al., 2005).

O limoneno é um monoterpeno presente em cascas de frutos cítricos, principalmente de limão e laranja, sendo usado na indústria alimentícia e de cosméticos como agente aromatizante. O limoneno tem atividade quimiopreventiva e quimioterapêutica contra vários tipos de tumores, além de ser um composto de baixa toxicidade (BROITMAN et al., 1996). Os mecanismos de ação do limoneno propostos contra tumorigênese incluem interferência na isoprenilação proteínas por inibição das enzimas PFTase e PGGTase I e II (CROWELL et al., 1991; CROWELL; GOULD, 1994), inibição de síntese de pequenas proteínas G (CHEN et al., 1999), inibição da enzima HMG-CoA redutase (PEFFLEY; GAYEN, 2003) e indução da morte programada por apoptose.

A atividade do limoneno inibindo os diferentes tipos de câncer ou no tratamento de tumores já instalados foi demonstrada em modelos experimentais de câncer de mama e pâncreas (BROITMAN et al., 1996; HE et al., 1997; CROWELL, 
1997). Este composto foi utilizado em pacientes com câncer avançado mostrando boa tolerância e respostas parciais (VIGUSHIN et al., 1998).

A atividade de limoneno também foi demonstrada contra parasitas como $T$. cruzi, sendo desconhecido o mecanismo de ação (KIUCHI et al., 2002) e $P$. falciparum parecendo interferir na síntese de ubiquinona, dolicol e isoprenilação de proteínas (MOURA et al., 2001; RODRIGUES-GOULART et al., 2004).

Estudos realizados em nosso laboratório demonstraram que o limoneno é tóxico para promastigotas e amastigotas de Leishmania cultivados in vitro. $\mathrm{O}$ limoneno é também ativo na redução do parasitismo intracelular em macrófagos e tem atividade terapêutica significativa in vivo, em modelo experimental (ARRUDA, 2007). O mecanismo de ação do limoneno contra Leishmania parece estar relacionado à inibição da enzima HMG-CoA redutase (ARRUDA; ULIANA, dados não publicados).

Limoneno é metabolizado no fígado por uma variedade de espécies de mamíferos, sendo transformado em álcool perílico, aldeído perílico e finalmente ácido perílico (CROWELL; GOULD, 1994) (Fig. 1). Esses compostos são também encontrados em plantas como lavanda, hortela, salvia entre outras. Metabólitos do limoneno demonstraram ser mais eficientes que o limoneno frente a diferentes células cancerígenas. Mostrou-se, por exemplo, que álcool perílico é um inibidor mais potente que limoneno no tratamento de tumores de mama, produzindo efeitos no crescimento, progressão do ciclo celular e regulação e expressão de proteínas (YURI et al., 2004). Estudos farmacocinéticos indicaram que o álcool perílico está sujeito a uma rápida absorção pelo trato gastrointestinal, sendo metabolizado a ácido perílico (HAAG; GOULD, 1994; RIPPLE et al., 2000; CHEN et al., 1998). 


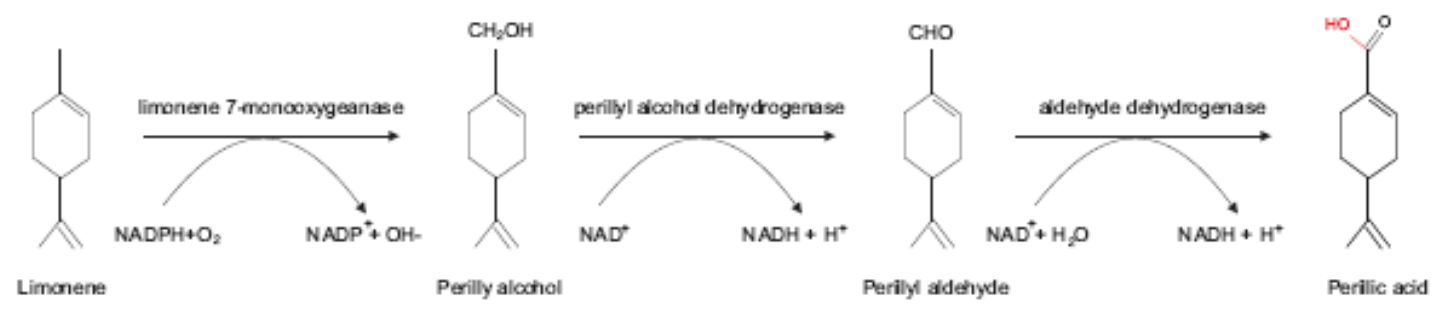

Figura 1 - Estrutura do limoneno e seus derivados

De fato, o ácido perílico foi identificado como um dos maiores metabólitos biológicos do limoneno e do álcool perílico em humanos, funcionando como um potente inibidor das enzimas de isoprenilacão (GELB et al., 1995; REN et al., 1997; VIGUSHIN et al., 1998; CERDA et al., 1999; CHOW et al., 2002), com conseqüente redução na farnesilação das proteínas Ras.

Também foi demonstrado que o ácido perílico desencadeia a morte celular por apoptose, é supressor substancial da produção de IL-2 e IL-10 (SCHULZ et al., 1994). Esta droga tem a capacidade de depletar tanto a farnesilação como a geranilação de pequenas proteínas G (SCHULZ et al., 1994) sendo um potente inibidor do crescimento celular (CROWELL; GOULD, 1994) bloqueando a progressão do ciclo celular em G0/G1 (FERRI et al., 2001). Ácido perílico inibe a formação do nódulo no tumor por células de melanoma (RAPHAEL; G., 2003). Recentemente foi demonstrado que ácido perílico inibe a farnesilação das proteínas Ras por mecanismos não relacionados a PFTase (SCHULZ et al., 1994).

Considerando-se a atividade leishmanicida demonstrada do limoneno e baseandonos nas observações demonstrando a maior atividade dos metabólitos do limoneno na inibição do crescimento de células tumorais, consideramos interessante avaliar a atividade de álcool perílico, aldeído perílico e ácido perílico como possíveis drogas contra Leishmania. 


\section{OBJETIVOS}

\subsection{Gerais}

Testar a atividade de álcool perílico, aldeído perílico e ácido perílico contra Leishmania sp.

\subsection{Específicos}

- Testar a atividade de álcool perílico, aldeído perílico e ácido perílico contra promastigotas de L. (L.) major e L. (L.) amazonensis.

- Testar a citotoxicidade desses compostos em culturas de macrófagos e fibroblasto.

- Testar atividade do álcool perílico, aldeído perílico e ácido perílico contra amastigotas extraídos de lesão.

- Testar a atividade do álcool perílico, aldeído perílico e ácido perílico contra amastigotas intracelulares.

- Testar os compostos com atividade in vitro, isolados ou em associações, no tratamento de camundongos infectados com L. (L.) amazonensis e L. (L.) major. 


\section{MATERIAIS E MÉTODOS}

\subsection{Parasitas}

Formas promastigotas de L. (L.) major (MHOM/LL/81/Friedlin) e L. (L.) amazonensis (MHOM/BR/73/M2269) foram cultivadas em meio 199 (Gibco-BRL), suplementado com $10 \%$ de soro fetal bovino (SFB). As culturas foram mantidas em estufa a $25^{\circ} \mathrm{C}$.

Para a obtenção de amastigotas de lesão, camundongos BALB/c foram infectados por via subcutânea no coxim plantar com $1 \times 10^{6}$ promastigotas de $L$. (L.) amazonensis (ULIANA et al., 1999). Os animais foram sacrificados após 12 semanas e o material da lesão foi homogeneizado e lavado com PBS $(2,6 \mathrm{mM}$ $\mathrm{NaH} 2 \mathrm{PO} 4,7,4 \mathrm{mM}$ de Na2HPO $4,14 \mathrm{mM} \mathrm{NaCl}, \mathrm{pH}$ 7.2). Os debris celulares foram separados por centrifugação a $60 \mathrm{xg}$ por 8 minutos. O sobrenadante foi recolhido e lavado 3 vezes com PBS estéril a $600 \mathrm{xg}$ por 10 minutos. O precipitado foi ressuspenso em $5 \mathrm{~mL}$ de PBS e passado numa seringa com agulha 25G. Os amastigotas foram mantidos in vitro em meio RPMI-1640 completo, preparado diluindo-se o meio liofilizado em água e adicionando-se $2 \mu \mathrm{M}$ de $\beta$-mercaptoetanol, $25 \mathrm{mM}$ HEPES, $2,7 \mathrm{mM} \mathrm{NaHCO} 3$ e $10 \%$ SFB. Também foram acrescidos ao meio $100 \mu \mathrm{g} / \mathrm{mL}$ de ampicilina e $50 \mu \mathrm{g} / \mathrm{mL}$ gentamicina. As culturas foram mantidas em estufa a $33{ }^{\circ} \mathrm{C}$ com atmosfera de $5 \%$ de $\mathrm{CO}_{2}$. A concentração de parasitas foi determinada por contagem em câmara de Neubauer. 


\subsection{Terpenos}

Os terpenos, (S)-(-)-álcool perílico, 96\%, (-)-aldeído perílico, 92\%, e (S)-(-)ácido perílico, 95\%, foram adquiridos do Sigma-Aldrich. A cada experimento foram preparadas soluções estoque para serem utilizadas na hora. Os terpenos foram diluídos em etanol para os ensaios in vitro.

\subsection{Linhagens celulares}

Para testar a toxicidade de álcool e ácido perílico em culturas celulares de mamíferos foram utilizadas as linhagens de macrófagos J774. $\mathrm{A}_{1}$ e de fibroblastos HFF. As culturas celulares foram mantidas em meio RPMI-1640 completo em estufa a $37^{\circ} \mathrm{C}$ com atmosfera ao $5 \% \mathrm{CO}_{2}$.

\subsection{Camundongos BALB/c}

Os camundongos BALB/c fêmeas com aproximadamente 4 semanas de idade, foram adquiridos do biotério do Departamento de Parasitologia (ICB - USP).

\subsection{Obtenção de macrófagos residentes de peritônio}

Foram sacrificadas fêmeas de camundongos BALB/c em câmara de $\mathrm{CO}_{2}$. Cada animal teve o abdomen exposto para inoculação de $4 \mathrm{~mL}$ de meio RPMI1640 gelado na cavidade abdominal. Foram extraídos $3 \mathrm{~mL}$ de conteúdo da cavidade. O procedimento foi repetido quatro vezes. O material recolhido foi mantido em gelo. A suspensão de células coletadas foi centrifugada a $300 \mathrm{xg}$ por 10 min e lavadas com PBS gelado por 3 vezes. Após a lavagem, as células obtidas foram contadas e plaqueadas. 


\subsection{Inibição de crescimento de promastigotas e amastigotas de Leishmania sp. na presença de álcool, aldeído e ácido perílico}

As culturas de promastigotas de L. (L.) major e L. (L.) amazonensis, iniciadas com inoculo de $1 \times 10^{7}$ células $/ \mathrm{mL}$ para $2 \mathrm{~h}$ e $2 \times 10^{6}$ células por $/ \mathrm{mL}$ para 24 e $48 \mathrm{~h}$, respectivamente, foram tratadas com diversas concentrações de álcool perílico, aldeído perílico e ácido perílico. As culturas de amastigotas de L. (L.) amazonensis purificados de lesão foram iniciadas com inóculo de $5 \times 10^{6}$ células $/ \mathrm{mL}$ e incubadas por $24 \mathrm{~h}$ na presença das diversas concentrações das drogas. As culturas foram incubadas em placas de 24 poços e a viabilidade das células foi avaliada utilizando-se o teste do MTT. Culturas mantidas em meio sem droga e incubadas na presença do diluente da droga serviram como controles experimentais. Os resultados dos testes de inibição do crescimento foram expressos calculando-se a porcentagem de sobrevivência dos parasitas após tratamento em relação ao grupo controle que não recebeu droga. Calculou-se também o valor referente a $I_{50} \mathrm{a}$ partir do programa estatístico "Data analysis and technical graphics - Origin 6.1". Os experimentos foram realizados em triplicata e repetidos pelo menos duas vezes.

\subsection{Teste do MTT}

Após o período de incubação na presença de concentrações crescentes de drogas, as culturas foram centrifugadas a $1000 \mathrm{xg}$ por 5 minutos. O sobrenadante foi desprezado e as células lavadas com $1 \mathrm{~mL}$ de "tampão A" (116 mM NaCl; 5,4 mM $\mathrm{KCl} ; 0,8 \mathrm{mM} \mathrm{MgSO} 4 ; 5,5 \mathrm{mM}$ glicose; $10 \mathrm{mM}$ MOPS; $\mathrm{pH}$ 7,2). Depois da centrifugação a 1000 xg por 5 minutos, o precipitado foi ressuspenso em $100 \mu \mathrm{L}$ de "tampão A" e $20 \mu \mathrm{L}$ de MTT (3-(4,5-dimetiltiazol- 2-il)-2,5 difenil bromo tetrazolium) 
(5 mg/mL em tampão A) e incubado por duas horas a $25{ }^{\circ} \mathrm{C}$. A reação foi interrompida pela adição de $200 \mu \mathrm{L}$ de SDS $10 \%$. A leitura foi realizada em um leitor de ELISA, medindo-se a absorbância a $595 \mathrm{~nm}$ sendo $690 \mathrm{~nm}$ o comprimento de onda utilizado como referência. A mitocôndria do parasita vivo converte o MTT em um produto corado denominado formazan, capaz de ser medido espectrofotometricamente.

3.8 Teste de citotoxicidade das linhagens celulares na presença de álcool, aldeído e ácido perílico

Para avaliar a toxicidade das drogas, culturas de macrófagos J774.A macrófagos de peritônio e fibroblastos HFF, iniciadas com inoculo de $5 \times 10^{5}$ células $/ \mathrm{mL}$ foram incubadas com álcool, aldeído e ácido perílico em diferentes concentrações por $24 \mathrm{~h}$. Após este período, as células aderidas foram lavadas com $1 \mathrm{~mL}$ de tampão A. Aos poços contendo as células foi adicionado $200 \mu \mathrm{L}$ de tampão A e $40 \mu \mathrm{L}$ de MTT $5 \mathrm{mg} / \mathrm{mL}$. As culturas foram incubadas por $2 \mathrm{~h}$ a $37^{\circ} \mathrm{C}$. A reação foi interrompida pela adição de $100 \mu \mathrm{L}$ de SDS 20\%. A absorbância foi medida como descrito acima e a porcentagem de células viáveis foi calculada em relação ao controle cultivado na ausência de droga.

\subsection{Inibição de crescimento de amastigotas intracelulares}

Tanto os macrófagos J774.A 1 quanto os macrófagos extraídos de peritônio de camundongos foram cultivados em placas de 24 orifícios contendo lamínulas de 13 $\mathrm{mm}$ de diâmetro. Cada lamínula recebeu $4 \times 10^{5}$ macrófagos que foram cultivados durante 16 horas a $37{ }^{\circ} \mathrm{C}$ em estufa com atmosfera de $5 \%$ de $\mathrm{CO} 2$ para se aderirem. Após esse período os macrófagos foram infectados com promastigotas 
de L. (L.) major de fase estacionária de cultura em uma proporção de 15:1 parasitas por macrófago durante 3 horas a $33^{\circ} \mathrm{C}$. Os compostos a serem testados foram adicionados ao meio de cultura. Após $24 \mathrm{~h}$ o meio foi trocado e a droga foi novamente aplicada nas mesmas concentrações iniciais. Após $48 \mathrm{~h}$ desde a infecção, a cultura foi novamente lavada com RPMI sem soro a $37^{\circ} \mathrm{C}$ e as células. Foram fixadas com metanol por 1 minuto e coradas com o conjunto de corantes Instant Prov (Newprov) e observadas em microscópio óptico.

\subsection{Quantificação de óxido nítrico (NO) por reação de Griess.}

Alternativamente, culturas de macrófagos foram submetidas a um prétratamento de álcool perílico ou aldeído perílico por 24 e 48h, seguido da infecção com promastigotas de L. (L.) major como descrito acima. As células infectadas foram mantidas em cultura na presença das drogas por 24 ou $48 \mathrm{~h}$ e a seguir processadas como descrito. Para o cálculo da porcentagem de inibição do crescimento de amastigotas intracelulares foram calculadas as médias de três experimentos realizados em triplicata e em cada triplicata foram contadas 100 células.

Para avaliar a produção de NO em culturas celulares foi utilizada a Reação de Griess que avalia a produção de nitrito, produto de degradação de NO (DING et al., 1990).

As células macrofágicas utilizadas para testar a inibição de crescimento de amastigotas intracelulares tiveram o sobrenadante colhido, após 24 e 48h, e congelado para a realização da reação de Griess.

Para a quantificação de NO, foram adicionados $50 \mu \mathrm{L}$ de sobrenadante das culturas (em placas de 96 cavidades)a $100 \mu \mathrm{L}$ do reagente de Griess, contendo 50 
$\mu L$ de solução $A$ (sulfanilamida $1 \%$ ) e $50 \mu \mathrm{L}$ de solução $B$ (dihidrocloreto de naphtilenodiamino (NAP)0,1\% (v/v) em 5\% de $\mathrm{H}_{3} \mathrm{PO} 4$ ), incubando-se a reação durante 10 minutos a temperatura ambiente. Para a determinação da concentração de nitrito foi utilizado $\mathrm{NaNO}_{3}$ como padrão com concentração inicial de $100 \mu \mathrm{M}$. A leitura das densidades ópticas foi realizada em leitor de ELISA com filtro de 550 $\mathrm{nm}$.

\subsection{Preparações de toxicidade de álcool e aldeído perílico para uso in vivo}

Nos ensaios in vivo, os terpenos administrados por via tópica foram preparados em solução de $50 \%$ de droga com $50 \%$ de etanol ao um volume final de $10 \mu \mathrm{L}$ e $20 \mu \mathrm{L}(0,25 \mathrm{~g} / \mathrm{kg}$ e $0,5 \mathrm{~g} / \mathrm{kg}$ respectivamente), ou creme Lanette $\mathrm{N}$ (álcool ceto estearílico) contendo 10\% álcool perílico, 10\% aldeído perílico ou uma mistura contendo álcool e aldeído perílico $10 \%$ cada. O creme foi utilizado até 21 dias após a preparação, sendo mantido a $4{ }^{\circ} \mathrm{C}$. Para administração intra-retal foi utilizada uma solução de $50 \%$ de álcool ou aldeído perílico $(0,5 \mathrm{~g} / \mathrm{kg}), 5 \%$ de etanol e $45 \%$ de PBS para alcançar um volume final de $20 \mu \mathrm{L}$. Para a via intraperitoneal foi utilizado uma solução de $10 \%(0,25 \mathrm{~g} / \mathrm{kg})$ de droga em $90 \%$ PBS a um volume máximo de $50 \mu \mathrm{L}$

Grupos de 5 camundongos BALB/c foram utilizados para teste de toxicidade da droga. Um grupo controle não tratado foi mantido em paralelo para observação do comportamento dos animais. O tratamento foi realizado por 2 semanas por via tópica ou intra-retal e foram observados o comportamento e reação dérmica frente ao álcool perílico e aldeído perílico desde o início do teste até a 2a semana. Posteriormente se fez um seguimento após o tratamento por 4 semanas em ambos casos. 


\subsection{Teste de atividade de álcool e aldeído perílico em camundongos infectados com Leishmania sp}

Grupos de 5 camundongos BALB/c foram inoculados com $1 \times 10^{6}$ amastigotas

de $L$. (L.) amazonensis ou $2 \times 10^{6}$ amastigotas de $L$. (L.) major, na base da cauda. $O$ tratamento foi iniciado 15 após a infecção como L. (L.) amazonensis e 21 dias para L. (L.) major. Em cada experimento foram incluídos um grupo controle não tratado e um grupo que recebeu apenas o veículo utilizado para a preparação do creme de uso tópico. Os esquemas e vias utilizadas para o tratamento foram: a) via tópica (em creme Lanette) de duas a três vezes ao dia por 3 semanas; b) via intra retal uma ou duas vezes por dia por 2 - 3 semanas; c) via intra peritonial uma vez por dia por 3 semanas. O diâmetro da cauda foi medido a cada 7 dias desde o início do tratamento até a $7^{a}$ ou $10^{a}$ semana. Após este período os animais foram sacrificados.

\subsection{Marcação metabólica com metionina}

Promastigotas $\left(6,3 \times 10^{6} / \mathrm{mL}\right)$ ou amastigotas $\left(2 \times 10^{8} / \mathrm{mL}\right)$ de L. (L.) amazonensis, lavados 3 vezes com PBS, foram pré-incubados em meio deficiente em metionina ( $1,5 \mathrm{mg} / \mathrm{L})$ por 1 hora. Ao final deste período foram adicionados $2 \mu \mathrm{Ci}$ de $\left[{ }^{35} \mathrm{~S}\right]$-metionina (> $1000 \mathrm{Ci} / \mathrm{mmol}$, Amersham) e as culturas foram tratadas e incubadas com as diferentes concentrações de álcool, aldeído e ácido perílico por 24 horas a $25{ }^{\circ} \mathrm{C}$. Os parasitas foram então submetidos a 3 lavagens com $10 \mathrm{~mL}$ de PBS e os parasitas coletados foram ressuspensos no volume de PBS restante no tubo após a última lavagem. 
As células foram lisadas com o mesmo volume de tampão de lise (Tris 10 mM, pH 7,6, NaCl 150 mM, 2\% de NP-40, PMSF 200 mM, benzamidina 2 mM, leupeptina $10 \mathrm{mM}$, fenantrolina $5 \mathrm{mM}$ e inibidor de tripsina $50 \mathrm{mg} / \mathrm{mL}$ ). A suspensão foi vortexada e fervida por 10 minutos, mantida no gelo por 10 minutos e centrifugada a 10.000 xg por 10 minutos. Foi acrescentado 1 volume de tampão de amostra $2 \mathrm{X}$ (Tris $50 \mathrm{mM} \mathrm{pH=6,8,} \mathrm{SDS} \mathrm{2 \% ,} \mathrm{glicerol} \mathrm{10 \% ,} \beta$-mercaptoetanol $5 \%$, azul de bromofenol 0,1\%). O extrato foi centrifugado novamente a $10.000 \mathrm{xg}$ por 10 minutos e o sobrenadante adicionado ao gel.

\subsection{Eletroforese de proteínas}

A separação eletroforética foi realizada em gel de acrilamida a $12 \%$ na presença de SDS 0,1\% como descrito por Laemmli (1970). A separação foi efetuada a $100 \mathrm{~V}$ em tampão Tris-glicina (Tris 0,025 M, pH 8,3, glicina 0,19 M e SDS $0,1 \%$ ). Foi utilizado o marcador de alto peso molecular (Invitrogen) como padrão de peso molecular de proteínas. Após a corrida o gel foi corado com azul de Coomassie (coomassie blue 0,05\%, metanol 45\%, acido acético 10\%). Em seguida o gel foi descorado em solução de etanol $23 \%$, acido acético $7 \%$ e tratado com Amplify (Amershan) por 40 minutos e exposto a autoradiografia por 1 semana.

\subsection{Análise de isoprenilação de proteínas.}

Promastigotas (1 a $2 \times 10^{8} / \mathrm{mL}$ ) de L. (L.) amazonensis foram tratados por $24 \mathrm{~h}$ com diferentes concentrações de álcool, aldeído e ácido perílico e marcados com 8 $\mu \mathrm{Ci} / \mathrm{mL}$ de [1(n)- 3H]-farnesil pirofosfato (17 Ci/mmol; Amersham) ou $15 \mu \mathrm{Ci} / \mathrm{mL}$ de [1(n)-3H]-geranilgeranil pirofosfato (15 Ci/mmol, Amersham) por $20-22 \mathrm{~h}$ a $25{ }^{\circ} \mathrm{C}$. Os extratos protéicos e a separação das proteínas foram realizados em gel de 
acrilamida 12 ou $15 \%$ como descritos nos itens anteriores e o tempo de exposição foi 2 meses.

\subsection{Análise estatística}

Os dados obtidos em experimentos in vitro do tratamento de macrófagos infectados e experimentos in vivo foram submetidos a análise pelo teste $t$ de Student para amostras pareadas considerando-se as diferenças significativas quando $P<0,05$. 


\section{RESULTADOS}

\subsection{Determinação da atividade dos derivados do limoneno in vitro}

4.1.1 Atividade dos derivados do limoneno e cálculo da concentração inibitória $50 \%\left(\mathrm{IC}_{50}\right)$ para promastigotas de $L$. (L.) major e $L$. (L.) amazonensis

Para testar a atividade de álcool, aldeído e ácido perílico na sobrevivência de promastigotas e calcular $\mathrm{o}$ valor da $\mathrm{IC}_{50}$ foram realizados experimentos in vitro incubando-se culturas de promastigotas durante tempos de 2, 24 e 48 horas com concentrações crescentes das drogas. A verificação da porcentagem de células sobreviventes foi obtida pelo teste de MTT.

Como os derivados do limoneno foram diluídos em etanol, utilizamos o mesmo como controle. Promastigotas foram incubados com o volume de etanol correspondente ao volume utilizado para o teste de máxima concentração (1\% do volume total). Esta cultura não apresentou alterações significativas na porcentagem de células sobreviventes após a incubação, o que permite afirmar que o etanol, no volume utilizado, não interfere na sobrevivência dos parasitas.

\subsubsection{Atividade de álcool perílico contra promastigotas}

A atividade de álcool perílico contra promastigotas de L. (L.) major foi avaliada em concentrações variando de 0,1 a 5,0 mM. Observamos efeito mesmo com tempos curtos de incubação de 2 horas, mas a atividade foi mais acentuada quando os parasitas foram mantidos na presença da droga por 24 e 48 horas (Fig.2A) 
O efeito leishmanicida do álcool perílico foi também testado contra promastigotas de L. (L.) amazonensis (Fig. 2B). Para essa espécie, o efeito foi mais intenso do que o observado contra $L$. (L.) major em tempos curtos de incubação (2 horas), especialmente nas concentrações mais baixas de droga.

Nos tempos de 24 e 48 horas de incubação nas duas espécies avaliadas a atividade de álcool perílico foi semelhante a partir de concentrações superiores a 1 $\mathrm{mM}$.

Atividade máxima foi obtida depois de 48 horas de incubação com valores de $I_{50}$ de 0,29 e 0,48 mM para $L$. (L.) major e $L$. (L.) amazonensis, respectivamente (Tabelas 1 e 2).

\subsubsection{Atividade de aldeído perílico contra promastigotas}

Verificamos que o tratamento com aldeído perílico em concentrações variando de 0,01 a 0,50 mM induziram redução da sobrevivência de promastigotas de L. (L.) major. Após 2 horas de incubação a droga foi pouco ativa, mesmo nas concentrações mais elevadas.

Entretanto, tempos de incubação de 24 e 48 horas resultaram em viabilidade diminuída (Fig. 3A). Constatamos também que culturas de L. (L.) amazonensis que foram incubadas por 2, 24 e 48 horas com aldeído perílico tiveram sua multiplicação inibida (Fig. 3B).

Assim como observado com álcool perílico, promastigotas de L. (L.) amazonensis tratadas com aldeído perílico também se mostraram mais sensíveis à incubação com a droga em tempos curtos de incubação. 
Tabela 1 - $\mathrm{IC}_{50}$ de promastigotas de L. (L.) major tratadas com álcool perílico, aldeído perílico e ácido perílico.

\begin{tabular}{c|c|c|c}
$\mathbf{I C}_{\mathbf{5 0}}(\mathbf{m M})$ & Álcool perílico & Aldeído perílico & Ácido perílico \\
\hline $\mathbf{2 h}$ & $2,09 \pm 0,02$ & $\mathrm{NC}^{\mathrm{a}}$ & $\mathrm{NC}^{\mathrm{b}}$ \\
\hline $\mathbf{2 4 h}$ & $0,72 \pm 0,04$ & $0.11 \pm 0,02$ & $0,70 \pm 0,23$ \\
\hline $\mathbf{4 8 h}$ & $0,29 \pm 0,04$ & $0,06 \pm 0,01$ & $1,11 \pm 0,08$
\end{tabular}

NC: Não calculado

$N C^{a}$ : Não foi possível calcular $I_{50}$ após 2 horas de incubação, período em que, com concentrações de $0,5 \mathrm{mM}$ de aldeído perílico, houve $75 \%$ de sobrevivência.

$N C^{b}$ : Não foi possível calcular $I_{50}$ após $2 \mathrm{~h}$ horas de incubação, período em que, com concentrações de $5.0 \mathrm{mM}$ de ácido perílico, houve $77 \%$ de sobrevivência.

Tabela 2 - $I C_{50}$ de promastigotas de L. (L.) amazonensis tratadas com álcool perílico, aldeído perílico e ácido perílico.

\begin{tabular}{c|c|c|c}
$\mathbf{I C}_{\mathbf{5 0}}(\mathbf{m M})$ & Álcool perílico & Aldeído perílico & Ácido perílico \\
\hline $\mathbf{2 h}$ & $1,23 \pm 0,12$ & $0,14 \pm 0,03$ & $\mathrm{NR}$ \\
\hline $\mathbf{2 4 h}$ & $0,90 \pm 0,08$ & $0,07 \pm 0,004$ & $\mathrm{NC}^{\mathrm{a}}$ \\
\hline $\mathbf{4 8 h}$ & $0,48 \pm 0,06$ & $0,10 \pm 0,01$ & $2,79 \pm 1,7$
\end{tabular}

NR. Experimento não realizado

$N C^{a}$ : Não foi possível calcular $I_{50}$ após $2 \mathrm{~h}$ horas de incubação, período em que nas concentrações de $5.0 \mathrm{mM}$ de ácido perílico houve $40 \%$ de sobrevivência. 


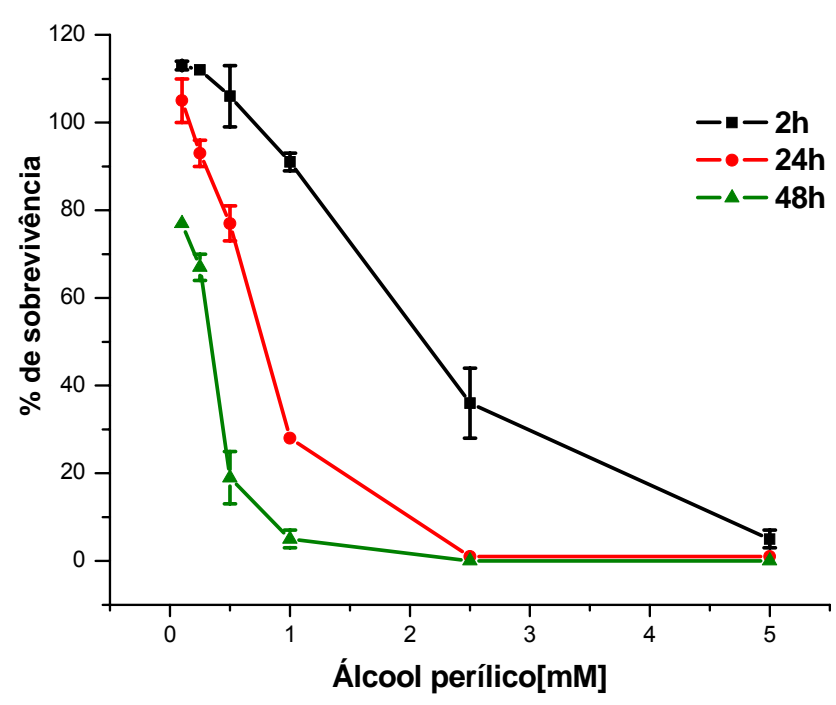

L. (L.) amazonensis - promastigotas

B

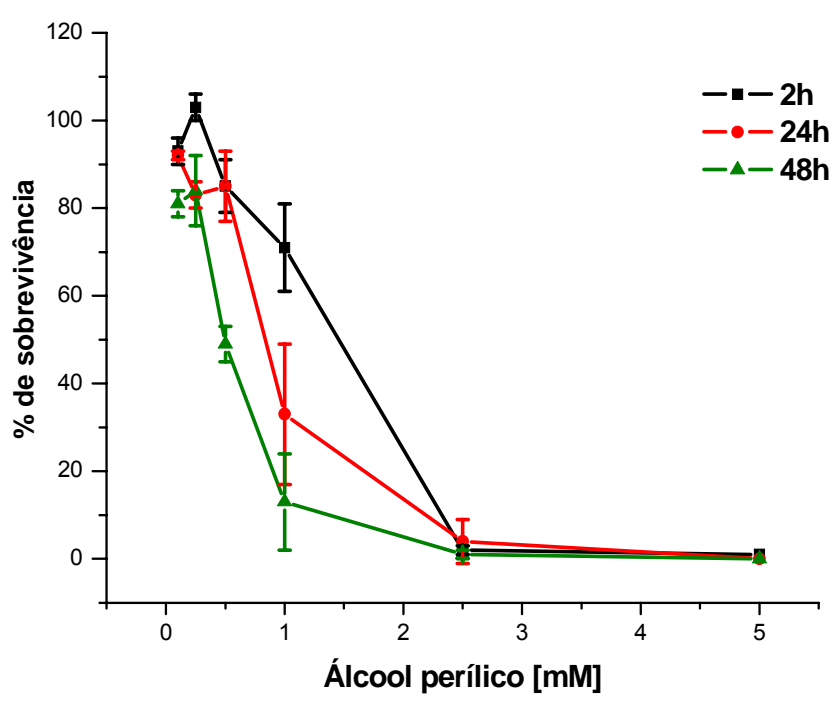

Figura 2 - Efeito do álcool perílico em culturas de promastigotas de $L$. (L.) major e $L$. (L.) amazonensis. Culturas de promastigotas foram incubadas com doses crescentes de álcool perílico por 2, 24 e 48 horas. A viabilidade das células foi avaliada por teste de MTT e a porcentagem de sobrevivência for calculada em relação às culturas não tratadas com a droga. (A) Efeito do álcool perílico em culturas de promastigotas de L. (L.) major. (B) Efeito do álcool perílico em culturas de promastigotas de L. (L.) amazonensis. 


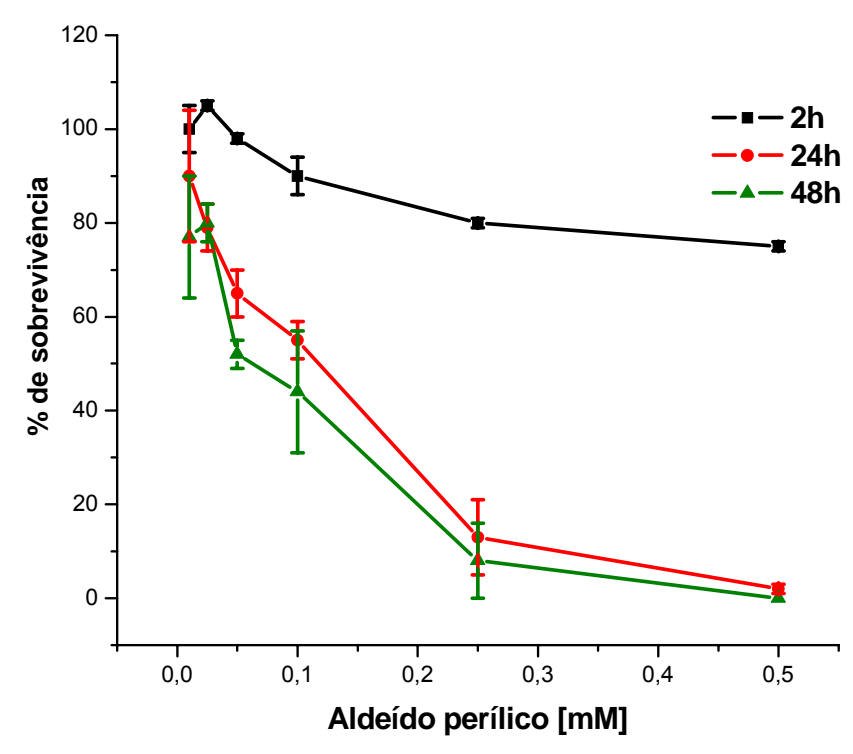

\section{L.(L.) amazonensis - promastigotas}

B

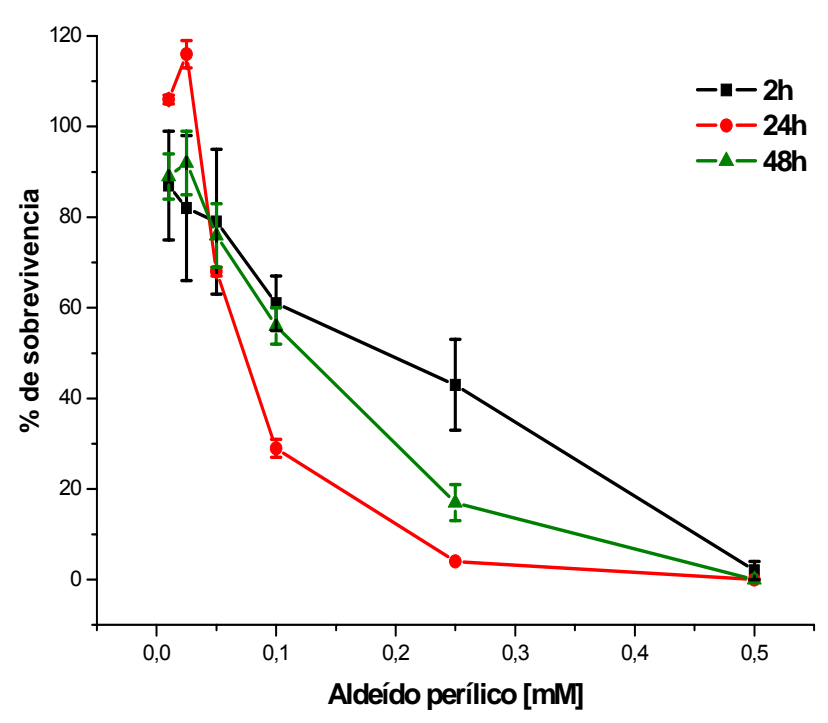

Figura 3. Efeito do aldeído perílico em culturas de promastigotas de $L$. (L.) major e $L$. (L.) amazonensis. Culturas de promastigotas foram incubadas com doses crescentes de aldeído perílico por 2, 24 e 48 horas. A viabilidade das células foi avaliada por MTT. (A) Promastigotas de L. (L.) major. (B) Promastigotas de $L$. (L.) amazonensis. 
Os valores de $\mathrm{IC}_{50}$ de aldeído perílico contra promastigotas de L. (L.) major e L. (L.) amazonensis após 48 horas de incubação foram de 0,06 e 0,10 mM, respectivamente (Tabelas 1 e 2 ).

\subsubsection{Atividade de ácido perílico contra promastigotas}

Culturas de promastigotas de L. (L.) major tratadas com ácido perílico em concentrações variando de 0,1 a 5,0 mM tiveram sua multiplicação inibida de forma dose-dependente.

Observamos efeitos apenas discretos após tempos de incubação de 2 horas. O efeito leishmanicida do ácido perílico contra L. (L.) major foi máximo após 24 horas, com $\mathrm{IC}_{50}$ de $0,70 \mathrm{mM}$ (Tabela 1), não se observando incremento da atividade em tempos mais longos de incubação (Fig. 4A).

O efeito do ácido perílico contra culturas de promastigotas de L. (L.) amazonensis após 24 e 48 horas de incubação foi menos intenso do que o observado contra L. (L.) major (Fig. 4B).

Concentrações máximas de 5.0 mM não inibiram totalmente a multiplicação nas duas espécies, mesmo após 48 horas (Fig. 4B). As $I_{50}$ calculadas para ácido perílico são apresentadas nas Tabelas 1 e 2.

\subsubsection{Determinação da atividade dos derivados do limoneno e cálculo de $\mathrm{IC}_{50}$ em amastigotas de $L$. (L.) amazonensis}

Culturas de amastigotas de L. (L.) amazonensis extraídos de lesão de camundongos BALB/C foram utilizados para testar a atividade dos derivados do limoneno contra a forma do ciclo encontrada no hospedeiro mamífero. Utilizamos amastigotas desta espécie de Leishmania pela facilidade de se obter um grande. 
L. (L.) major - promastigotas

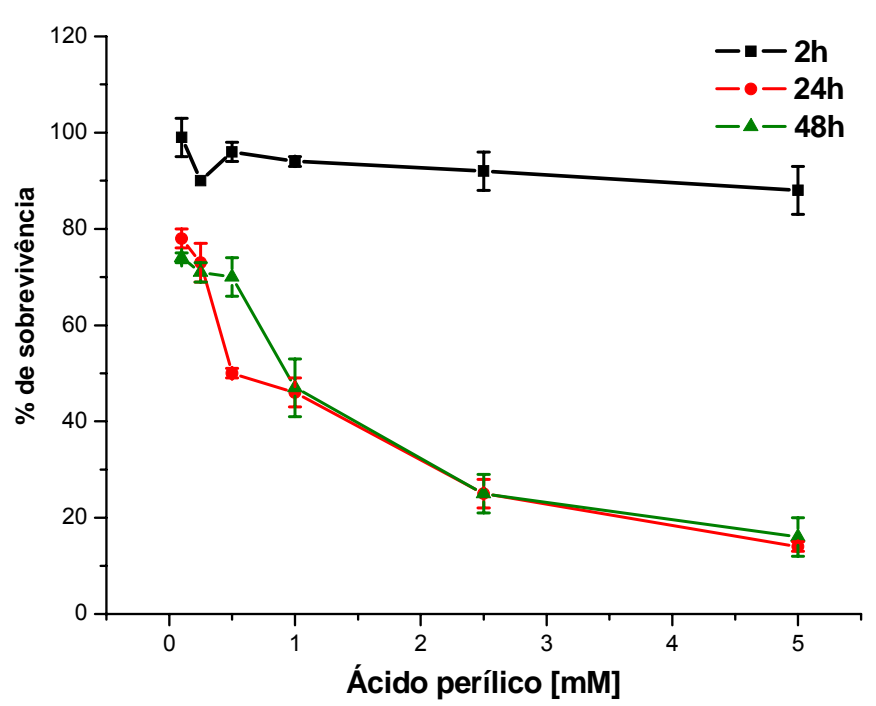

L. (L.) amazonensis - promastigotas

B

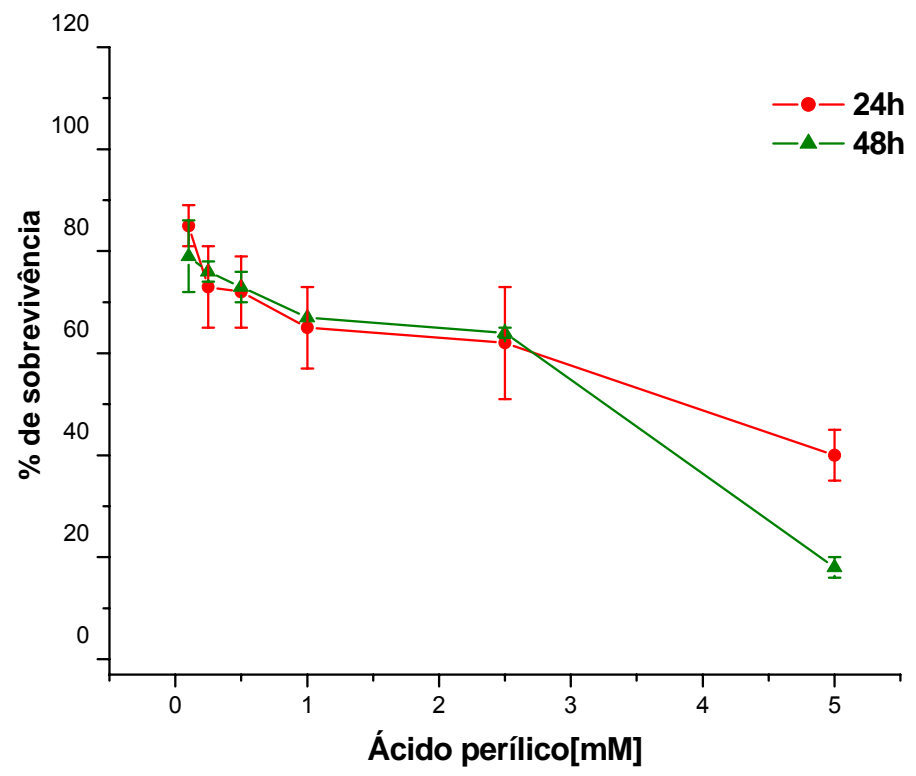

Figura 4 - Efeito do ácido perílico em culturas de promastigotas de $L$. (L.) major e $L$. (L.) amazonensis. Culturas de promastigotas foram incubadas com doses crescentes de aldeído perílico por 2, 24 e 48 horas. A viabilidade das células foi avaliada por MTT. (A) Promastigotas de L. (L.) major. (B) Promastigotas de L. (L.) amazonensis. 
número de parasitas a partir de lesão de camundongos após 12 semanas de infecção

Os amastigotas foram tratados com álcool, aldeído e ácido perílico em diferentes concentrações por 24 horas. O diluente da droga (1\% de etanol) utilizado em promastigotas mostrou-se tóxico para amastigotas, reduzindo o número de células sobreviventes em aproximadamente $45 \%$ do controle. Por isso se realizaram novos experimentos determinando-se que concentrações máximas de $0,4 \%$ de etanol não afetavam a sobrevivência das parasitas.

Observamos que ácido perílico não foi capaz de inibir a multiplicação de amastigotas (Fig. 5A). Álcool perílico apresentou atividade, calculando-se uma $\mathrm{IC}_{50}$ de 0,87 mM para tempos de incubação de 24 horas (Fig. 5A).

Aldeído perílico mostrou-se ativo contra amastigotas tratados por 24 horas, com $\mathrm{IC}_{50}$ de 0,12 mM. Sua atividade mostrou-se ainda mais intensa após períodos de 48 horas de tratamento, especialmente nas concentrações mais baixas da droga (Fig. 5B).

Observamos que mesmo as concentrações máximas utilizadas de cada droga não inibiram a multiplicação de amastigotas totalmente. A partir das porcentagens de sobrevivência obtidas, calculamos as $\mathrm{IC}_{50}$ das drogas para amastigotas (Tabela 3).

Mostrou-se que as $\mathrm{IC}_{50}$ calculadas para álcool e aldeído perílicos contra amastigotas foram próximas às descritas para promastigotas da mesma espécie, enquanto o ácido perílico foi ineficaz em promastigotas e amastigotas. 


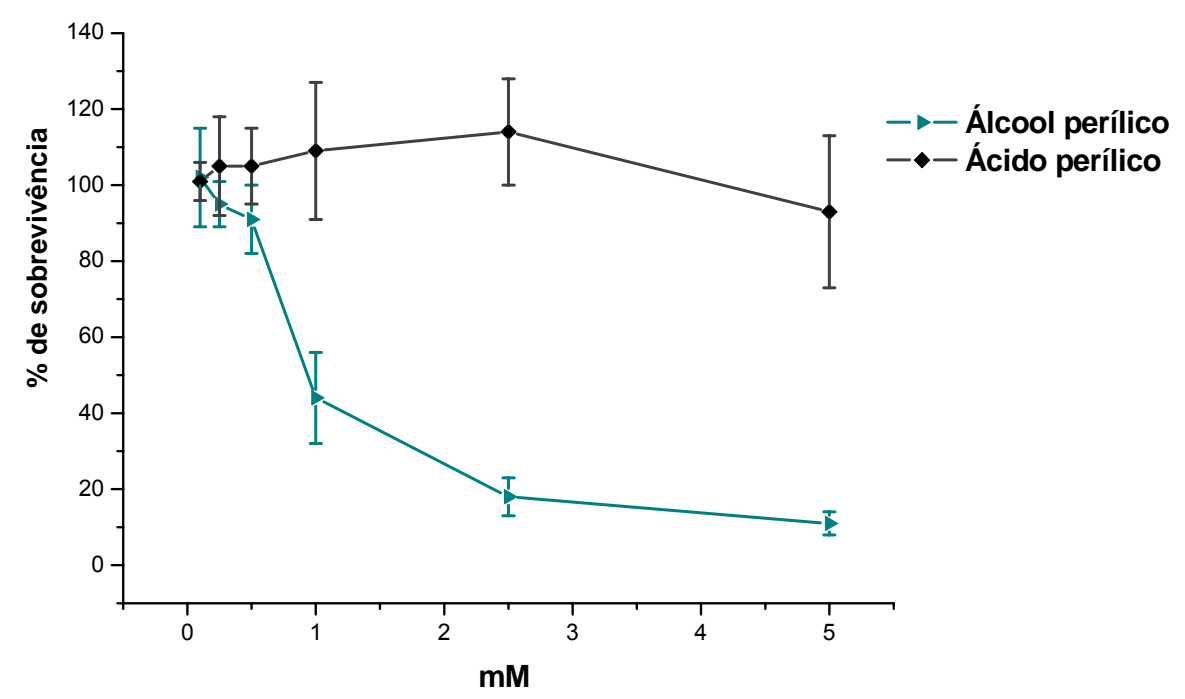

L.(L.) amazonensis - amastigota

B

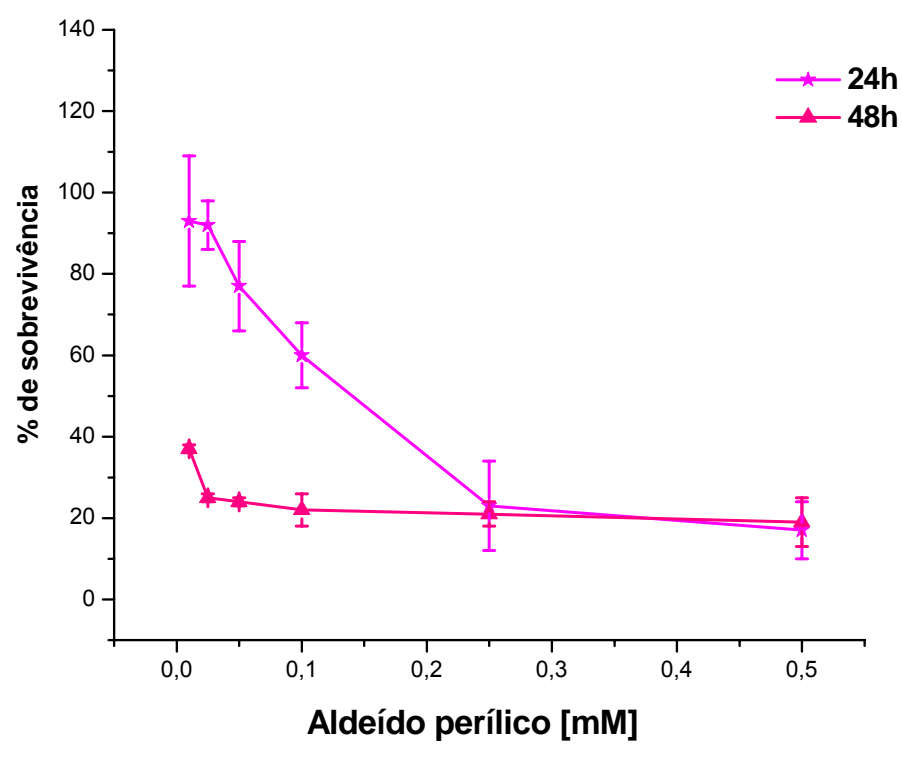

Figura 5 - Efeito dos metabólitos do limoneno em culturas de amastigotas de L. (L.) amazonensis. Culturas de amastigotas de $L$. (L.) amazonensis extraídos de lesão foram incubadas com doses crecentes das diferentes drogas. A viabilidade das células foi avaliada por MTT. (A) Efeito de álcool perílico e ácido perílico em 24 horas. (B) Aldeído perílico em 24 h e 48 horas. 
Tabela $3-\mathrm{IC}_{50}$ de álcool perílico, aldeído perílico e ácido perílico para amastigotas de L. (L.) amazonensis tratados por 24 horas.

\begin{tabular}{c|c|c|c}
$\mathbf{I C}_{\mathbf{5 0}}(\mathbf{m M})$ & Álcool perílico & Aldeído perílico & Ácido perílico \\
\hline $\mathbf{2 4 h}$ & $0,87 \pm 0,05$ & $0,12 \pm 0,01$ & NC
\end{tabular}

NC: Não foi possível calcular IC 50 após $24 \mathrm{~h}$ horas de incubação.

\subsubsection{Citotoxicidade dos derivados do limoneno e cálculo da concentração citotóxica em células de mamíferos}

A toxicidade de álcool, aldeído e ácido perílico foram avaliados em culturas in vitro de macrófagos $\mathrm{J774}_{\mathrm{A}} \mathrm{A}_{1}$, macrófagos de peritônio e fibroblastos humanos (HFF). Estas células foram incubadas por 24 horas na presença de diferentes concentrações das drogas, permitindo o cálculo das concentrações que inibiram a sobrevivência em $50 \%\left(\mathrm{CC}_{50}\right)$.As doses foram escolhidas levando-se em conta as utilizadas contra promastigotas de Leishmania.

Macrófagos J774. $\mathrm{A}_{1}$ mostraram-se extremamente sensíveis ao tratamento com os derivados de limoneno (Fig. 6), calculando-se $\mathbf{C C}_{50}$ de $0,45,0,05$ e 1,62 $\mathrm{mM}$, respectivamente, para álcool, aldeído e ácido perílicos. Os índices de

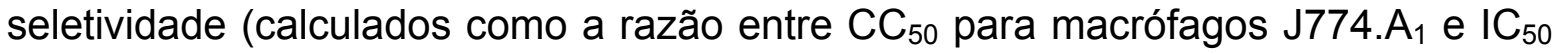
para amastigotas de L. (L.) amazonensis) para álcool e aldeído foram de 0,51 e 0,44, respectivamente. Os índices para álcool e aldeído perílico mostraram-se bastante baixos, indicando que essas drogas foram mais tóxicas para a célula do que para os próprios parasitas.

Os ensaios de citotoxicidade de álcool e aldeído perílicos foram também realizados com culturas de macrófagos de peritôneo e fibroblastos (Fig. 7), 

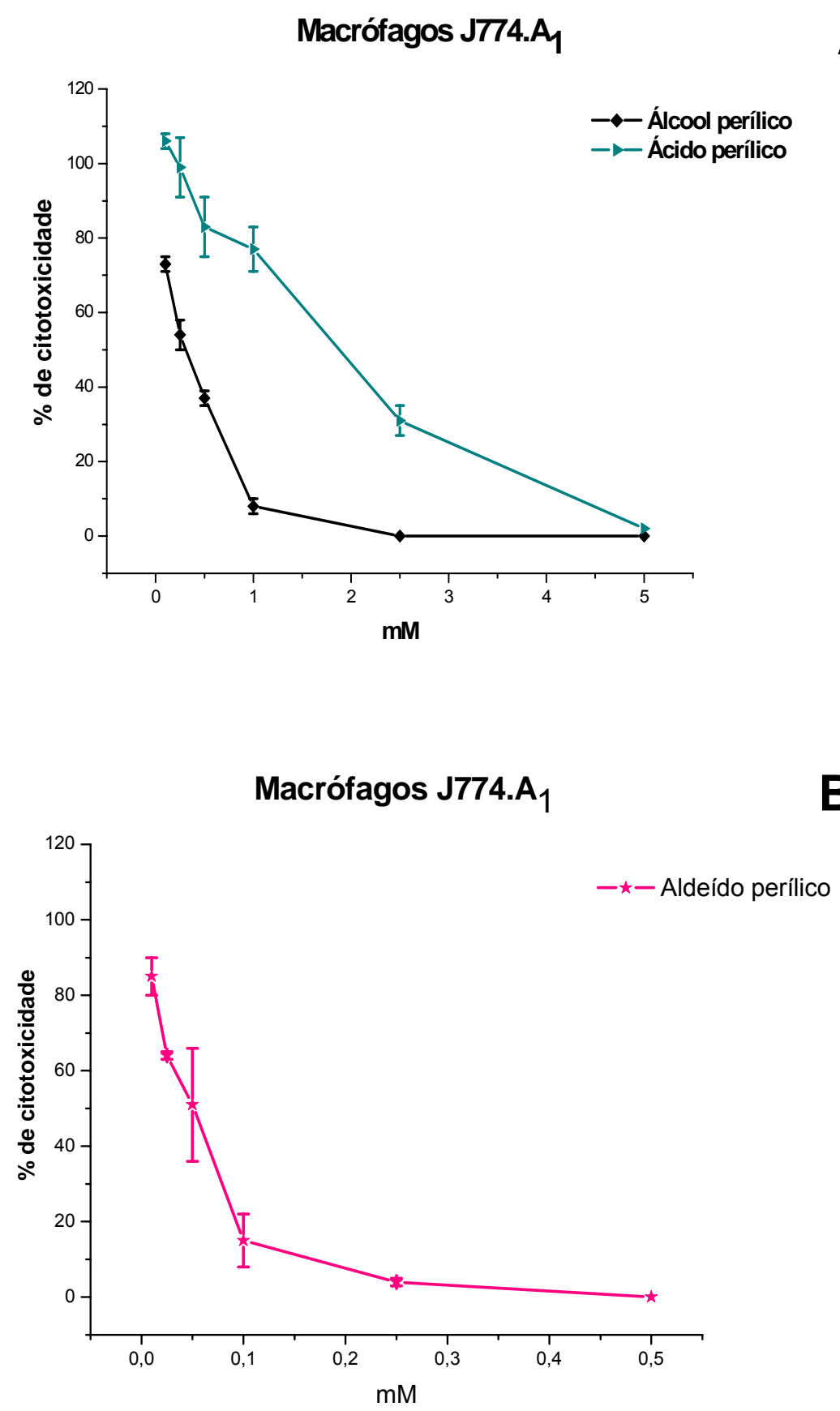

Figura 6 - Toxicidade do álcool perílico, aldeído perílico e ácido perílico para células de mamíferos. Culturas de macrófagos J774. $\mathrm{A}_{1}$ incubadas com álcool perílico e ácido perílico $(A)$ ou com aldeído $(B)$ nas concentrações indicadas, por $24 \mathrm{~h}$. A viabilidade das células foi analisada pelo teste de MTT e a porcentagem de sobrevivência calculada em relação às culturas não tratadas com a droga. 
o ácido perílico devido a sua baixa eficácia em ensaios in vitro contra promastigotas e amastigotas.

Macrófagos de peritônio tratados com álcool e aldeído perílico mostraram-se

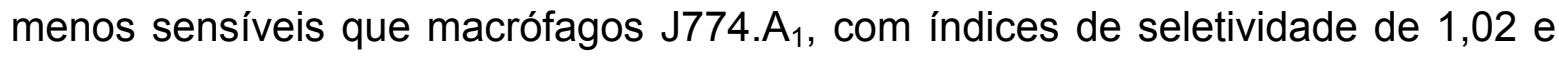
0,77. As mesmas drogas mostraram toxicidade menor no tratamento de fibroblastos com índices de seletividade de 3,28 e 2,85, respectivamente, para álcool e aldeído perílicos.

Os valores calculados para as $\mathrm{CC}_{50}$ das drogas em células de mamíferos são apresentados na tabela 4 .

Tabela $4-\mathrm{CC}_{50}$ de macrófagos e fibroblastos tratados com álcool perílico, aldeído perílico e ácido perílico.

\begin{tabular}{c|c|c|c}
$\mathbf{C C}_{50}(\mathrm{mM})$ & Álcool perílico & Aldeído perílico & Ácido perílico \\
\hline Macrófago J774.A & $0,45 \pm 0,06$ & $0,053 \pm 0,008$ & $1,62 \pm 0,16$ \\
\hline Macrófago de peritônio & $0,89 \pm 0,022$ & $0,093 \pm 0,013$ & $\mathrm{NR}$ \\
\hline Fibroblasto HFF & $2,86 \pm 0,5$ & $0,343 \pm 0,03$ & NR
\end{tabular}

NR: Experimento não realizado.

\subsubsection{Atividade de álcool perílico e aldeído perílico em amastigotas intracelulares.}

Apesar da alta toxicidade verificada em células de mamíferos, testamos também a atividade do tratamento e pré-tratamento com álcool perílico e aldeído perílico em culturas de macrófagos $\mathrm{J} 774 . \mathrm{A}_{1}$ e macrófagos de peritônio infectados com promastigotas de $L$. (L.) major. Para isso foram testadas diferentes 
Celúlas de mamiferos

A

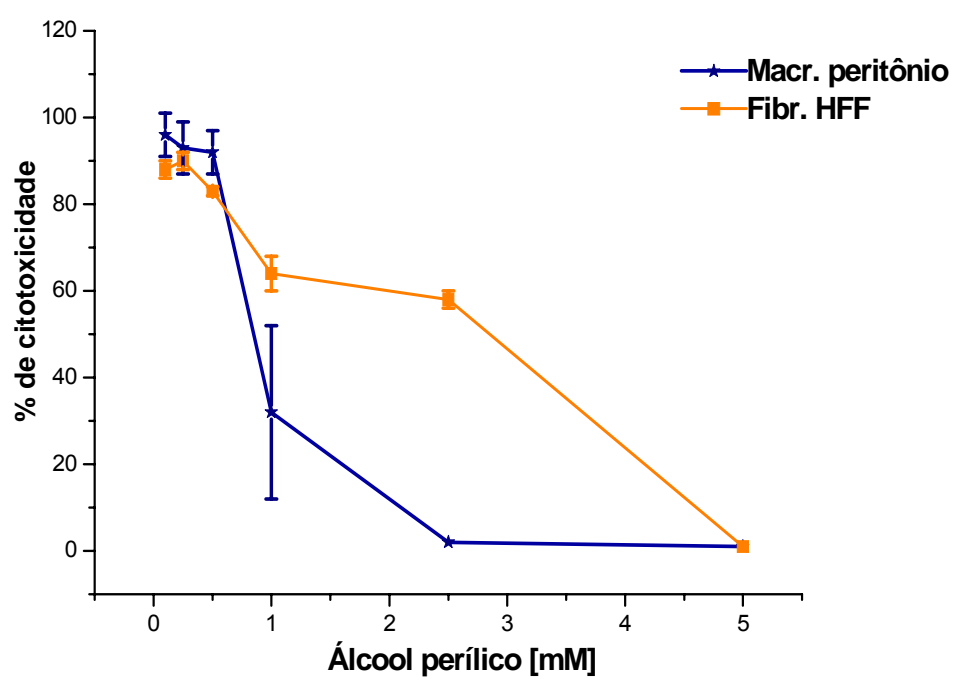

Celúlas de mamiferos

B

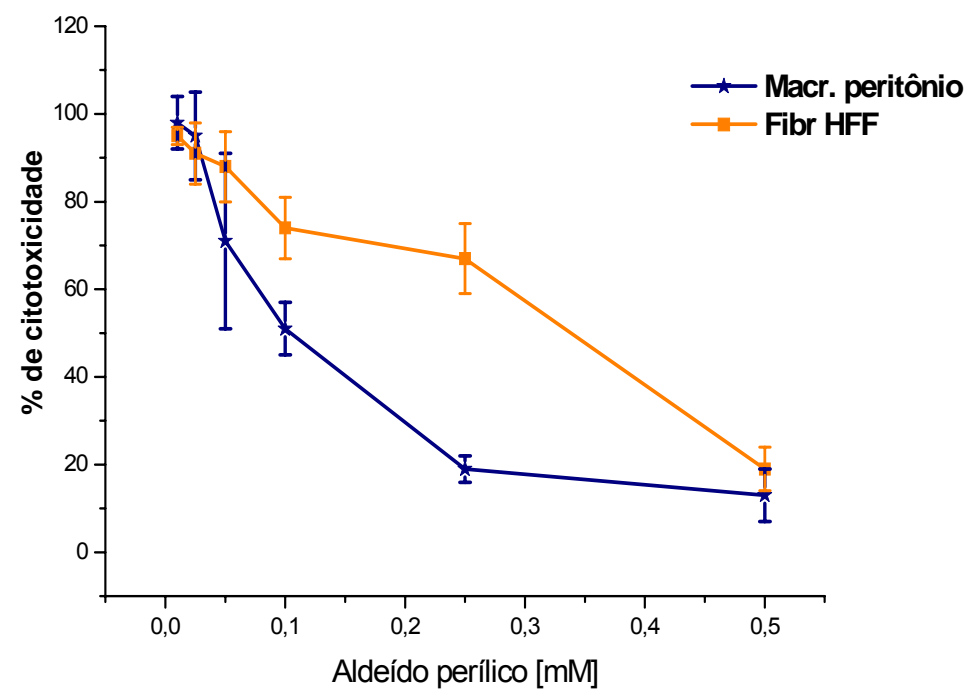

Figura 7 - Toxicidade do álcool perílico e aldeído perílico para células de mamíferos. Culturas de macrófago de peritônio e fibroblastos HFF incubadas com as drogas álcool perílico (A) ou aldeído perílico. A viabilidade das células foi avaliada como descrito na Fig. 6. 
concentrações de droga, levando em conta a $\mathrm{IC}_{50}$ calculada para promastigotas de L. (L.) major e a $\mathrm{CC}_{50}$ de macrófagos J774. $\mathrm{A}_{1}$ e macrófagos de peritônio.

Foi obtida uma porcentagem de infecção para os grupos não tratados de $34 \pm$ $2 \%$ com macrófagos $\mathrm{J} 774 . \mathrm{A}_{1}$ e de $42 \pm 1 \%$ em macrófagos de peritônio, indicando que os macrófagos de peritônio mostraram-se mais sensíveis à infecção por L. (L.) major que macrófagos $\mathrm{J} 774 . \mathrm{A}_{1}$. Essas porcentagens foram tomadas como controle e referência para calcular a redução no número de macrófagos infectados nos grupos tratados com as drogas (Fig. 8).

O tratamento com álcool perílico contra amastigotas intracelulares em macrófagos $J 774 . A_{1}$ resultou em redução de $43 \%$ na infecção na concentração máxima de 0,5 mM. Concentrações de 0,05 mM de aldeído perílico reduziram em $23 \%$ o número de macrófagos infectados (Tabela 5 e Figura 8).

Os testes descritos acima foram realizados com linhagens celulares contínuas. Tentando utilizar condições mais próximas das que ocorrem in vivo, a atividade dos derivados de limoneno também foi testada em infecções em macrófagos residentes de peritônio de camundongos BALB/c. Nesse caso, observamos redução de $31 \%$ no número de células infectadas após tratamento com álcool perílico e de $36 \%$ após tratamento com aldeído perílico nas concentrações máximas testadas (Tabela 6 e Figura 8).

Portanto, observamos que álcool e aldeído perílico foram capazes de reduzir o crescimento de amastigotas intracelulares nas doses utilizadas, que foram as máximas considerando-se a toxicidade in vitro. A atividade de álcool perílico e aldeído perílico também foram investigada avaliando-se o pré-tratamento de culturas de macrófagos de peritônio pelos tempos de 24 e 48 horas. 
Tabela 5 - Atividade de álcool perílico e aldeído perílico em amastigotas intracelulares.

\begin{tabular}{|l|c|c|c|c}
\hline & \multicolumn{4}{|c}{ Macrófagos J774.A (\% de infecção) } \\
\hline \multirow{2}{*}{ Álcool perílico } & Controle & $\mathbf{0 , 2 5} \mathrm{mM}$ & $\mathbf{0 , 4} \mathrm{mM}$ & $\mathbf{0 , 5} \mathrm{mM}$ \\
\cline { 2 - 5 } & $32 \pm 1$ & $29 \pm 2$ & $19 \pm 2$ & $18 \pm 1$ \\
\hline \multirow{2}{*}{ Aldeído perílico } & Controle & $\mathbf{0 , 0 2 5} \mathrm{mM}$ & $\mathbf{0 , 0 4} \mathrm{mM}$ & $\mathbf{0 , 0 5} \mathrm{mM}$ \\
\cline { 2 - 5 } & $35 \pm 1$ & $31 \pm 3$ & $29 \pm 2$ & $27 \pm 7$ \\
\hline
\end{tabular}

Tabela 6 - Atividade de álcool perílico e aldeído perílico em amastigotas intracelulares.

\begin{tabular}{|l|c|c|c|c}
\hline \multirow{2}{*}{ Álcool perílico } & \multicolumn{4}{|c}{ Macrófagos de peritônio (\% de infecção) } \\
\cline { 2 - 5 } & Controle & $\mathbf{0 , 2 5 m M}$ & $\mathbf{0 , 4} \mathbf{~ m M}$ & $\mathbf{0 , 5} \mathbf{~ m M}$ \\
\hline \multirow{2}{*}{ Aldeído perílico } & $42 \pm 1$ & $40 \pm 3$ & $37 \pm 1$ & $29 \pm 3$ \\
\cline { 2 - 5 } & $41 \pm 1$ & $29 \pm 1$ & $28 \pm 1$ & $\mathbf{0 , 0 5} \mathbf{m M}$ \\
\cline { 2 - 5 } & Controle & $\mathbf{0 , 0 2 5} \mathbf{~ m M}$ & $\mathbf{0 , 0 4} \mathbf{~ m M}$ & $26 \pm 3$ \\
\hline
\end{tabular}

Nesses experimentos, culturas de macrófagos não infectadas foram mantidas por 24 ou 48 horas na ausência (não pré-tratado) e na presença de concentrações crescentes de droga (pré-tratado), em experimentos independentes para cada tempo de incubação.

Ao final de 24 horas pós-infecção, a porcentagem de macrófagos de peritônio infectados no controle (não pré-tratados) foi de $57 \pm 3 \%$. Esse valor foi utilizado como referência para calcular a redução na porcentagem de infecção. 

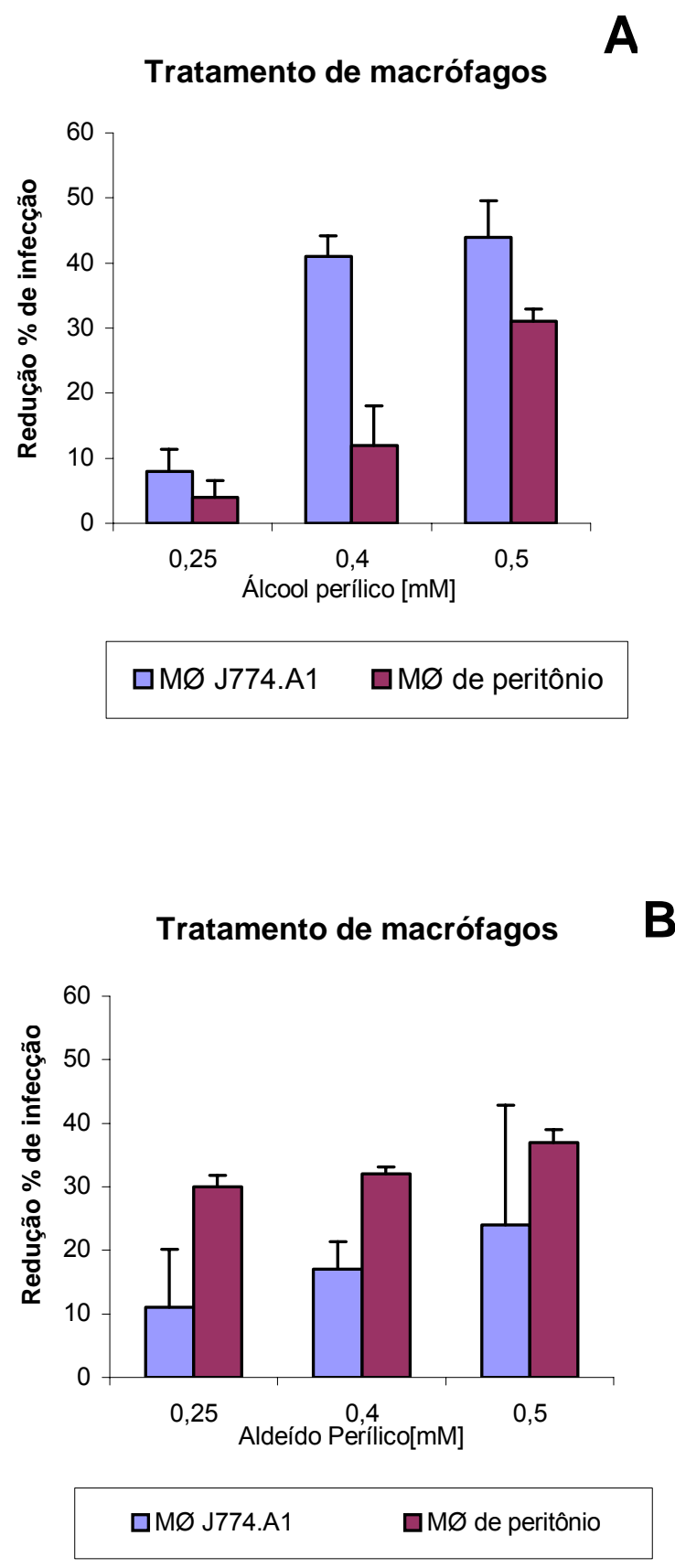

Figura 8. Efeito de álcool e aldeído perílico no crescimento de amastigotas intracelulares. Os gráficos mostram a redução da infecção em culturas de macrófagos $\mathrm{J} 774 . \mathrm{A}_{1}$ e de macrófagos de peritônio infectados com promastigotas de $L$. (L.) major e incubados por $24 \mathrm{~h}$ com diferentes concentrações de droga. A porcentagem de infecção em culturas não tratadas foi tomada como $100 \%$. (A) Álcool perílico; (B) Aldeído perílico. 
Após esse período, as células foram infectadas com L. (L.) major e submetidas a tratamento com as diferentes concentrações de droga por 24 horas.

Macrófagos de perítoneo foram pré-tratados com concentrações de 0,25;0,4 e 0,5 mM de álcool perílico. Células pré-tratadas com 0,5 mM de álcool perílico por 24 horas mostraram redução no número de células infectadas de $49 \%$, enquanto em culturas prétratadas por 48 horas a redução foi de 37\% (Fig. 9A).

Celulas pré-tratadas com $0,05 \mathrm{mM}$ de aldeído perílico mostraram redução na infecção de amastigotas intracelulares em $30 \%$ e $24 \%$ nos tempos de pretratamento de 24 e 48 horas, respectivamente (Fig. 9B).

Os porcentagens de infecção obtidas (Tabela 7) indicam que não houve diferença significativa entre os esquemas de pré-tratamento por $24 \mathrm{~h}$ ou 48 horas.

Tabela 7 - Atividade do pré-tratamento de álcool perílico e aldeído perílico em amastigotas intracelulares.

\begin{tabular}{l|c|c|c|c|c}
\hline \multirow{4}{*}{} & \multicolumn{5}{|c}{ Macrófagos de peritônio pré-tratados (\% de infecção) } \\
\hline \multirow{4}{*}{ Álcool perílico } & Tempoldroga & Controle & $\mathbf{0 , 2 5} \mathbf{~ m M}$ & $\mathbf{0 , 4} \mathbf{~ m M}$ & $\mathbf{0 , 5} \mathbf{~ m M}$ \\
\cline { 2 - 6 } & $\mathbf{2 4 h}$ & $57 \pm 3$ & $46 \pm 2$ & $40 \pm 2$ & $29 \pm 3$ \\
\cline { 2 - 6 } & $\mathbf{4 8 h}$ & $54 \pm 4$ & $43 \pm 5$ & $41 \pm 4$ & $34 \pm 2$ \\
\hline \multirow{3}{*}{ Aldeído perílico } & Tempoldroga & Controle & $\mathbf{0 , 0 2 5 m M}$ & $\mathbf{0 , 0 4 m M}$ & $\mathbf{0 , 0 5 m M}$ \\
\cline { 2 - 6 } & $\mathbf{2 4 h}$ & $57 \pm 3$ & $44 \pm 9$ & $43 \pm 2$ & $40 \pm 4$ \\
\cline { 2 - 6 } & $\mathbf{4 8 h}$ & $54 \pm 4$ & $42 \pm 4$ & $41 \pm 1$ & $41 \pm 2$ \\
\hline
\end{tabular}

A análise comparativa entre resultados obtidos com e sem pré-tratamento das células está apresentada na Figura 10. Observamos que houve um aumento da atividade de álcool perílico contra amastigotas intracelulares quando as células foram pré-tratadas com a droga, embora a diferença não tenha sido significativa 
Macrófagos pré - tratados

A

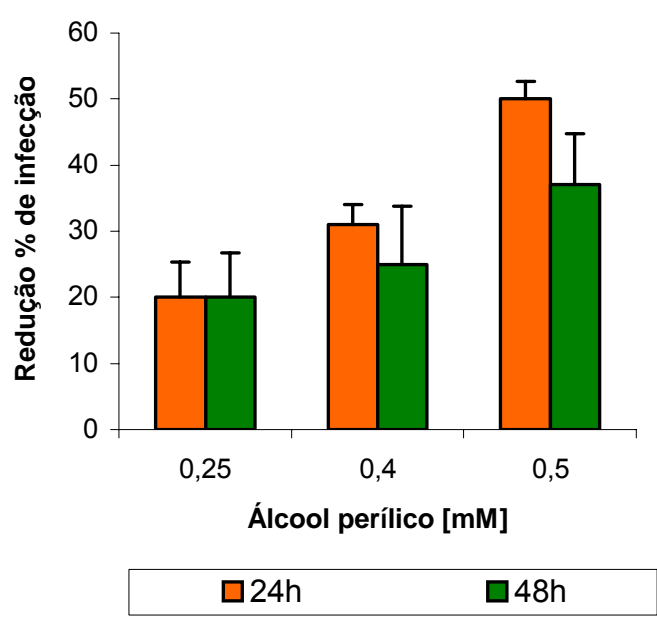

Macrófagos pré-tratados $B$

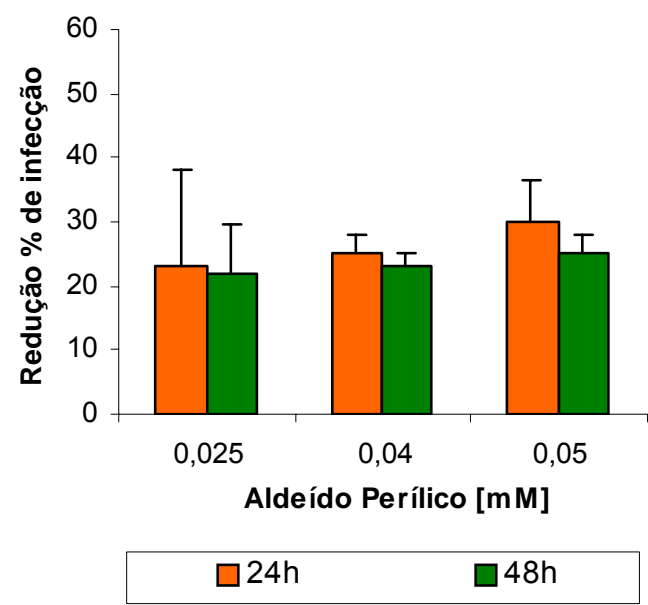

Figura 9 - Efeito de álcool e aldeído perílico no crescimento de amastigotas intracelulares em macrófagos pré-tratados. Culturas de macrófagos de peritônio foram tratadas por 24 ou $48 \mathrm{~h}$ com diferentes concentrações de álcool ou aldeído perílico. Essas células foram então infectadas com promastigotas de L. (L.) major e incubadas por 24 horas na presença das mesmas concentrações de droga. (A) Álcool perílico. (B) Aldeído perílico. A porcentagem de infecção em culturas não tratadas foi tomada como $100 \%$. 


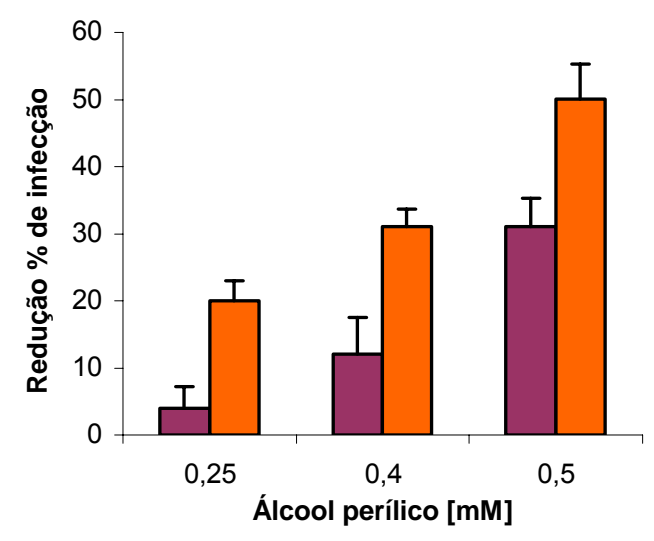

$$
\square \mathrm{M} \varnothing \text { tratado } \square \mathrm{M} \varnothing \text { pré - tratado }
$$

Comparação de macrófagos

B

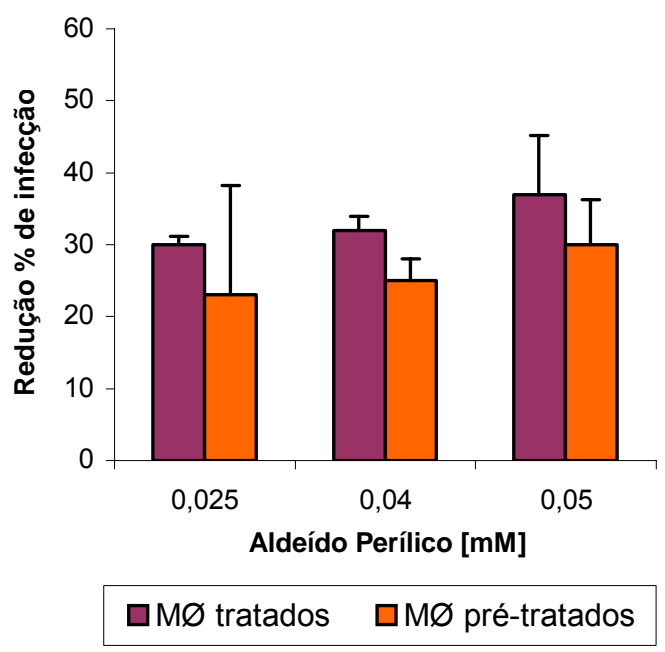

Figura 10 - Comparação do efeito de álcool e aldeído perílico no crescimento de amastigotas intracelulares em macrófagos na ausência e na presença de pré-tratamento. Redução na porcentagem de infecção de células tratadas apenas após infecção (MØ tratados), ou antes, e depois da infecção (MØ pré tratados) com álcool perílico (A) ou aldeído perílico (B). O tempo de tratamento após a infecção para ambos foi de 24 horas. 
$(P=0,06)$. mesmo não foi observado em relação a aldeído perílico que teve sua atividade mantida ou levemente reduzida em células pré-tratadas.

\subsubsection{Produção de óxido nítrico (NO) em macrófagos tratados e prétratados com álcool perílico e aldeído perílico.}

A maior atividade de álcool perílico contra amastigotas intracelulares em macrófagos pré-tratados sugeria que um dos possíveis mecanismos de ação essas drogas na redução da infecção de L. (L.) major em macrófagos in vitro seria a indução da síntese de NO pelas células macrofágicas. Portanto, foi avaliada a produção de $\mathrm{NO}$ em macrófagos $\mathrm{J} 774 . \mathrm{A}_{1}$ tratados com estas drogas e macrófagos de peritônio tratados e pré-tratados após infecção com L. (L.) major.

O experimento permitiu quantificar a produção de nitrito (produto da redução de NO) a partir de uma curva padrão de nitrito de sódio.

Após incubar os macrófagos tratados e pré-tratados com as diferentes concentrações de drogas, observamos que as concentrações de nitrito no sobrenadante das culturas não tratadas estavam abaixo do limite de detecção do protocolo (1,56 $\mu \mathrm{M}$ de nitrito). Não pudemos evidenciar qualquer aumento na acumulação de nitrito nas culturas, já que as dosagens permaneceram em níveis inferiores a 1,56 $\mu \mathrm{m}$. Nesses experimentos a produção de nitrito foi detectada em culturas tratadas com lipolissacarídeo (LPS) bacteriano, utilizadas como controle positivo. Assim, é provável que os derivados dos terpenos não induzam a produção de NO em macrófagos.

\subsubsection{Análise da isoprenilacão de proteínas em parasitas tratados com álcool perílico e aldeído perílico}


Considerando os dados da literatura que relacionam a atividade anti-tumoral dos derivados do limoneno principalmente à inibição da isoprenilacão, tentamos avaliar se os mecanismos de ação de álcool e aldeído perílico contra Leishmania também estariam relacionados a interferência na via dos isoprenóides nestes parasitas.

Para realizar marcações metabólicas com precursores de isoprenóides radioativamente marcados, precisávamos inicialmente estabelecer condições experimentais nas quais ocorresse atividade das drogas sem perda de viabilidade celular. Escolhemos avaliar a síntese protéica como critério para escolha de concentrações de droga.

Promastigotas de L. (L.) major e promastigotas e amastigotas de L. (L.) amazonensis foram tratados com diferentes concentrações de drogas e marcados metabolicamente com $\left[{ }^{35} \mathrm{~S}\right]$-metionina. Os extratos protéicos de parasitas controle e tratados foram então analisados por SDS-PAGE e observados através de autoradiografia.

Observamos que a incorporação em proteínas totais de promastigotas não foi alterada pelo tratamento com álcool perílico em concentrações de até $0,2 \mathrm{mM}$ ou com aldeído perílico até $0,03 \mathrm{mM}$. Estes resultados também foram verificados em amastigotas de L. (L.) amazonensis nas diferentes concentrações (Fig. 11).

Promastigotas de L. (L.) major foram então tratados com 0,02 mM de aldeído perílico e 0,2 mM álcool perílico e marcados com $\left[1(\mathrm{n})-{ }^{3} \mathrm{H}\right]$-farnesil pirofosfato e [1(n)- $\left.{ }^{3} \mathrm{H}\right]$-geranilgeranil pirofosfato (Fig. 12). 
Figura 11 - Marcação metabólica de promastigotas de L. (L.) amazonensis e L. (L.) major e amastigotas de $L$. (L.) amazonensis. Parasitas foram tratados com diferentes concentrações de álcool ( $A$ e $C$ ) e aldeído perílico ( $B$ e $D$ ). Após o tempo de incubação com as drogas os parasitas tratados e não tratados foram marcados com $\left[{ }^{35} \mathrm{~S}\right]$-metionina por 24 horas. Em cada canaleta foram aplicados extratos proteicos totais de $2 \times 10^{7}$ promastigotas de L. (L.) major (A e B) ou L. (L.) amazonensis (C) ou $4 \times 10^{7}$ amastigotas de $L$. (L.) amazonensis (D) Os extratos foram analizados por SDS-PAGE $(12 \%$ acrilamida) e expostos a autoradiografia por 7 dias. 
Figura 12 - Análise de isoprenilação de proteínas em promastigotas $L$. (L.) major.

Promastigotas tratados com $0,02 \mathrm{mM}$ de aldeído perílico (PCO), 0,5 $\mathrm{mM}$ de ácido perílico $(\mathrm{PCOOH})$ ou $0.2 \mathrm{mM}$ de álcool perílico $(\mathrm{POH})$ foram marcados em experimentos independentes com [3H]-GGPP (A) e [3H]-FFPP (B) por 24 horas. Em cada canaleta foi aplicado extrato proteico total de $5 \times 10^{7}$ promastigotas. Os extratos foram analisados por SDS-PAGE (12\% acrilamida), corados com azul de Coomassie (painéis à esquerda) e expostos a autoradiografia por 60 dias (painéis à direita). 
Em parasitas marcados com $\left[1(n)-{ }^{3} \mathrm{H}\right]$-farnesil pirofosfato não observamos incorporação em bandas protéicas, sugerindo que esse precursor poderia não estar sendo incorporado ou que as concentrações de precursor utilizadas seriam insuficientes para evidenciar bandas na auto-radiografia. A marcação com o segundo precursor $\left(\left[1(\mathrm{n}){ }^{3}{ }^{3} \mathrm{H}\right]\right.$-geranilgeranil pirofosfato) resultou na detecção de apenas uma mancha na autoradiografia, na base do gel abaixo da banda com massa molecular de aproximadamente $12 \mathrm{kDa}$. Possivelmente trata-se do radioativo não incorporado. Nos dois casos, a coloração do gel com azul de Coomassie permitiu confirmar que 0 tratamento dos parasitas com essas concentrações de droga não alterou o padrão global de proteínas (Fig. 12).

\subsection{Determinação da atividade dos derivados do limoneno em experimentos in vivo}

Uma vez determinada a atividade dos metabólitos do limoneno in vitro, foram realizados testes para verificar o efeito destes derivados no tratamento de leishmaniose experimental em camundongos BALB/c.

Foram feitos experimentos in vivo com as duas espécies de Leishmania, $L$. (L.) amazonensis e L. (L.) major. A primeira é altamente agressiva na evolução da doença, portanto uma boa resposta das drogas nesta espécie nos mostraria a eficácia do tratamento. A segunda tem uma evolução mais lenta e poderia favorecer uma resposta mais efetiva das drogas aplicadas.

As vias de aplicação utilizadas nesses experimentos foram as vias tópica, intra-retal e intra-peritonial. $\mathrm{O}$ tratamento por via tópica foi feito utilizando soluções da droga em etanol em volume total de $10 \mu \mathrm{L}$ ou preparações em creme Lanette. No caso da via intra-retal as drogas foram diluídas em $5 \%$ de etanol em PBS 
aplicando-se um volume final de $20 \mu \mathrm{L}$ e para a via intraperitoneal foi utilizada uma emulsão da droga com PBS em volumes máximos de $50 \mu \mathrm{L}$.

Os camundongos BALB/c escolhidos foram de uma faixa etária de 6-8 semanas com peso médio de 20-22 gramas, os quais foram inoculados com as duas espécies de Leishmania na forma amastigota: $1 \times 10^{6}$ para L. (L.) amazonensis e $2 \times 10^{6}$ para L. (L.) major. O sítio de inoculação foi a base da cauda para evitar a remoção do creme no caso do tratamento tópico e para facilitar a medida da lesão. O tratamento começou 2 semanas após a inoculação dos parasitas para o grupo inoculado com L. (L.) amazonensis e após 3 semanas para o grupo inoculado com L. (L.) major.

Foram avaliadas a tolerância e atividade de álcool perílico e aldeído perílico pelas diferentes vias. As doses utilizadas de álcool perílico foram baseadas em dados publicados (HAAG; GOULD, 1994; RIPPLE et al., 2000). Como estudos semelhantes com aldeído perílico não estão disponíveis, seguimos as mesmas referências de álcool perílico.

\subsubsection{Toxicidade do álcool perílico e aldeído perílico em camundongos}

\section{BALB/C}

Grupos de 5 camundongos BALB/c foram utilizados inicialmente para avaliar a tolerância dos animais à aplicação das drogas.

O tratamento para verificar toxicidade para álcool e aldeído perílico por via tópica foi realizado com doses de 0,25 ou $0,5 \mathrm{~g} / \mathrm{kg} / \mathrm{dia}$ da droga por 2 semanas ininterruptas. Trabalhos de (HUDES et al., 2000) utilizaram doses de álcool perílico de $2100 \mathrm{mg} / \mathrm{m}^{2}$ a $2800 \mathrm{mg} / \mathrm{m}^{2}$ em humanos por via oral, com efeitos colaterais moderados. Esses valores foram utilizados como referência no tratamento por via 
intra-retal, adotando-se doses máximas de $1 \mathrm{~g} / \mathrm{kg} / \mathrm{dia}$ por 2 semanas com uma interrupção de 24 horas no $7^{\circ}$ dia. No transcurso da aplicação foram avaliados os seguintes parâmetros: peso, aparência do local da aplicação e sinais sistêmicos de toxicidade como atividade, agressividade e aspecto da pelagem.

Durante as 2 semanas de tratamento e por 2 semanas após sua interrupção não foram notadas diferenças significativas no peso dos animais que receberam álcool ou aldeído perílico por vias tópica ou intra-retal (Fig. 13).

Para o grupo de camundongos tratados por via tópica observamos aparência saudável da área tratada, sem sinais de irritação local, além de comportamento normal dos camundongos dentro da gaiola. Os animais que receberam as drogas por via intra-retal se mostraram inquietos e agitados nos últimos dias de aplicação, possivelmente devido ao trauma da manipulação. Essa irritabilidade não foi notada nas 2 semanas de observação após a interrupção do tratamento. Em todos os grupos a pelagem esteve em condições normais.

\subsection{2 Álcool perílico no tratamento de leishmaniose experimental}

Uma vez verificada a falta de toxidade aparente in vivo por ambas as vias de aplicação, passamos a avaliar a atividade destes metabólitos do limoneno em camundongos BALB/c infectados por L. (L.) amazonensis e L. (L.) major.

Duas semanas após a infecção de camundongos BALB/c com $L$. (L.) amazonensis foi iniciado o tratamento por via tópica com creme lanette contendo $10 \%$ de álcool perílico. O creme foi aplicado sobre a lesão uma vez ao dia por 3 semanas. Observamos que os camundongos infectados apresentaram edema na área de inoculação mostrando a evolução da doença. A comparação entre os grupos tratados e o grupo controle sem tratamento mostrou que não houve 


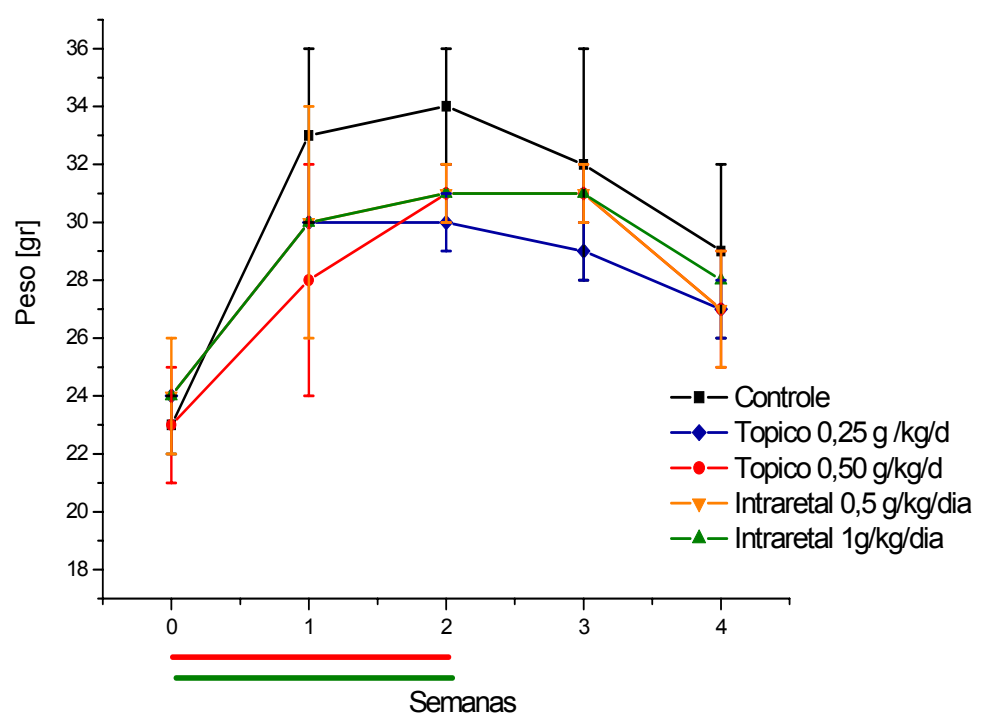

Toxicidade de aldeído perílico em BALB/c

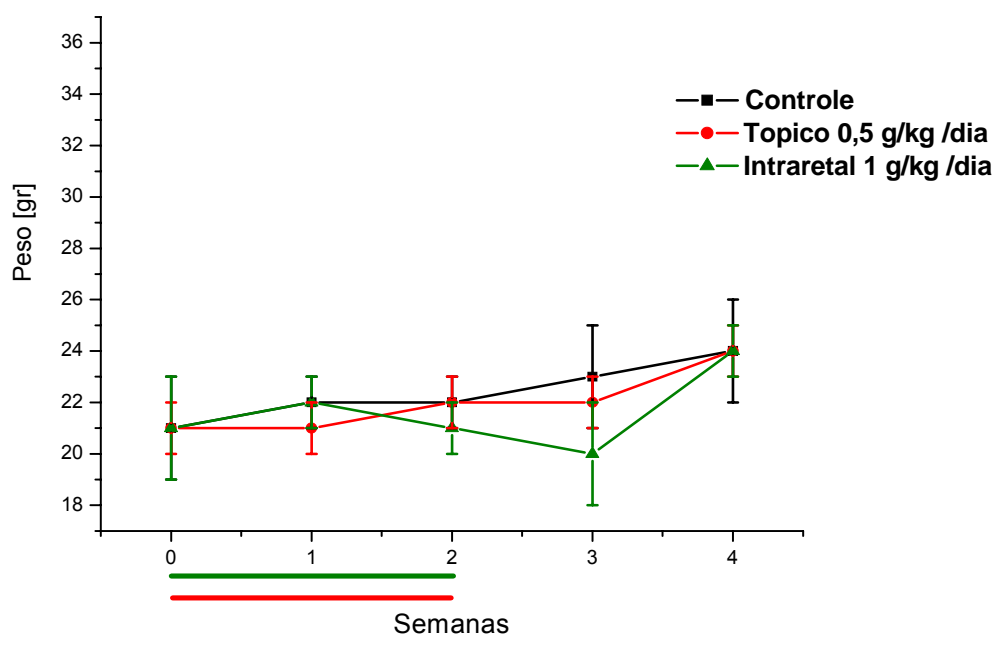

Figura 13 - Toxicidade dos derivados do limoneno. Evolução do peso de camundongos $\mathrm{BALB} / \mathrm{c}$ tratados com álcool ou aldeído perílico por via tópica (solução) e intra-retal (solução). O tempo de tratamento foi de 2 semanas e 2 semanas de acompanhamento para ambas vias. (A) Álcool perílico tópico em doses de 0,25 e 0,5 g/ $\mathrm{kg} / \mathrm{dia}$ e via intra-retal 0,5 e 1 g/kg/dia. (B) Aldeído perílico tópico 0,5 g/kg/dia e via intra-retal $1 \mathrm{~g} / \mathrm{kg} / \mathrm{dia}$. 
diferença na evolução das lesões durante 7 semanas após a interrupção do tratamento (Fig. 14A).

O tratamento de animais infectados com L. (L.) major por via tópica foi feito utilizando-se o mesmo esquema descrito acima. Nesse caso também não observamos diferenças no tamanho da lesão quando comparados os grupos tratados com o grupo controle (Fig. 14B).

O tratamento por via intra-retal foi realizado injetando-se doses de $1 \mathrm{~g} / \mathrm{kg} / \mathrm{dia}$, aplicados como solução contendo $5 \%$ de etanol como solvente em volume final de 20-30 $\mu \mathrm{L}$. Os animais foram tratados com uma aplicação ao dia por 2 semanas.

Não foram observadas diferenças entre os grupo tratados e o grupo controle durante o período de aplicação da droga, característica que se manteve 7 semanas após o tratamento tanto para os camundongos infectados com L. (L.) amazonensis (Fig. 14A) quanto para L. (L.) major ( $P>0,1)$ (Fig. 14B).

A aplicação de álcool perílico por via intraperitoneal foi avaliada em camundongos BALB/c infectados com L. (L.) major. Esta via mostrou-se efetiva em experimentos no laboratório feitos com outro terpeno por isso a escolha desta. Os experimentos foram feitos em grupos de 6 camundongos por gaiola tratados com concentrações de $0,5 \mathrm{~g} / \mathrm{kg} / \mathrm{dia}$ por 3 semanas. Novamente não foram observadas diferenças na evolução das lesões quando comparados com o grupo controle $(P>0,5)($ Fig. 15).

Os resultados apresentados nestes experimentos no tratamento in vivo com álcool perílico de camundongos infectados por L. (L.) amazonensis e L. (L.) major por via tópica, intra-retal e intraperitoneal mostraram que este monoterpeno não tem atividade no tratamento da doença. 
BALB/c infectados com L (L) amazonensis tratados comálcool perílico

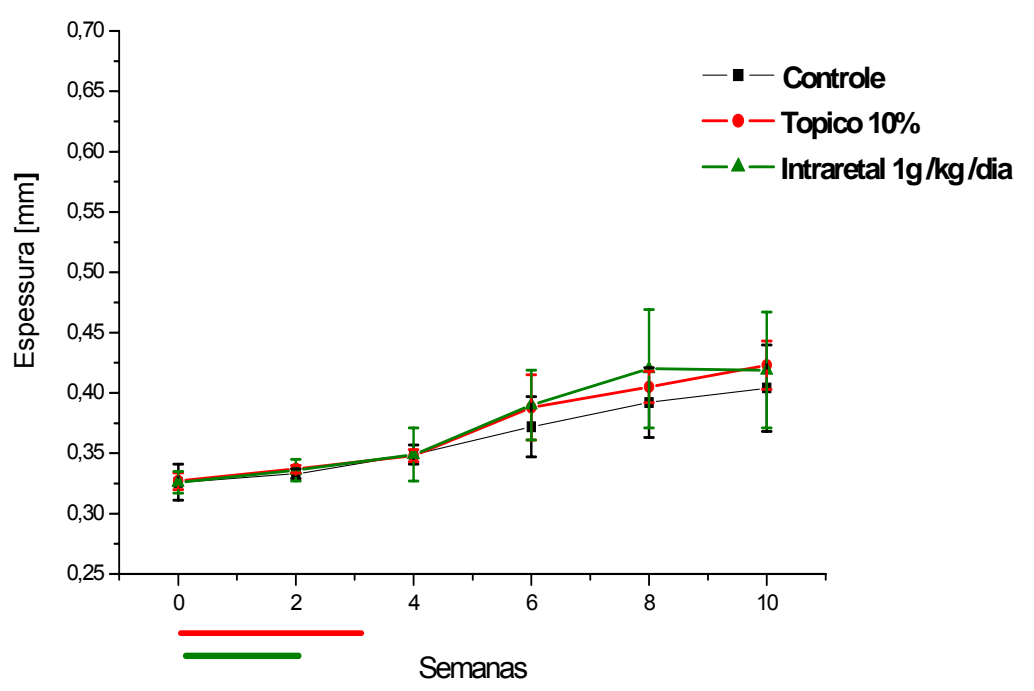

BALB/c infectados com L. (L.) major tratados com álcool perílico

B

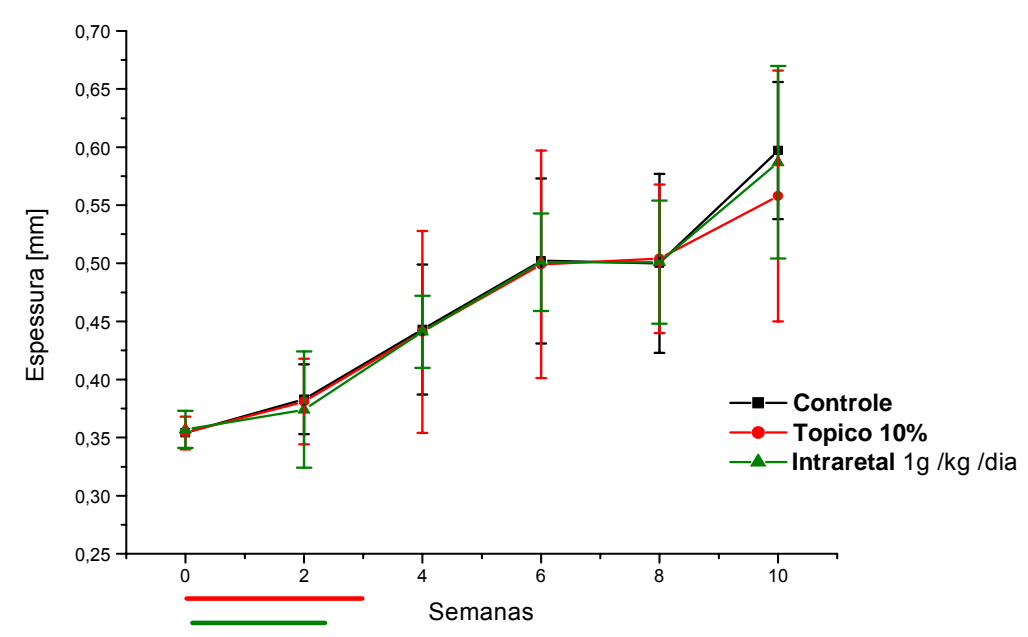

Figura 14. Atividade de álcool perílico no tratamento de leishmaniose. Evolução do tamanho da lesão de camundongos BALB/c infectados com L. (L.) amazonensis (A) ou L. (L.) major (B) e tratados por via tópica ou intra-retal. Para o tratamento por via tópica foi utilizado creme com $10 \%$ da droga aplicado sobre a lesão 1 vez ao dia por 3 semanas. Para o tratamento por via intra-retal a dose utilizada foi $1 \mathrm{~g} / \mathrm{kg} / \mathrm{dia}$ por 2 semanas. $O$ tamanho da lesão foi avaliado através do diâmetro médio da cauda. As barras indicam o período de tratamento. 


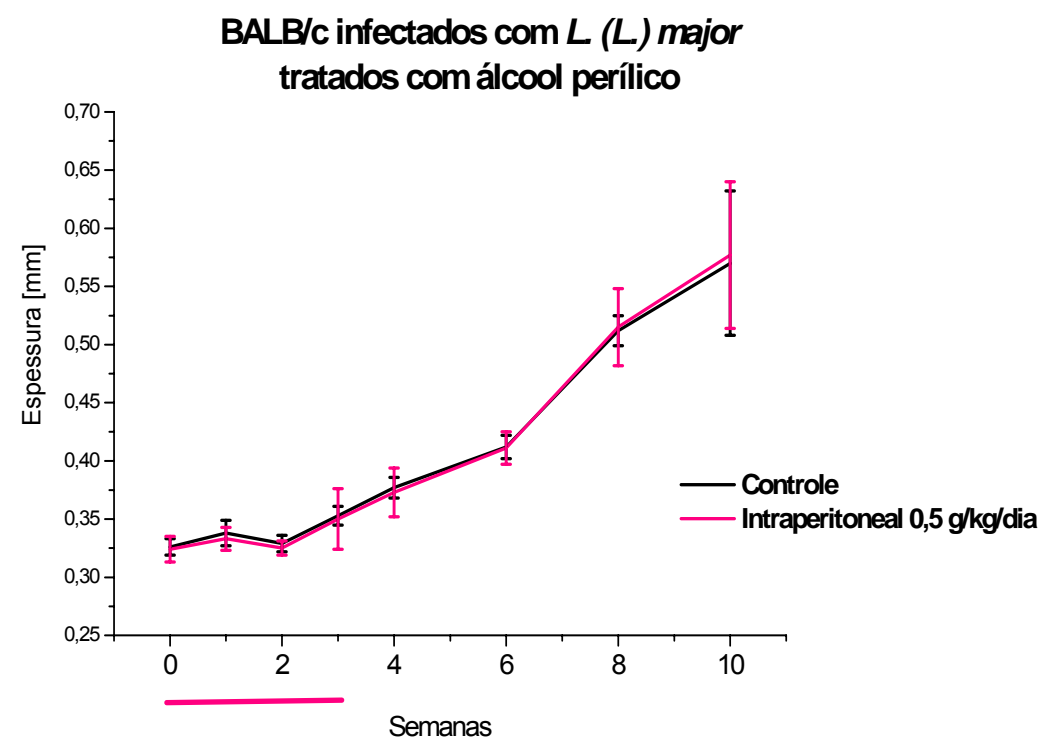

Figura 15 - Atividade de álcool perílico no tratamento de leishmaniose. Experimentos in vivo feitos em camundongos BALB/c infectados com L. (L.) major e tratados com álcool perílico por via intraperitoneal em doses de $0,5 \mathrm{~g} / \mathrm{kg} / \mathrm{dia}$ por 3 semanas e acompanhamento de 7 semanas. A avaliação das lesões foi feita da mesma forma que na Fig. 14.

\subsubsection{Aldeído perílico no tratamento de leishmaniose experimental}

A atividade de aldeído perílico no tratamento de camundongos BALB/c infectados com L. (L.) major e L. (L.) amazonensis foi testada utilizando as mesmas vias de aplicação descritas para álcool perílico.

Para o tratamento tópico, os camundongos infectados foram separados em grupos de 6 camundongos por gaiola com um grupo controle e tratados com creme lanette contendo $10 \%$ de aldeído perílico. Foi realizada uma aplicação por dia sobre a área da lesão durante 3 semanas.

Os resultados mostraram que não houve diferença entre a evolução das lesões de camundongos tratados com aldeído perílico e os do grupo controle 
durante o período de aplicação da droga, característica que se manteve após o tratamento no acompanhamento por 4 semanas (resultados não apresentados).

Considerando-se a possibilidade de metabolização rápida da droga a outros derivados, foi também testado o tratamento com creme contendo aldeído perílico na mesma concentração, mas com 3 aplicações ao dia durante 3 semanas, em camundongos BALB/c infectados com L. (L.) amazonensis e L. (L.) major. Apesar de não termos observados qualquer sinal de toxicidade, a evolução das lesões foi similar em camundongos tratados por via tópica e controles não tratados $(P>0,13)$ (Fig. 16).

O tratamento por via intra-retal com aldeído perílico foi realizado com doses de 1g/kg/dia (uma aplicação diária) e 2g/kg/dia (divididos em duas doses) por 2 semanas. Camundongos infectados com L. (L.) amazonensis ou L. (L.) major e tratados com doses de $1 \mathrm{~g} / \mathrm{kg} / \mathrm{dia}$ não apresentaram redução no tamanho das lesões durante ou após o tratamento (resultados não mostrados).

Em camundongos BALB/c infectados por L. (L.) amazonensis e tratados com doses de $2 \mathrm{~g} / \mathrm{kg} /$ dia observamos evolução mais lenta das lesões a partir da quinta semana, comportamento que se manteve até a sétima semana, mas sim diferenças significativas ( $P>0,09)$ (Fig. 16A). Já na infecção por L. (L.) major, não foram observadas diferenças, mesmo com doses mais elevadas $(P>0,1)$ (Fig. 16B).

Aldeído perílico aplicado por via intra-retal, mesmo em diferentes freqüências de aplicação, não se mostrou tóxico em camundongos infectados tanto por $L$. (L.) amazonensis quanto L. (L.) major.

O tratamento intraperitoneal foi avaliado em camundongos BALB/c infectados com L. (L.) major. Os experimentos foram feitos com doses de 0,5 g/kg/dia por 3 semanas e o acompanhamento até a sétima semana após a interrupção do 
BALB/c infectados com L. (L.) amazonensis tratados com aldeído perílico

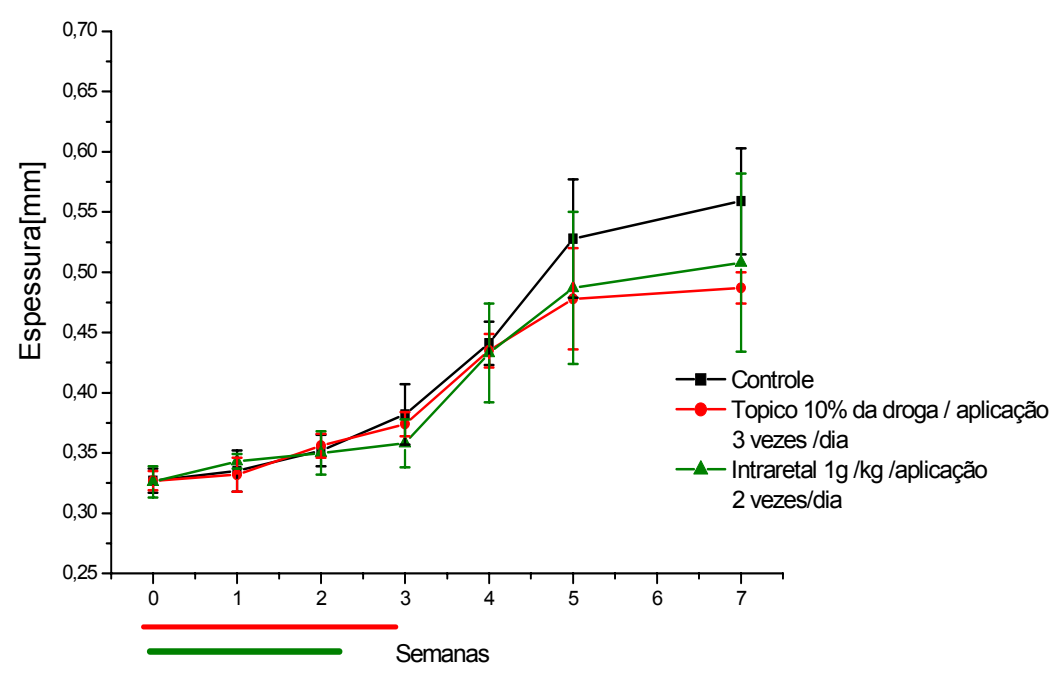

BALB/c infectados com L. (L.) major tratados com aldeído perílico

B

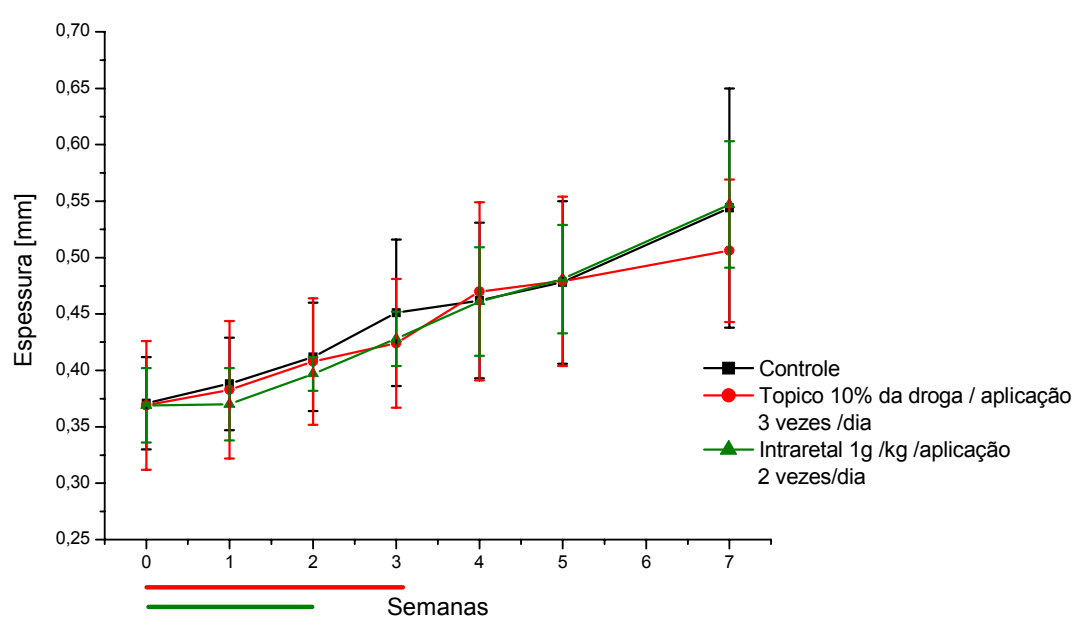

Figura 16 - Atividade de aldeído perílico no tratamento de leishmaniose. Experimentos in vivo feitos em camundongos BALB/c infectados e tratados por via tópica (creme) e via intra-retal (solução). O esquema de tratamento por via tópica utilizou preparação de creme Lanette com $10 \%$ da droga, aplicado 3 vezes ao dia por 3 semanas. As doses por via intra-retal foram de $1 \mathrm{~g} / \mathrm{kg} /$ aplicação 2 vezes ao dia por 2 semanas. Acompanhamento de 4 e 5 semanas respectivamente. A avaliação das lesões foi feita da mesma forma que na Fig. 14. (A) Camundongos infectados com L. (L.) amazonensis. (B) Camundongos infectados com L. (L.) major. 
tratamento não revelou diferenças entre os grupos controle e tratado $(P=0,76)$ (Fig. 17).

\subsubsection{Determinação da atividade da associação de álcool perílico e aldeído perílico no tratamento de leishmaniose experimental}

A atividade da associação destes monoterpenos foi testada em camundongos BALB/c infectados com L. (L.) amazonensis. Utilizamos a via de aplicação tópica, com creme lanette contendo 10\%de álcool perílico e 10\% de aldeído perílico. Foram realizadas aplicações 2 vezes ao dia por 3 semanas. Não observamos diferenças entre os grupos tratado e controle, de forma semelhante ao que havia sido observado com cada uma das drogas individualmente $(P=0,13)$ (Fig. 18).

A associação também foi testada por via intraperitoneal em camundongos infectados com L. (L.) amazonensis. Foram utilizadas doses de 0,25 mg/kg/dia de cada terpeno, preparadas em conjunto em emulsão em PBS. Nesse caso, os camundongos tratados evoluíram com redução significativa no tamanho da lesão, notada a partir da segunda semana, ou seja, ao final do tratamento e que persistiu até a sétima semana de acompanhamento $(P<0,005)$ (Fig. 19). 


\section{BALB/c infectado com L. (L.) major}

Tratados com aldeído perílico

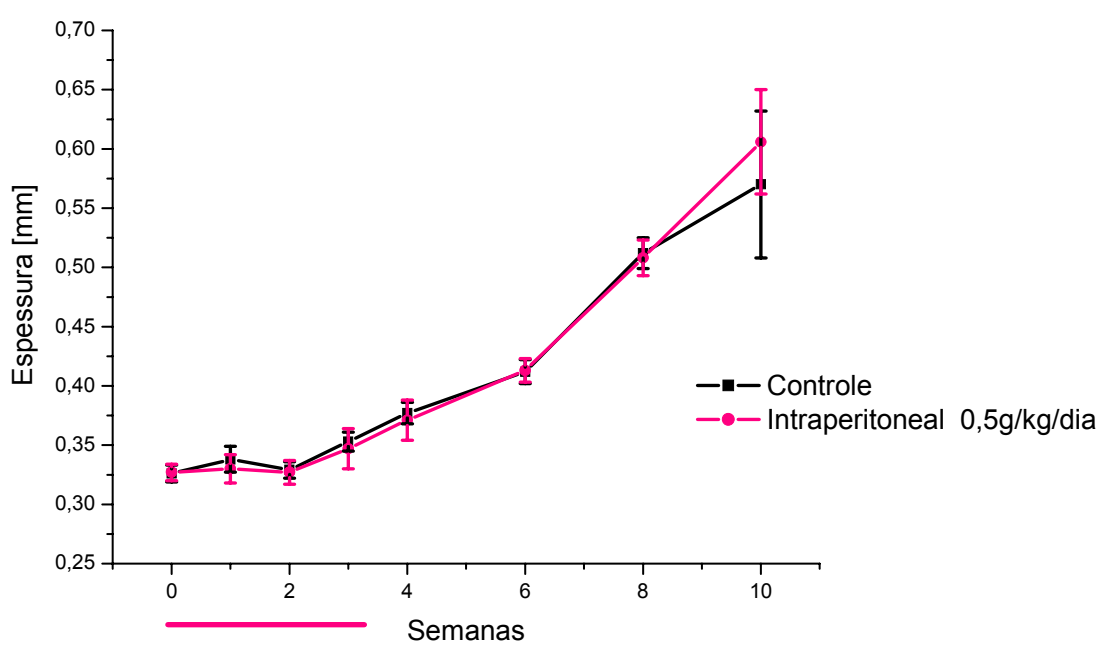

Figura 17 - Atividade de aldeído perílico. Experimentos in vivo feitos em camundongos BALB/c infetados com L. (L.) major e tratados com álcool perílico por via intraperitoneal em doses de $0,5 \mathrm{~g} / \mathrm{kg} /$ dia por 3 semanas e acompanhamento de 4 semanas. A avaliação das lesões foi feita da mesma forma que na Fig. 14.

BALB/c infectados com L. (L.) amazonensis tratados com a mistura de álcool e aldeído perílico

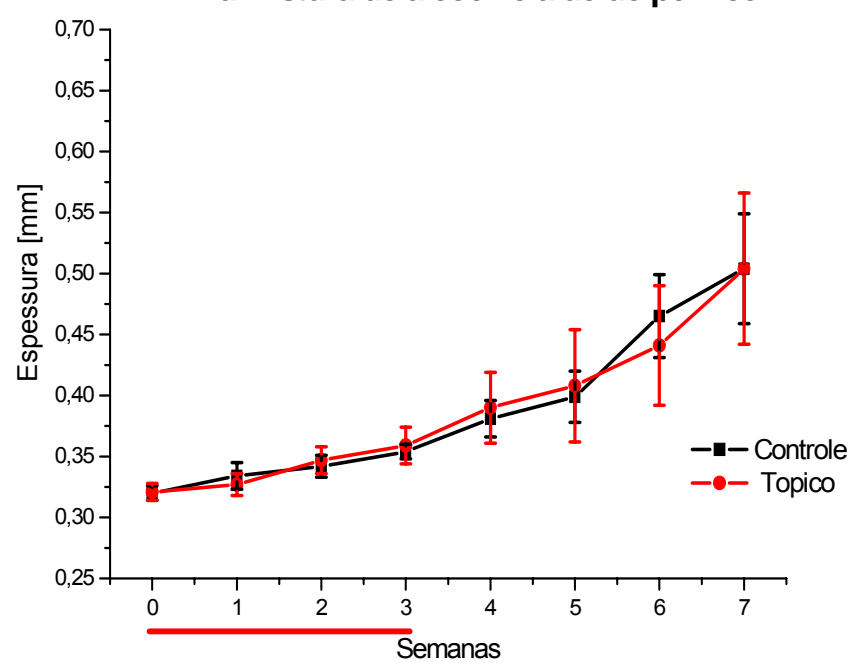

Figura 18 - Atividade da associação de álcool perílico e aldeído perílico por via tópica (creme). Camundongos BALB/c infectados com L. (L.) amazonensis, tratados por via tópica com creme contendo $10 \%$ de álcool e aldeído perílico. O creme foi aplicado 2 vezes ao dia por 3 semanas. A barra indica o período de tratamento. 


\section{BALB/c infectados com $L(L)$ amazonensis tratados com}

a mixtura de álcool e aldeído perílico

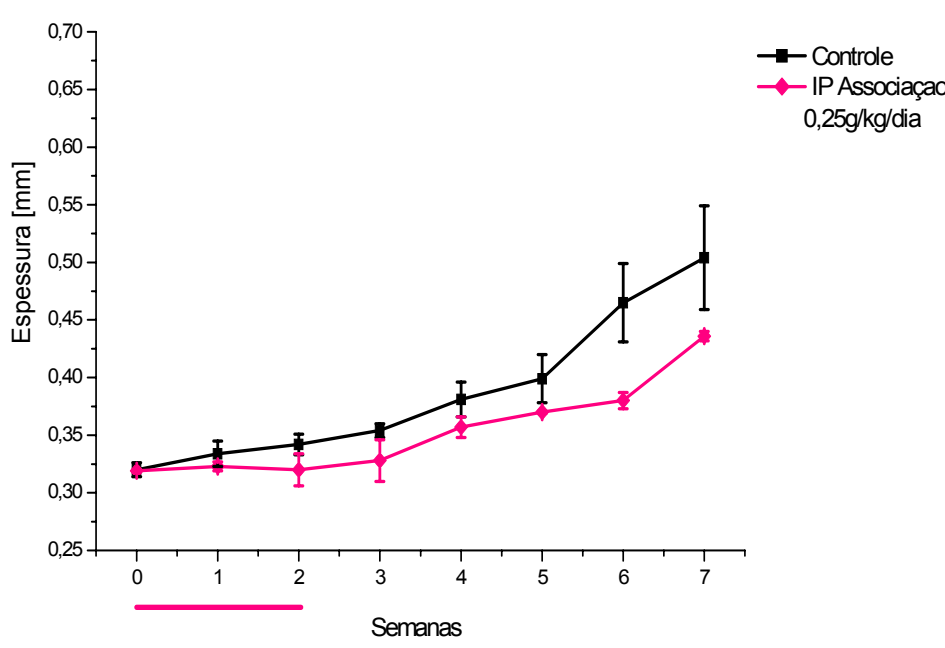

Figura 19 - Atividade da associação de álcool perílico e aldeído perílico por via intraperitoneal.Camundongos BALB/c infectados com L. (L.) amazonensis tratados por via intraperitoneal com $0,25 \mathrm{~g} / \mathrm{kg} / \mathrm{dia}$ de álcool e aldeído perílicos. O tempo de tratamento foi de 2 semanas e o acompanhamento de 6 semanas. A avaliação das lesões foi feita da mesma forma que na Fig. 14 


\section{DISCUSSÃO}

Não resta dúvida de que as ferramentas disponíveis para o tratamento medicamentoso de leishmaniose, em suas diversas apresentações clínicas, são inadequadas. Seja por sua toxicidade, por sua via de administração ou pela resistência adquirida pelo parasita, as drogas usadas hoje têm resultados bastante insatisfatórios. Portanto, a busca de novas alternativas para o tratamento dessa parasitose é mais do que justificado.

Os terpenos são derivados da via do MVA e MEP extraídos de plantas, onde cumprem diversos papéis funcionais. Os terpenos são encontrados em uma variedade de alimentos, especialmente em frutas, vegetais e óleos. Estes compostos podem interferir em vários pontos da via de síntese de isoprenóides, inibindo a síntese de esteróis e bloqueando a isoprenilação de proteínas (CROWELL et al., 1991; CROWELL; GOULD, 1994).

Os terpenos possuem atividade antibacteriana, antitumoral, antiviral e antifúngica (TATMAN; MO, 2002), além de possuir atividade contra parasitas como P. falciparum, Toxoplasma gondii (EL-SAYED et al., 2001) e Trypanosoma brucei (CALIS et al., 2006). Existem também relatos de atividade de terpenos contra espécies do gênero Leishmania como L. (L.) donovani (CAMACHO et al., 2003) e L. (L.) major (FUCHINO et al., 2001).

Terpenos como farnesol, limoneno e nerolidol têm também atividade inibitória sobre células tumorais (WATTENBERG; COCCIA, 1991) além de atividade antibacteriana (INOUE et al., 2004). O farnesol pode interferir no ciclo celular e induzir apoptose (BURKE et al., 1997) e parece também ter sua atividade 
relacionada à interferência na via dos isoprenóides inibindo a síntese da enzima HMG-CoA redutase ou acelerando sua degradação (MO; ELSON, 2004).

Limoneno possui atividade antibacteriana e antifúngica (AL-BURTAMANI et al., 2005), e inibe o crescimento de células tumorais, além de ser capaz de prevenir o desenvolvimento de tumores (CROWELL, 1997; TSUDA et al., 2004). O mecanismo de ação proposto é a inibição da isoprenilação de proteínas por interferência na via dos isoprenóides (CROWELL et al., 1991; SCHULZ et al., 1994) e alterações na síntese de proteínas Ras (HOLSTEIN; HOHL, 2003). O limoneno é ativo in vitro contra diversas espécies de Leishmania e apresenta também atividade in vivo em infecções murinas por L. (L.) amazonensis (ARRUDA, 2007).

Limoneno é oxidado no fígado sendo seus metabólitos o álcool perílico, aldeído perílico e finalmente ácido perílico (CROWELL; GOULD, 1994). Derivados do limoneno demonstraram ser mais eficientes que o limoneno no tratamento de tumores de mama, produzindo efeitos no crescimento, no ciclo celular e na regulação e expressão de proteínas (YURI et al,2004). Considerando-se a atividade previamente observada de limoneno no tratamento de leishmaniose experimental, justificava-se a investigação sobre a atividade de seus derivados no mesmo modelo.

Assim, a atividade de álcool, aldeído e ácido perílico contra Leishmania foi inicialmente avaliada em culturas in vitro. As concentrações utilizadas foram diferentes para cada tipo de droga tendo como referência as utilizadas para culturas de células neoplásicas. Além disso, foram utilizados tempos de incubação diferentes, com a intenção de determinar qual o tempo de maior atividade. 
Metabólitos do limoneno demonstraram atividade em culturas de promastigotas de L. (L.) major e L. (L.) amazonensis. A sensibilidade das duas espécies aos diferentes compostos foi bastante similar, em termos de valores de $I_{50}$. Para todos os compostos, houve incremento da atividade quando comparados os tempos de incubação de 2 e 24 horas, enquanto que o prolongamento do tempo de incubação para 48 horas não induziu aumento importante de atividade. $\mathrm{O}$ valor de $\mathrm{IC}_{50}$ determinado para ácido perílico foi bastante alto, em faixa de mM. Álcool perílico apresentou atividade significativa já após 2 horas de incubação, o que nos fez supor que haveria atividade citolitica. De fato, promastigotas tratados com álcool perílico observados ao microscópio óptico mostravam evidências de membranas danificadas ou promastigotas totalmente destruídos (dados não apresentados).

Também testamos a atividade das drogas em amastigotas de lesão de $L$. (L.) amazonensis. Foram utilizados amastigotas desta espécie devido a problemas na obtenção de amastigotas de L. (L.) major, já que as lesões induzidas em camundongos nesse caso são de evolução lenta e contem um número bem mais reduzido de parasitas.

Avaliamos a atividade destas drogas em amastigotas, pois essa é a forma que se apresenta no hospedeiro vertebrado. Os resultados demonstraram que os monoterpenos álcool e aldeído perílicos têm atividade contra amastigotas após tempos de incubação de 24 horas. Os valores de $I_{50}$ obtidos para amastigotas foram comparáveis aos previamente demonstrados para promastigotas. Não observamos atividade dose-dependente de ácido perílico contra amastigotas, em concentrações de até $5 \mathrm{mM}$. 
A citotoxicidade destes compostos foi avaliada em diferentes células

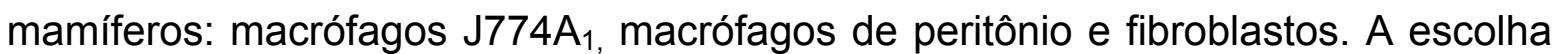
de macrófagos baseou-se em serem essas as células hospedeiras naturais de Leishmania, enquanto os experimentos com linhagem de fibroblastos humanos tinham como objetivo verificar se a alta toxicidade observada com macrófagos era generalizada.

Tanto álcool perílico como aldeído perílico tiveram comportamento similar em culturas de células. Índices de seletividade $\left(\mathrm{CC}_{50} / \mathrm{IC} \mathrm{C}_{50}\right)$ menores que 1 foram obtidos para os dois tipos de macrófagos, mostrando um efeito tóxico das drogas muito severo. Curiosamente, para álcool perílico os dados de literatura apontam para toxicidade leve a moderada após administração por via oral de doses de 1600 a $2800 \mathrm{mg} / \mathrm{m}^{2}$. A determinação dos níveis séricos obtidos após a administração dessas doses não detecta a presença de álcool perílico no plasma, mas sim a de seus derivados, sendo um deles o ácido perílico nas concentrações de $433.2 \pm$ $245.8 \mu \mathrm{M}$ e $774.1 \pm 439.6 \mu \mathrm{M}$ respectivamente (HUDES et al., 2000). monoterpeno álcool perílico nas concentrações empregadas está dentro de faixa de doses utilizadas em humanos.

Para verificar se a toxicidade observada contra macrófagos in vitro era um fenômeno geral, foram então utilizados fibroblastos, que se mostraram menos sensíveis às drogas apresentando IS de 3,28 e 2,85, respectivamente, para álcool e aldeído perílico.

A toxicidade de ácido perílico foi maior para macrófagos do que para parasitas: enquanto mesmo doses de $5 \mathrm{mM}$ levaram a praticamente nenhum efeito em amastigotas, a mesma dose foi capaz de reduzir a viabilidade de macrófagos de maneira drástica. Assim, considerando-se a baixa atividade antiparasitária e alta 
toxicidade de ácido perílico, não foram realizados outros experimentos in vitro ou in vivo com ácido perílico. Além da atividade de álcool e aldeído perílico na inibição da multiplicação dos parasitas cultivados in vitro, foi também testada a atividade em amastigotas intracelulares em culturas de macrófagos $\mathrm{J}_{774 \mathrm{~A}_{1}}$ e macrófagos de peritônio. Observamos reduções de até $40 \%$ no número de células infectadas após tratamento com álcool ou aldeído perílico.

Algumas hipóteses para explicar a baixa eficácia nesses experimentos seriam: embora essas drogas sejam altamente lipofílicas, pode haver baixa penetração no macrófago ou baixas concentrações no vacúolo parasitóforo; as drogas estariam sendo degradadas para outras formas metabólicas pelo macrófago infectado; ou a terceira opção, onde os amastigotas intracelulares seriam mais resistentes a essas drogas.

Curiosamente as atividades de álcool e aldeído perílico foram mais acentuadas conforme o tipo de macrófago utilizado: enquanto álcool perílico foi mais ativo em infecções com macrófagos $\mathrm{J774}$. $\mathrm{A}_{1}$, aldeído mostrou-se mais eficaz quando as infecções foram realizadas em macrófagos de peritônio. Essas observações podem ser sugestivas de que os dois metabólitos tenham sua ação leishmanicida devida a mecanismos distintos.

Estudos em animais com álcool perílico tinham demonstrado que este monoterpeno pode ser efetivo na prevenção do câncer. Múltiplos estudos feitos por Lantry et al. (1997) mostraram que álcool perílico poderia inibir a iniciação do tumor. Barthelman et al. (1998) demonstraram que esta droga inibia a incidência do tumor e multiplicidade, em modelo murino de câncer de pele. Os derivados do limoneno estão sendo testados em diferentes fases de tratamento e autores como 
Crowel et al. (1997) consideram os metabólitos do limoneno como drogas com características quimiopreventivas.

Com base nesses dados, tentamos então avaliar se haveria um efeito estimulador da atividade microbicida do macrófago induzida por tratamento das culturas de células antes da infecção. Observamos que o pré-tratamento das células com álcool perílico por 24 horas antes da infecção aumentou a atividade anti-Leishmania. Esse efeito não foi observado para aldeído perílico. Como um dos mecanismos antimicrobianos do macrófago mais efetivos contra Leishmania é a produção de NO, o aumento da atividade de álcool perílico administrado antes da infecção poderia estar relacionado a estimulação da produção de NO. Foram então realizadas medidas da acumulação de nitrito em sobrenadantes dessas culturas. Aumento na produção de NO após tratamento com álcool perílico e ácido perílico ou limoneno também não foi detectado em estudos anteriores (DEL TOROARREOLA et al., 2005; ARRUDA, 2007).

Vários estudos em células tumorais relacionam a atividade de álcool perílico a alterações na isoprenilação de proteínas (CROWELL et al., 1991; GELB et al., 1995; HARDCASTLE et al., 1999). Para determinar se a atividade desses monoterpenos contra Leishmania estava relacionada à interferência na síntese de proteínas isopreniladas foram feitos experimentos preliminares. Assim, determinamos as concentrações de droga a serem utilizadas em marcações metabólicas com precursores específicos da via de isoprenóides através de ensaios de viabilidade celular e marcação de proteínas totais.

Não conseguimos demonstrar a ocorrência de isoprenilação de proteínas em experiências realizadas com promastigotas de L. (L.) major marcados com os precursores [1(n)-3H]-farnesil pirofosfato e [1(n)-3H]-geranilgeranil pirofosfato. A 
separação de extratos protéicos marcados com [1(n)-3H]-geranilgeranil pirofosfato permitiu a detecção de radioatividade apenas no limite do gel, que poderia corresponder a precursor não incorporado ou a presença de proteínas com massa molecular aparente menor que 12 kDa. Após marcação com [1(n)-3H]-farnesil pirofosfato não foi possível detectar qualquer marcação em proteínas totais. Esses experimentos foram repetidos várias vezes, obtendo-se sempre os mesmos resultados.

A análise dos dados do genoma de $L$. (L.) major revela a presença de vários genes que codificam proteínas contendo em sua seqüência sítios aceptores de isoprenilação (FIELD et al., 1996) (dados não apresentados). A maioria desses genes codificam proteínas de 21 a 28 kDa. Portanto, esperávamos identificar produtos marcados nessa faixa de massa. D'Alexandri et al. (2006) relataram a presença de proteínas isopreniladas com massa na faixa de 5 a $8 \mathrm{kDa}$ em $P$. falciparum, sugerindo que as manchas na base do gel de promastigotas de $L$. (L.) major poderiam ser proteínas isopreniladas de baixo peso molecular. Portanto, esse fenômeno ainda precisa ser melhor investigado. Com os resultados disponíveis, não é possível explicar a ausência de marcação de proteínas na faixa de $20 \mathrm{kDa}$, tanto com [1(n)-3H]-farnesil pirofosfato como com [1(n)-3H]geranilgeranil pirofosfato.Vale a pena ressaltar que esses precursores são eficientemente incorporados por promastigotas de Leishmania resultando na síntese de diversos compostos isoprênicos, como demonstrado em trabalhos anteriores (ARRUDA et al., 2005; ARRUDA, 2007).

As proteínas isopreniladas têm importantes funções reguladoras, pertencem ao grupo das pequenas proteínas G (PGP), envolvidas em uma variedade de sinais relativos ao crescimento, diferenciação, organização do citoesqueleto e 
transporte vesicular. As funções das PGP dependem da modificação póstraducional (MCTAGGART, 2006), que resulta na adesão de grupos prenil que ancoram as pequenas $G$ proteínas às membranas intracelulares (MAGEE; MARSHALL, 1999).

As PGP são proteínas monoméricas, que compreendem a superfamília Ras, que por sua vez inclui famílias estruturalmente classificadas: Ras, Rho/Rac, Rab, Sar1/Arf e Ran (BUSS et al., 1991). Dentro da família Ras esta a P21 Ras, expressa em numerosos tecidos e ativada por diversos fatores e sinais extracelulares (JACKSON et al., 1990; VOJTEK; DER, 1998).

Sabe-se que espécies de Leishmania são capazes de sintetizar esteróis utilizando a via do mevalonato (BERMAN et al., 1984). Ellis et al. (1994) caracterizaram a molécula de ubiquinona desses parasitas e a síntese de dolicol foi caracterizada em L. (L.) amazonensis por Arruda et al. (2005).

O processo de prenilação de proteínas em Leishmania não foi estudado, mas existem trabalhos feitos com Trypanosoma brucei que mostram que a inibição de PFTase afetaria a síntese de proteínas isopreniladas (FIELD et al., 1996; YOKOYAMA et al., 1997). Proteínas isopreniladas foram também detectadas em Trypanosoma cruzi e Leishmania donovani (CASSEL et al., 1991) quando essas células foram marcadas com ácido mevalônico radioativo. A incorporação de FPP e GGPP marcados em proteínas de Leishmania nunca foi demonstrada.

Tendo verificado a atividade in vitro dos derivados do limoneno, passamos a avaliar a atividade in vivo destes dois monoterpenos. Testes de fase I realizados com álcool perílico relataram moderada toxicidade em dose crônicas com efeitos gastrointestinais (náusea, vomito, anorexia, saciedade, eructação e gosto desagradável) e fadiga (RIPPLE et al. 2000). Entretanto, não existem dados sobre 
a toxicidade de aldeído perílico. Os testes de tolerância em camundongos com ambos os compostos, administrados por via tópica ou intra-retal, não mostraram sinais de toxicidade tomando como parâmetros o local da aplicação, estado da pelagem, peso e irritabilidade. Podemos afirmar que estas drogas nas concentrações, freqüência e vias de aplicação utilizada nos camundongos infectados com as duas espécies de Leishmania, não apresentaram sinais de toxicidade significativa. No tratamento de leishmaniose cutânea, o desenvolvimento de um medicamento que possa ser utilizado por via tópica seria um grande avanço. Por isso, utilizamos essa via em testes iniciais de eficácia de álcool perílico. Entrentanto, o tratamento de camundongos BALB/C infectados com L. (L.) amazonensis ou L. (L.) major com álcool perílico por via tópica não foi eficaz.

Os resultados negativos desses experimentos nos levaram a considerar que o curto tempo de exposição da lesão às drogas poderia ser um limitante forte, já que os camundongos rapidamente removem o creme da cauda por contato com a serragem ou por lambidas. Além disso, temos o problema que os derivados do limoneno são rapidamente metabolizados pelo fígado de mamíferos, sendo encontrados no plasma sanguíneo após 15 minutos de consumo por via oral, com um pico de acúmulo após 1-3 horas, sendo a meia vida de 2 horas (RIPPLE et al., 2000), fortalecendo a idéia da chegada mínima da droga na célula infectada.

Isso significa que álcool perílico estaria sendo degradado a aldeído perílico, que é rapidamente metabolizado dentro do organismo e passado a ácido perílico, o metabólito mais abundante. No entanto, o ácido perílico é, como demonstramos, menos ativo contra Leishmania (experimentos in vitro). Portanto, não se teria a concentração necessária para matar as formas amastigotas encontradas no macrófago de camundongos BALB/c infectados. 
A via de administração intra-retal, que havia se mostrado eficiente no tratamento com limoneno (ARRUDA, 2007), poderia evitar, pelo menos parcialmente, a metabolização rápida dessas drogas, já que os produtos absorvidos pela mucosa do reto não são imediatamente levados ao fígado, evitando-se o metabolismo de primeira passagem. Contudo, o tratamento de camundongos com álcool perílico por essa via também não foi eficaz.

Estes resultados se repetiram com aldeído perílico que, sendo avaliado nas mesmas concentrações de álcool perílico não apresentou efeito sobre L. (L.) amazonensis, motivo pelo qual aumentamos a freqüência para os camundongos infectados com L. (L.) major, tentando manter os níveis deste metabólito no plasma sanguíneo, mas os resultados se mantiveram negativos tanto para via tópica quanto por via intra-retal.

Tentamos também utilizar a associação de álcool perílico e aldeído perílico para o tratamento de camundongos infectados com Leishmania. Essas duas drogas combinadas por via tópica não demonstraram atividade quando foi utilizada a associação por via intraperitoneal observamos melhora nos camundongos tratados em comparação com os não tratados. Tentamos então avaliar doses mais altas que se mostraram tóxicas para os camundongos BALB/c. Assim não foi possível concluir o experimento devido à morte da metade dos camundongos na primeira semana de tratamento.

As doses testadas in vivo nesse trabalho foram inferiores às utilizadas em estudos para o tratamento de câncer. Entretanto, existem exemplos na literatura de administração de compostos em altas doses em preparações liquidas (MIYAGI et al., 2000; PORRINI et al., 2005) com atividade antineoplásica. Por isso que mesmo em doses elevadas e escapando das medidas usuais a serem tomadas para 
considerar uma droga efetivamente viável, seguimos em frente com os experimentos, já que esses terpenos poderiam ser agregados a diferentes bebidas nas concentrações necessárias para curar a doença.

Podemos sugerir também, que ante a atividade in vitro contra promastigotas e amastigotas extracelulares e a pouca eficácia da droga in vivo na inibição de amastigotas intracelulares em camundongos infectados é possível que a membrana do macrófago represente a barreira para entrada da droga. $\mathrm{O}$ encapsulamento desses terpenos em liposomos ou microcápsulas poderia ajudar no problema da chegada ao interior do macrófago e evitar a degradação das drogas por enzimas hepáticas. Assim trabalhos feitos por Bertolini et al. (2001) relataram a tentativa de encapsular o monoterpeno limoneno em goma arábica, tendo-se observado a pouca estabilidade, permitindo a oxidação a outros metabólitos. Assim a busca de membranas com permeabilidade seletiva para evitar a oxidação de monoterpenos se faz necessária para melhor conhecimento da atividade destes terpenos.

Assim, podemos concluir que os composto álcool perílico e aldeído perílico apresentam atividade in vitro contra promastigotas e amastigotas axênicos, enquanto ácido perílico não foi capaz de reduzir apropriadamente o crescimento deste protozoário.

Estes terpenos mostraram-se tóxicos para células de mamíferos in vitro, mas foram bem tolerados in vivo em doses de até $2 \mathrm{~g} / \mathrm{Kg} /$ dia em camundongos BABL/c. Não houve resposta clínica à administração de álcool e aldeído perílico em camundongos infectados com L. (L) major ou L. (L.) amazonensis e tratados por via tópica, intra-retal ou intraperitoneal. 
A associação de álcool e aldeído perílico por via intra-retal em altas doses foi capaz de retardar a progressão da doença em camundongos infectados com $L$. (L.) amazonensis.

Os resultados obtidos nesse trabalho podem fornecer bases para estudos de modificação das moléculas de limoneno e de seus derivados metabólicos, buscando encontrar moléculas que retenham a atividade antiparasitária, mas que apresentem menor toxicidade e melhores propriedades de penetração tecidual e concentração no macrófago. 


\section{REFERENCIA BIBLIOGRAFICA}

ABRAMSON, M. A.; DIETZE, R.; FRUCHT, D. M.; SCHWANTZ, R.; KENNEY, R. T. Comparison of new and old-world leishmanins in an endemic region of Brazil. Clin. Infect. Dis., v. 20, n. 5, p. 1292-1297, 1995.

ADLER, S.; THEODOR, O. Transmission the disease agents by phlebotomine sandflies. Annu. Rev., v. 2, p. 203-226, 1957.

AL-BURTAMANI, S. K.; FATOPE, M. O.; MARWAH, R. G.; ONIFADE, A. K.; AL-SAIDI, S. $\mathrm{H}$. Chemical composition, antibacterial and antifungal activities of the essential oil of haplophyllum tuberculatum from oman. J. Ethnopharmacol., v. 96, n. 1-2, p. 107-112, 2005.

ALBERTS, B.; BRAY, D.; JOHNSON, A.; LEWIS, J.; RAFF, M.; ROBERTS, K.; WALTER, P. Essential Cell Biology. In: . [S.I.]: Garland Publishing, 1998. cap. Energy Generation in Mitochondria and Chloroplasts, p. 407-446.

ARRUDA, D. C. Caracterização da atividade leishmanicida de nerolidol e limoneno e da interferência desses terpenos na biossíntese de isoprenóides. Tese (Doutorado) Instituto de Ciências Biomédicas da Universidade de São Paulo, 2007.

ARRUDA, D. C.; ALEXANDRI, F. L. D.; KATZIN, A. M.; ULIANA, S. R. Antileishmanial activity of the terpene nerolidol. Antimicrob. Agents Chemother., v. 49, n. 5, p. 16791687, 2005.

ASHFORD, R. W. The leishmaniases as emerging and reemerging zoonoses. Inter. J. Parasitol., v. 30, n. 12-13, p. 1269-1281, 2000.

BAILY, G. G.; NANDY, A. Visceral leishmaniasis: more prevalent and more problematic. J. Infect., v. 29, n. 3, p. 241-247, 1994.

BALANA-FOUCE, R.; REGUERA, R. M.; CUBRIA, J. C.; ORDONEZ, D. The pharmacology of leishmaniasis. Gen. Pharmacol., v. 30, n. 3, p. 241-247, 1998.

BALESTIERI, F. M.; QUEIROZ, A. R.; SCAVONE, C.; COSTA, V. M.; BARRAL-NETTO, M.; ABRAHAMSOHN, A. Leishmania $(L)$ amazonensis-induced inhibition of nitric oxide synthesis in host macrophages. Microbes Infect., v. 4, n. 1, p. 23-29, 2002.

BARBACID, M. Ras genes. Annu. Rev. Biochem., v. 56, n. 1, p. 779-827, 1987.

BARRAL-NETTO, M.; BARRAL, A.; BROWNELL, C. E.; SKEIKY, Y. A.; ELLINGSWORTH, L. R.; TWARDZIK, D. R.; REED, S. G. Transforming growth factor-beta in leishmanial infection: a parasite escape mechanism. Sciences., v. 257, n. 5069, p. 545-548, 1992.

BARTHELMAN, M.; CHEN, W.; GENSLER, H. L.; HUANG, C.; DONG, Z.; BOWDEN, G. T. Inhibitory effects of perillyl alcohol on uvb-induced murine skin cancer and ap-1 transactivation. Cancer Res., v. 58, n. 4, p. 711-716, 1998. 
BASSELIN, M.; BADET-DENISOT, M. A.; ROBERT-GERO, M. Modification of kinetoplast dna minicircle composition in pentamidine-resistant Leishmania. Acta Trop., v. 70, n. 1, p. 43-61, 1998.

BASSELIN, M.; DENISE, H.; COMMBS, G. H.; BARRET, M. P. Resistance to pentamidine in Leishmania mexicana involves exclusion of the drug from the mitochondrion. Antimicrob. Agents Chemother., v. 46, n. 12, p. 3731-3738, 2002.

BATES, P. A. The developmental biology of Leishmania promastigotes. Exp. Parasitol., v. 79, n. 2, p. 215-218, 1994.

BEACH, D. H.; GOAD, L. J.; HOLZ, G. G. J. Effects of antimycotic azoles on growth and sterol biosynthesis of Leishmania promastigotes. Mol. Biochem. Parasitol,, v. 31, n. 2, p.149-162, 1998.

BERMAN, J. D. Efficacy and safety of liposomal amphotericin b (ambisome) for visceral leishmaniasis in endemic developing countries. Bull. World Health Organ., v. 76, n. 1, p. 25-32, 1998.

BERMAN, J. D.; EDWARDS, N.; KING, M.; GROGL, M. Biochemistry of pentostam resistant Leishmania. Am. J. Trop. Med., Hyg., v. 2, n. 40, p. 159-164, 1989.

BERMAN, J. D.; GALLALEE, J. V.; BEST, J. M. Sodium stibogluconate (pentostam) nhibition of glucose catabolism via the glycolytic pathway, and fatty acid beta-oxidation in Leishmania mexicana amastigotes. Biochem. Pharmacol., v. 36, n. 2, p. 197-201, 1987.

BERMAN, J. D.; GOAD, L. J.; BEACH, D. H.; HOLZ, G. G. J. Effects of ketoconazole on sterol biosynthesis by leishmania mexicana mexicana amastigotes in murine macrophage tumor cells. Mol. Biochem. Parasitol., v. 20, n. 1, p. 85-92, 1986.

BERMAN, J. D.; HOLZ, G. G. J.; BEACH, D. H. Effects of ketoconazole on growth and sterol biosynthesis of Leishmania mexicana promastigotes in culture. Mol. Biochem. Parasitol., v. 12, n. 1, p. 1-13, 1984.

BERTOLINI, A. C.; SIANI, A. C.; GROSSO, C. R. Stability of monoterpenes encapsulated in gum arabic by spray-drying. J. Agric. Food Chem., v. 49, n. 2, p. 780-785, 2001.

BHATTACHARYA, S. K.; JHA, T.; SUNDAR, S.; THAKUR, C. P.; ENGEL, J.; SINDERMANN, H.; JUNGE, K.; KARBWANG, J.; BRYCESON, A.; BERMAN, J. Efficacy and tolerability of miltefosine for childhood visceral leishmaniasis in india. Clin. Infect. Dis., v. 38, n. 2, p. 217-221, 2004.

BHATTACHARYA, S. K.; SINHA, P. K.; SUNDAR, S.; THAKUR, C. P.; JHA, T. K.; PANDEY, K.; DAS, V. R.; KUMAR, N.; LAL, C.; VERMA, N.; SINGH, V. P.; RANJAN, A.; VERMA, R. B.; ANDERS, G.; SINDERMANN, H.; GANGULY, N. K. Phase 4 trial of miltefosine for the treatment of indian visceral leishmaniasis. J. Infect. Dis., v. 196, n. 4, p. 591-598, 2007.

BRAY, P. G.; BARRETT, M. P.; WARD, S. A.; DE-KONING, H. P. Pentamidine uptake and resistance in pathogenic protozoa: past, present and future. Trends Parasitol., v. 19, n. 5, p. 232-239, 2003.

BROITMAN, S. A.; WILKINSON, J. t.; CERDA, S.; BRANCH, S. K. Effects of monoterpenes and mevinolin on murine colon tumor ct-26 in vitro and its hepatic metastases in vivo. Adv. Exp. Med. Biol., v. 401, p. 111-130, 1996. 
BRYCESON, A. Visceral leishmaniasis in india. Lancet., v. 356, p. 1933, 2000.

BURKE, Y. D.; STARK, M. J.; ROACH, S. L.; SEN, S. E.; CROWELL, P. L. Inhibition of pancreatic cancer growth by the dietary isoprenoids farnesol and geraniol. Lipids., v. 32, n. 2, p. 151-159, 1997.

BUSS, J.; QUILLIAM, L.; KATO, K.; CASEY, P. J.; SOLSKI, P. A.; WONG, G.; WONG, G.; CLARK, R.; MCCCORMICK, F.; BOCOCH, G. M.; DER, C. J. The cooh-terminal domain of the rap1a (krev-1) protein is isoprenylated and supports transformation by an h-ras:rap1a chimeric protein. Mol. Cell Biol., v. 11, n. 3, p. 1523-1530, 1991.

CALIS, I.; KOYUNOGLU, S.; YESILADA, A.; BRUN, R.; RUEDI, P.; TASDEMIR, D. Antitrypanosomal cycloartane glycosides from astragalus baibutensis. Chem. Biodivers., v. 3,n. 8, p. 923-929, 2006.

CAMACHO, M. R.; PHILLIPSON, J. D.; CROFT, S. L.; SOLIS, P. N.; MARSHALL, S. J.; GHAZANFAR, S. A. Screening of plant extracts for antiprotozoal and cytotoxic activities. J. Ethnopharmacol., v. 89, n. 2-3, p. 185-191, 2003.

CAMARGO, M. M.; ANDRADE, A. C.; ALMEIDA, I. C.; TRAVASSOS, L. R.; GAZZINELLI, R. T. Glycosylphosphatidylinositol-anchored mucin-like glycoproteins isolated from Trypanosoma cruzi trypomastigotes initiate the synthesis of proinflammatory cytokines by macrophages. J. Immunol., v. 159, n. 12, p. 6131-6139, 1997.

CASEY, P. J.; SEABRA, M. C. Protein prenyltransferases. J. Biol. Chem., v. 271, n. 10, p. 5289-5292, 1996.

CASEY, P. J.; SOLSKI, P. A.; DER, C. J.; BUSS, J. E. p21ras is modified by a farnesil isoprenoid. Proc. Natl. Acad. Sci. U.S.A., v. 86, n. 21, p. 8323-8327, 1989.

CASSEL, D.; SHOUBI, S.; GLUSMAN, G.; CUKIERMAN, E.; ROTMAN, M.; ZILBERSTEIN, D. Leishmania donovani: characterization of a 38-kda membrane protein that cross-reacts with the mammalian g-protein transducin. Exp. Parasitol., v. 72, n. 4, p. 411-417, 1991.

CERDA, S. R.; WILKINSON, J. t.; BRANCH, S. K.; BROITMAN, S. A. Enhancement of sterol synthesis by the monoterpene perillyl alcohol is unaffected by competitive 3-hydroxy3-methylglutaryl coa reductase inhibition. Lipids., v. 34, n. 6, p. 605-615, 1999.

CHEN, G. Z.; BENNETT, J. L. Characterization of mevalonate-labeled lipids isolated from parasite proteins in schistosoma mansoni. Mol. Biochem. Parasitol., v. 59, n. 2, p. 287292, 1993.

CHEN, H.; CHAN, K. K.; BUDD, T. Pharmacokinetics of d-limonene in the rat by gc-ms assay. J. Pharm. Biomed. Anal., v. 17, n. 4-5, p. 631-640, 1998.

CHEN, X.; YANO, Y.; HASUMA, T.; YOSHIMATA, T.; YINNA, W.; OTANI, S. Inhibition of farnesyl protein transferase and p21ras memebrane association by d-limonene in human pancreas tumor cells in vitro. Chin. Med. Sci. J., v. 14, n. 3, p. 138-144, 1999.

CHOW, H. H.; SALAZAR, D.; HAKIM, I. A. Pharmacokinetics of perillic acid in humans after a single dose administration of a citrus preparation rich in d-limonene content. Cancer Epidemiol. Biomarkers Prev., v. 11, p. 1472-1476, 2002.

CONTE, J. J. Pharmacokinetics of intravenous pentamidine in patients with normal renal function or receiving hemodialysis. J. Infect. Dis., v. 163, n. 1, p. 169-175, 1991. 
CROFT, S.; YARDLEY, V. Chemotherapy of leishmaniasis. Curr. Pharm. Des., v. 8, n. 4, p. 319-342, 2002.

CROFT, S. L.; COOMBS, G. H. Leishmaniasis - current chemotherapy and recent advances in the search for novel drugs. Trends Parasitol., v. 19, n. 11, p. 502-508, 2003.

CROFT, S. L.; SUNDAR, S.; FAIRLAMB, A. H. Drug resistance in leishmaniasis. Clin. Microbiol., Rev., v. 19, n. 1, p. 111-126, 2006.

CROWELL, P. L. Monoterpenes in breast cancer chemoprevention. Breast Cancer Res. Treat., v. 46, n. 2-3, p. 191-197, 1997.

CROWELL, P. L.; CHANG, R. R.; REN, Z. B.; ELSON, C. E.; GOULD, M. N. Selective inhibition of isoprenylation of 21-26-kda proteins by the anticarcinogen d-limonene and its metabolites. J. Biol. Chem., v. 266, n. 26, p. 17679-17685, 1991.

CROWELL, P. L.; GOULD, M. N. Chemoprevention and therapy of cancer by d-limonene. Crit. Ver. Oncog., v. 5, n. 1, p. 1-22, 1994.

CUNNINGHAM, A. C. Parasitic adaptive mechanisms in infection by leishmania. Exp. Mol. Pathol., v. 2, n. 72, p. 132-141, 2002.

CUNNINGHAM, M. L.; FAIRLAMB, A. H. Trypanothione reductase from leishmania donovani. purification, characterisation and inhibition by trivalent antimonials. Eur. J. Biochem., v. 230, n. 2, p. 460-468, 1995.

CUNNINGHAM, M. L.; ZVELEBIL, M. J.; FAIRLAMB, A. H. Mechanism of inhibition of trypanothione reductase and glutathione reductase by trivalent organic arsenicals. Eur. J. Biochem., v. 221, n. 1, p. 285-295, 1994.

D'ALEXANDRI, F. L.; KIMURA, E. A.; PERES, V. J.; KATZIN, A. M. Protein dolichylation in plasmodium falciparum. FEBS Lett., v. 580, n. 27, p. 6343-6348, 2006.

DAVIDSON, R. N.; MARTINO, L. D.; GRADONI, L.; GIACCHINO, R.; RUSSO, R.; GAETA, G. B.; PEMPINELLO, R.; SCOTT, S.; RAIMONDI, F.; CASCIO, A. Liposomal amphotericin b (ambisome) in mediterranean visceral leishmaniasis: a multi-centre trial. Q. J. Med., v. 87, n. 2, p. 75-81, 1994.

DEL TORO-ARREOLA, S.; FLORES-TORRALES, E.; TORRES-LOZANO, C.; DEL TOROARREOLA, A.; TOSTADO-PELAYOL, K.; GUADALUPE, R. M, DANERI-NAVARRO, A. Effect of Dlimonene on immune response in BALB/c mice with lymphoma. Int. Immunopharmacol. , v. 5 , n. 5 , p. $829-838$.

DESJEUX, P. The increase in risk factors for leishmaniasis worldwide. Trans. R. Soc. Trop. Med. Hyg., v. 95, n. 3, p. 239-243, 2001.

DING, A.; NATHAN, C. F.; GRAYCAR, J.; DERYNCK, R.; STUEHR, D. J.; SRIMAL, S. Macrophage deactivating factor and transforming growth factors-beta 1 -beta 2 and -beta 3 inhibit induction of macrophage nitrogen oxide synthesis by ifn-gamma. J. Immunol., v. 143, n. 3, p. 940-944, 1990.

DO SOCORRO, S. R.; MDO, S.; MENDONCA-FILHO, R. R.; BIZZO, H. R.; RODRIGUES, I. de A.; SOARES, R. M.; SOUTO-PADRON, T.; ALVIANO, C. S.; LOPES, A. 
Antileishmanial activity of a linalool-rich essential oil from croton cajucara. Antimicrob. Agents. Chemother., v. 47, n. 6, p. 1895-1901, 2003.

DRAGSTED, L. O.; STRUBE, M.; LETH, T. Dietary levels of plant phenols and other nonnutritive components: could they prevent cancer? Eur. J. Cancer Prev., v. 6, n. 6, p. 552-528, 1997.

DUBEY, V. S.; BHALLA, R.; LUTHRA, R. An overview of the non-mevalonate pathway for terpenoid biosynthesis in plants. J. Biosci. Bioeng., v. 28, n. 5, p. 637-646, 2003.

EL-ON, J.; HALEVY, S.; GRUNWALD, M. H.; WEINRAUCH, L. Topical treatment of old world cutaneous leishmaniasis caused by leishmania major: a double-blind control study. $\mathbf{J}$. Am. Acad. Derma., v. 27, n. 2, p. 227-231, 1992.

EL-SAYED, K. A.; HAMANN, M. T.; HASHISH, N. E.; SHIER, W. T.; KELLY, M.; KHAN, A. A. Antimalarial and antiviral and and antitoxoplasmosis norsesterterpene peroxide acids from the red sea sponge diacarnus erythraeanus. J. Nat. Prod., v. 64, n. 4, p. 522-524, 2001.

ELLIS, J. E.; SETCHELL, K. D.; KANESHIRO, E. S. Detection of ubiquinone in parasitic and free-living protozoa and including species devoid of mitochondria. Mol. Biochem. Parasitol., v. 65, n. 2, p. 213-324, 1994.

FERRI, N.; ARNABOLDI, L.; ORLANDI, A.; YOKOYAMA, K.; GREE, R.; GRANATA, A.; HACHEM, A.; PAOLETTI, R.; GELB, M. H.; CORSINI, A. Effect of s(-) perillic acid on protein prenylation and arterial smooth muscle cell proliferation. Biochem. Pharmacol., v. 62, n. 12, p. 1637-1645, 2001.

FIELD, H.; BLENCH, I.; CROFT, S.; FIELD, M. C. Characterisation of protein isoprenylation in procyclic form trypanosoma brucei. Mol. Biochem. Parasitol., v. 82, n. 1, p. 67-80, 1996.

FREZARD, F.; DIMICHELI, C.; FERREIRA, C.; COSTA, M. A. Glutathione-induced conversion of pentavalent antimony to trivalent antimony in meglumine antimoniate. Antimicrob. Agents Chemother., v. 45, n. 3, p. 913-916, 2001.

FUCHINO, H.; KOIDE, T.; TAKAHASHI, M.; SEKITA, S.; M., S. New sesquiterpene lactones from elephantopus mollis and their leishmanicidal activities. Planta med., v. 67, n. 7, p. 647-653, 2001.

FURTADO, T. A. Doenças Infecciosas com Manifestações Dermatológicas. In:Rio de Janeiro: Editora Médica e Científica, 1994. cap. Leishmaniose, p. 319-338.

GANTT, K. R.; GOLDMAN, T. L.; MCCORMICK, M. L.; MILLER, M.; JERONIMO, S. M. B.; NASCIMENTO, E.; BRITIGAN, B.; WILSON, M. Oxidative responses of human and murine macrophages during phagocytosis of leishmania chagasi. J. Immunol., v. 167, n. 2, p. 893-901, 2001.

GELB, M.; TAMANOI, F.; YOKOYAMA, K.; ESSON, K. The inhibition of protein prenyltransferases by oxygenated metabolites of limonene and perillyl alcohol. Cancer Lett., v. 91, n. 2, p. 169-175, 1995.

GRIMALDI, G. J.; TESH, R. B. Leishmaniasis of the new world: current concepts and implications for future research. Clin. Microbiol. Rev., v. 6, n. 3, p. 230-250, 1993. GRUNLER, J.; ERICSSON, J.; DALLNER, G. Branch-point reactions in the biosynthesis of 
cholesterol, dolichol, ubiquinone and prenylated proteins. Biochim. Biophys. Acta., v. 1212, n. 3, p. 259-277, 1994.

HAAG, D.; GOULD, M. N. Mammary carcinoma regression induced by perillyl alcohol a hydroxylated analog of limonene. Cancer Chemother. Pharmacolog., v. 34, n. 6, p. 477483, 1994.

HAIMEUR, A.; OUELLETTE, M. Gene amplification in leishmania tarentolae selected for resistance to sodium stibogluconate. Antimicrob. Agents Chemother., v. 42, n. 7, p. 1689- 1694, 1998.

HARBORNE, J. B. Role of secondary metabolites in chemical defence mechanisms in plants. Ciba Found. Symp., v. 154, p. 126-139, 1990.

HARDCASTLE, I. R.; ROWLANDS, M. G.; BARBER, A. M.; GRIMSHAW, R. M.; MOHAN M. K. NUTLEY, B. P.; JARMAN, M. Inhibition of protein prenylation by metabolites of limonene. Biochem. Pharmacol., v. 57, n. 7, p. 801-809, 1999.

HARRIS, C. M.; POULTER, C. D. Recent studies of the mechanism of protein prenylation. Nat. Prod. Rep., v. 17, n. 2, p. 137-144, 2000.

HART, D. T.; LAUWERS, W. J.; WILLEMSENS, G.; VANDEN-BOSSCHE, H.; OPPERDOES, F. R. Perturbation of sterol biosynthesis by itraconazole and ketoconazole in leishmania mexicana mexicana infected macrophages. Mol. Biochem. Parasitol., v. 33, n. 2, p. 123-134, 1989.

HAY, R. J. Liposomal amphotericin b, ambisome. J. Infect., v. 28, n. 1, p. 35-43, 1994. HE, L.; MO, H.; HADISUSILO, S.; QURESHI, A. A.; ELSON, C. E. Isoprenoids suppress the growth of murine b16 melanomas in vitro and in vivo. J. Nutr., v. 127, n. 5, p. 668-674, 1997.

HENTZE, B.; KOBAYASHI, T. The estructural changes of leishmania tropica after treatment with pentamide. Ann. Trop. Med. Parasitol., v. 7, n. 2, p. 157-166, 1977.

HEPBURN, N. C. Cutaneous leishmaniasis. Clin. Exp. Dermatol., v. 25, n. 5, p. 363-370, 2000.

HERWALDT, B. L. Leishmaniasis. Lancet., v. 354, n. 9185, p. 1191-1199, 1999.

HOLSTEIN, S. A.; HOHL, R. J. Monoterpene regulation of ras and ras-related protein expression. J. Lipid. Res., v. 44, n. 6, p. 1209-1215, 2003.

HUDES, G. R.; SZARKA, C. E.; ADAMS, A.; RANGANATHAN, S.; MCCAULEY, R.; WEINER, L. M.; LANGER, C. J.; LITWIN, S.; YESLOW, G.; HALBERR, T.; QIAN, M.; GALLO, J. Phase i pharmacokinetic trial of perillyl alcohol (nsc 641066) in patients with refractory solid malignancies. Clin. Cancer Res., v. 6, n. 8, p. 3071-3080, 2000.

INGLESE, J.; GLICKMAN, J. F.; LORENZ, W.; CARON, M. G.; LEFKOWITZ, R. J. Isoprenylation of a protein kinase. requirement of farnesylation/alpha-carboxyl methylation for full enzymatic activity of rhodopsin kinase. J. Biol. Chem., v. 267, n. 3, p. 1422-1425, 1992.

INOUE, Y.; SHIRAISHI, A.; HADA, T.; HIROSE, K.; HAMASHIMA, H.; SHIMADA, J. The antibacterial effects of terpene alcohols on staphylococcus aureus and their mode of action. FEMS. Microbiol. Lett., v. 237, n. 2, p. 325-331, 2004. 
JACKSON, J. H.; COCHRANE, C. G.; BOURNE, J. R.; SOLSKI, P. A.; BUSS, J. E.; DER, C. J. Farnesol modification of kirsten-ras exon $4 \mathrm{~b}$ protein is essential for transformation. Proc. Natl. Acad. Sci., v. 87, n. 8, p. 3042-3046, 1990.

JAMES, G. L.; GOLDSTEIN, J. L.; PATHAK, R. K.; ANDERSON, R. G.; BROWN, M. S. Pxf, a prenylated protein of peroxisomes. J. Biol. Chem., v. 269, n. 19, p. 14182-14190, 1994.

JOMAA, H.; WIESNER, J.; SANDERBRAND, S.; ALTINCICEK, B.; WEIDEMEYER, C.; HINTZ, M.; TURBACHOVA, I.; EBERL, M.; ZEIDLER, J.; LICHTENTHALER, H. K.; SOLDATI, D.; BECK, E. Inhibitors of the nonmevalonate pathway of isoprenoid biosynthesis as antimalarial drugs. Science., v. 285, n. 5433, p. 1573-1576, 1999.

KANDPAL, M.; FOUCE, R. B.; PAL, A.; GURU, P. Y.; TEKWANI, B. L. Kinetics and molecular characteristics of arginine transport by leishmania donovani promastigotes. Mol. Biochem. Parasitol., v. 71, n. 2, p. 193-201, 1995.

KANE, M. M.; MOSSER, D. M. Leishmania parasites and their ploys to disrupt macrophage activation. Curr. Opin. Hematol., v. 7, n. 1, p. 26-31, 2000.

KHAW, M.; PANOSIAN, C. B. Human antiprotozoal therapy: past, present, and future. Clin. Microbiol. Rev., v. 8, n. 3, p. 427-439, 1995.

KILLICK-KENDRICK, R. The biology and control of phlebotomine sand flies. Clin. Dermatol., v. 17, n. 3, p. 279-289, 1999.

KIUCHI, F.; ITANO, Y.; UCHIYAMA, N.; HONDA, G.; TSUBOUCHI, A.; NAKAJIMASHIMADA, J.; AOKI, T. Monoterpene hydroperoxides with trypanocidal activity from chenopodium ambrosioides. J. Nat. Prod., v. 65, n. 4, p. 509-512, 2002.

LAEMMLI, U. K. Cleavage of structural proteins during the assembly of the head of bacteriophage. Nature., v. 227, n. 5259, p. 680-685, 1970.

LAINSON, R.; SHAW, J. J. The Leishmaniases in Biology and Medicine. In: London: Academic Press, 1987. cap. Evolution, classification and geographical distribution, $p$. $1-120$.

LANTRY, L. E.; ZHANG, Z.; GAO, F.; CRIST, K. A.; WANG, Y.; KELLOFF, G. J.; LUBET, R. A.; YOU, M. Chemopreventive effect of perillyl alcohol on 4-(methylnitrosamino)- 1-(3pyridyl)-1-butanone induced tumorigenesis in $(\mathrm{c} 3 \mathrm{~h} / \mathrm{hej} \mathrm{x}$ a/j)f1 mouse lung. J. Cell Biochem., v. 27, p. 20-25, 1997.

LEUNG, K. F.; BARON, R.; SEABRA, M. C. Thematic review series: lipid posttranslational modifications. geranylgeranylation of rab gtpases. J. Lipid Res., v. 47, n. 3, p. 467-475, 2006.

LEWIS, D. J.; WARD, R. D. The Leishmaniases in Biology and Medicine. In: London: Academic Press, 1987. cap. Transmission and vectors, p. 235-262.

LOBELL, R. Prenylation of ras gtpase superfamily proteins and their function in immunobiology. Adv. Immunol., v. 68, p. 145-189, 1998.

LUCUMI, A.; ROBLEDO, S.; GAMA, V.; SARAVIA, N. G. Sensitivity of leishmania viannia panamensis to pentavalent antimony is correlated with the formation of cleavable dnaprotein complexes. Antimicrob. Agents Chemother., v. 42, n. 8, p. 1990-1995, 1998. 
LUJÁN, H. D.; MOWATT, M. R.; CHEN, G. Z.; NASH, T. E. Isoprenylation of proteins in the protozoan giardia lamblia. Mol. Biochem. Parasitol., v. 72, n. 1-2, p. 121-127, 1995.

LYMAN, C.; WALSH, T. J. Systemically administered antifungal agents.a review of their clinical pharmacology and therapeutic applications. Drug., v. 44, n. 1, p. 9-35, 1992.

MAAROUF, M.; DE-KOUCHKOVSKY, Y.; BROWN, S.; PETIT, P. X.; ROBERT-GERO, M. In vivo interference of paromomycin with mitochondrial activity of leishmania. Exp. Cell Res., v. 232, n. 2, p. 339-348, 1997.

MAAROUF, M.; LAWRENCE, F.; BROWN, S.; ROBERT-GERO, M. Biochemical alterations n paromomycin-treated leishmania donovani promastigotes. Parasitol. Res., v. 83, n. 2, p. 98-202, 1997.

MAGEE, T.; MARSHALL, C. New insights into the interaction of ras with the plasma membrane. Cell, v. 98, n. 1, p. 9-12, 1999.

MARKELL, E. K.; JOHN, D. T.; KROTOSKI, W. A. Parasitologia Médica. In: . Rio de Janeiro: Guanabara Koogan, 2003. cap. Outros Protozoários que Habitam o Sangue e os Tecidos, p. 115-176.

MARR, J. J. Purine analogs as chemotherapeutic agents in leishmaniasis and american trypanosomiasis. J. Lab. Clin. Med., v. 118, n. 2, p. 111-119, 1991.

MARTIN, M. B.; GRIMLEY, J. S.; LEWIS, J. C.; HEATH, H. T.; BAILEY, B. N.; KENDRICK, H.; YARDLEY, V.; CALDERA, A.; LIRA, R.; URBINA, J. A.; MORENO, S. N.; DOCAMPO, R.; CROFT, S. L.; OLDFIELD, E. Bisphosphonates inhibit the growth of trypanosoma brucei, trypanosoma cruzi, leishmania donovani, toxoplasma gondii, and plasmodium falciparum: a potential route to chemotherapy. J. Med. Chem., v. 44, n. 6, p. 906-916, 2001.

MAUEL, J.; BEHIN, R.; LOUIS, J. Leishmania enriettii: immune induction of macrophage activation in an experimental model of immunoprophylaxis in the mouse. Exp. Parasitol., v. 52 , n. 3, p. 331-345, 1981.

MCCKEROW, J. H. Development of cysteine protease inhibitors as chemotherapy for parasitic diseases: insights on safety, target validation, and mechanism of action. Int. J. Parasitol., v. 29, n. 6, p. 833-837, 1990.

MCGARVEY, D. J.; CROTEAU, R. Terpenoid metabolism. Plant Cell., v. 7, n. 7, p. 10151026, 2005.

MCTAGGART, S. J. Isoprenylated proteins. Cell. Mol. Life Sci., v. 63, n. 3, p. 255-267, 2006.

MEGANATHAN, R. Ubiquinone biosynthesis in microorganisms. FEMS Microbiol. Lett., v. 203, n. 2, p. 131-139, 2001.

MIYAGI, Y.; OM, A. S.; CHEE, K. M.; BENNINK, M. R. Inhibition of azoxymethane-induced colon cancer. Nutr. Cancer, v. 36, n. 2, p. 224-229, 2000.

MO, H.; ELSON, C. Studies of the isoprenoid-mediated inhibition of mevalonate synthesis applied to cancer chemotherapy and chemoprevention. Exp. Biol. Med., v. 229, n. 7, p. 567-585, 2004. 
MOLYNEUX, H. D.; KILLICK-KENDRICK, R. The Leishmaniases in Biology and Medicine. In: London: Academic Press, 1987. cap. Morphology, ultrastrure and life cycles, p. 551582.

MOSMANN, T. Complexity or coherence? cytokine secretion by b cells. Nat. Immunol., v. 1, n. 6, p. 465-456, 2000.

MOURA, I. C.; WUNDERLICH, G.; UHRIG, M. L.; COUTO, A. S.; PERES, V. J.; KATZIN, A. M.; KIMURA, E. A. Limonene arrests parasite development and inhibits isoprenylation of proteins in plasmodium falciparum. Antimicrob. Agents Chemother., v. 45, n. 9, p. 25532558, 2001.

MURRAY, H. W.; BERMAN, J. D.; DAVIES, C. R.; SARAVIA, N. G. Advances in leishmaniasis. Lancet, v. 366, n. 9496, p. 1561-1577, 2005.

NARE, B.; LUBA, J.; HARDY, L. W.; BEVERLEY, S. New approaches to Leishmania chemotherapy: pteridine reductase 1 (ptr1) as a target and modulator of antifolate sensitivity. Parasitology, v. 114, p. 101-110, 1997.

NAVIN, T. R.; ARANA, B. A.; ARANA, F. E.; BERMAN, J. D.; CHAJON, J. F. Placebocontrolled clinical trial of sodium stibogluconate (pentostam) versus ketoconazole for treating cutaneous leishmaniasis in guatemala. J. Infect. Dis., v. 165, n. 3, p. 528-534, 1992.

NELSON, D. J.; LAFON, S. W.; TUTTLE, J. V.; MILLER, W. H.; MILLER, R. L.; KRENITSKY, T. A.; ELION, G. B.; BERENS, R. L.; MARR, J. J. Allopurinol ribonucleoside as an antileishmanial agent. biological effects, metabolism, and enzymatic phosphorylation.

J. Biol. Chem., v. 254, n. 22, p. 11544-11549, 1979.

OLLIARO, P.; BRYCESON, A. D. Practical progress and new drugs for changing patterns of leishmaniasis. Parasitol. Today, v. 9, n. 9, p. 323-328, 1993.

OZ, H. S.; HUANG, H.; WITTNER, M.; TANOWITZ, H. B.; BILEZIKIAN, J. P.; MORRIS, S. A. Evidence for guanosine triphosphate-binding proteins in trypanosoma cruzi. Am. J. Trop. Med. Hyg., v. 50, n. 5, p. 620-631, 1994.

PEARSON, R. D.; SOUSA, A. Q. Clinical spectrum of leishmaniasis. Clin. Infect. Dis., v. 22, n. 1, p. 1-13, 1996.

PEFFLEY, D. M.; GAYEN, A. K. Plant-derived monoterpenes suppress hamster kidney cell 3-hydroxy-3-methylglutaryl coenzyme a reductase synthesis at the post-transcriptional level. J. Nutr., v. 133, n. 1, p. 38-44, 2003.

PEREIRA-LEAL, J. B.; HUME, A. N.; SEABRA, M. C. Prenylation of rab gtpases: molecular mechanisms and involvement in genetic disease. FEBS Lett., v. 498, n. 2-3, p. 197-200, 2001.

PEREIRA-LEAL, J. B.; SEABRA, M. C. The mammalian rab family of small gtpases: definition of family and subfamily sequence motifs suggests a mechanism for functional specificity in the ras superfamily. J. Mol. Biol., v. 301, n. 4, p. 1077-1087, 2000.

PEREZ-VICTORIA, F. J.; SANCHEZ-CANETE, M. P.; SEIFERT, K.; CROFT, S. L.; SUNDAR, S.; CASTANYS, S.; GAMARRO, F. Mechanisms of experimental resistance of 
leishmania to miltefosine: Implications for clinical use. Drug Resist. Updat., v. 9, n. 1-2, p. 26-39, 2006.

PORRINI, M.; RISO, P.; BRUSAMOLINO, A.; BERTI, C.; GUARNIERI, S.; VISIOLI, F. Daily intake of a formulated tomato drink affects carotenoid plasma and lymphocyte concentrations and improves cellular antioxidant protection. Br. J. Nutr., v. 93, n. 1, p. 9399, 2005.

PROUDFOOT, L.; ODONNELL, C. A.; LIEW, F. Y. Glycoinositolphospholipids of leishmania major inhibit nitric oxide synthesis and reduce leishmanicidal activity in murine macrophages. Eur. J. Immunol., v. 25, n. 3, p. 745-750, 1995.

RAKOTOMANGA, M.; BLANC, S.; GAUDIN, K.; CHAMINADE, P.; LOISEAU, P. M. Miltefosine affects lipid metabolism in leishmania donovani promastigotes. Antimicrob. Agents Chemother., v. 51, n. 4, p. 1425-1430, 2007.

RANGANATHAN, G.; MUKKADA, A. J. Ubiquinone biosynthesis in leishmania major promastigotes. Int. J. Parasitol., v. 25, n. 3, p. 279-284, 1995.

RAPHAEL, T. J.; G., K. Immunomodulatory activity of naturally occurring monoterpenes carvone and limonene and and perillic acid. Immunopharmacol. Immunotoxicol., v. 25, n. 2, p. 285-294, 2003.

RAVDIN, J. I. Principles and Practice of Infectious Diseases. In: New york: Churchill Livingstone, 1990. cap. Protozoal Diseases, p. 2035-2130.

REISS, Y.; BROWN, M. S.; GOLDSTEIN, J. L. Divalent cation and prenyl pyrophosphate specificities of the protein farnesyltransferase from rat brain, a zinc metalloenzyme. J. Biol. Chem., v. 267, n. 9, p. 6403-6408, 1992.

REN, Z.; ELSON, C. E.; GOULD, M. N. Inhibition of type i and type ii geranylgeranyl-protein transferases by the monoterpene perillyl alcohol in nih3t3 cells. Biochem. Pharmacol., v. 54, n. 1, p. 113-120, 1997.

REY, L. Parasitologia. In: . [S.I.]: Guanabara Koogan, 2001. cap. Leishmania e Leishmaníases: os parasitos, p. 214-266.

RIPPLE, G. H.; GOULD, M. N.; STEWART, J. A.; TUTSCH, K. D.; ARZOOMANIAN, R. Z.; ALBERTI, D.; FEIERABEND, C.; POMPLUN, M.; WILDING, G.; BAILEY, H. H. Phase I clinical trial of perillyl alcohol administered daily. Clin. Cancer Res., v. 4, n. 5, p. 11591164, 2000.

ROBERTS, L. S.; JANOVY, J. J. foundations of parasitology. In: . New York: McGraw-Hill, 2000. cap. Kinetoplasta: Trypanosomes and their kin, p. 55-81.

RODRIGUES-GOULART, H.; KIMURA, E. A.; PERES, V. J.; COUTO, A. S.; AQUINODUARTE, F. A.; KATZIN, A. M. Terpenes arrest parasite development and inhibit biosynthesis of isoprenoids in plasmodium falciparum. Antimicrob. Agents Chemother., v. 48, n. 7, p. 2502-2509, 2004.

RODRIGUES, N.; BAILEY, B.; MARTIN, M.; OLDFIELD, E.; URBINA, J.; R., D. Radical cure of experimental cutaneous leishmaniasis by the bisphosphonate pamidronate. $\mathbf{J}$. Infect. Dis., v. 186, p. 138-140, 2002. 
ROHMER, M. The discovery of a mevalonate-independent pathway for isoprenoid biosynthesis in bacteria, algae and higher plants. Nat. Prod. Rep., v. 16, n. 5, p. 565-574, 1999.

ROSKOSKI, R. J. Protein prenylation: a pivotal posttranslational process. Biochem. Biophys. Res. Commun., v. 301, n. 1, p. 1-17, 2003.

ROSSI-BERGMANN, B.; MULLER, I.; GODINHO, E. B. Th1 and th2 t-cell subsets are differentially activated by macrophages and b cells in murine leishmaniasis. Infect. Immun., v. 61, n. 5, p. 2266-2269, 1993.

SACKS, D.; KAMHAWI, S. Molecular aspects of parasite-vector and vector-host interactions in leishmaniasis. Annu. Rev. Microbiol., v. 55, p. 453-483., 2001.

SAMUELSON, J. Patologia Estrutural e Funcional. In: . Rio de Janeiro: Guanabara Koogan, 2000. cap. Doenças infecciosas, p. 350-351.

SANDS, M.; KRON, M. A.; B., B. R. Pentamidine: a review. Rev. Infect. Dis., v. 7, n. 5, p. 625-634, 1985.

SCHALLER, H. New aspects of sterol biosynthesis in growth and development of higher plants. Plant Physiol. Biochem., v. 465-476., n. 6, p. 42, 2004.

SCHULZ, S.; BUHLING, F.; ANSORGE, S. Prenylated proteins and lymphocyte proliferation: inhibition by d-limonene related monoterpenes. Eur. J. Immunol., v. 24, p. 301-307, 1994.

SCHWARTZ, E.; HATZ, C.; BLUM, J. New world cutaneous leishmaniasis in travellers. Lancet. Infect. Dis., v. 6, n. 6, p. 342-349, 2006.

SCOTT, P. Ifn-gamma modulates the early development of th1 and th2 responses in a murine model of cutaneous leishmaniasis. J. Immunol., v. 147, n. 9, p. 3149-3155, 1991.

SCOTT, P.; NATOVITZ, P.; COFFMAN, R. L.; PEARCE, E.; SHER, A. Immunoregulation of cutaneous leishmaniasis. $t$ cell lines that transfer protective immunity or exacerbation belong to different t helper subsets and respond to distinct parasite antigens. J. Exp. Méd., v. 168, n. 5 , p. $1675-1684,1988$.

SEAMAN, J.; WILKINSON, R.; JONG, J. D.; WILDE, E. D.; SONDORF, E.; DAVINSON, R. Liposomal amphotericin b (ambisome) in the treatment of complicated kala-azar under field conditions. Clin. Infect., v. 21, n. 1, p. 188-193, 1995.

SERENO, D.; HOLZMULLER, P.; I, C. G. M.; OUAISSI, A.; LEMESRE, J. L. Antimonialmediated dna fragmentation in leishmania infantum amastigotes. Antimicrob. Agents Chemother., v. 45, n. 7, p. 2064-2069, 2001.

SHAW, J. J. The Leishmaniases in Biology and Medicine. In: London.: Academic Press, 1987. cap. Codes for hosts of Leishmania., p. 464-472.

SIEMIENIUK, E.; SKRZYDLEWSKA, E. Coenzyme q10: its biosynthesis and biological significance in animal organisms and in humans. Postepy Hig. Med. Dosw., v. 59, p. 150159, 2005. 
SILVA, E. S.; GONTIJO, C. M. F.; PACHECO, R. S.; FIUZA, V. O. P.; BRAZIL, R. P. Visceral leishmaniasis in the metropolitan region of belo horizonte, state of minas gerais, brazil. Mem. Inst. Oswaldo Cruz, v. 96, n. 3, p. 285-291, 2001.

SINGH, N.; SINGH, R.; SUNDAR, S. Novel mechanism of drug resistance in kala azar field isolates. J. Infect. Dis., v. 188, n. 4, p. 600-607, 2003.

SINGH, R. K.; PANDEY, H. P.; SUNDAR, S. Visceral leishmaniasis (kala-azar): challenges ahead. Indian J. Med. Res., v. 123, n. 3, p. 331-344, 2006.

SOTO, J.; BERMAN, J. Treatment of new world cutaneous leishmaniasis with miltefosine. Trans. R. Soc. Trop. Med. Hyg., v. 100, n. 1, p. 34-40, 2006.

SOUZA, G. F.; YOKOYAMA-YASUNAKA, J. K.; SEABRA, A. B.; MIGUEL, D. C.; OLIVEIRA, M.; ULIANA, S. R. Leishmanicidal activity of primary s-nitrosothiols against leishmania major and leishmania amazonensis: implications for the treatment of cutaneous leishmaniasis. Nitric Oxide, v. 15, n. 3, p. 209-216, 2006.

SUNDAR, D.; PAI, K.; KUMAR, R.; PATHAK-TRIPATHI, K.; GAM, A. A.; RAY M. KENNEY, R. T. Resistance to treatment in kala-azar: speciation of isolates from northeast india. Am. J. Trop. Med. Hyg., v. 65, n. 3, p. 193-196, 2001.

TATMAN, D.; MO, H. Volatile isoprenoid constituents of fruits and vegetables and herbs cumulatively suppress the proliferation of murine b16 melanoma and human hl-60 leukemia cells. Cancer Lett., v. 175, n. 2, p. 129-139, 2002.

THAKUR, C. P.; DEDET, J. P.; NARAIN, S.; PRATLONG, F. Leishmania species, drug unresponsiveness and visceral leishmaniasis in bihar, india. Trans. R. Soc. Trop. Med. Hyg., v. 95, n. 2, p. 187-189, 2001.

THEODOS, C. M.; POVINELLI, L.; MOLINA, R.; SHERRY, B.; TITUS, R. G. Role of tumor necrosis factor in macrophage leishmanicidal activity in vitro and resistance to cutaneous leishmaniasis in vivo. Infect. Immun., v. 59, n. 8, p. 2839-2842, 1991.

TORO-ARREOLA, S. D.; FLORES-TORALES, E.; TORRES-LOZANO, C.; TOROARREOLA, A. D.; TOSTADO-PELAYO, K.; GUADALUPE-RAMIREZ-DUENAS, M.; DANERI-NAVARRO, A. Effect of d-limonene on immune response in balb/c mice with lymphoma. Int. Immunopharmacol, v. 5, n. 5, p. 829-838, 2005.

TSUDA, H.; OHSHIMA, Y.; NOMOTO, H.; FUJITA, K.; MATSUDA, E.; IIGO, M.; TAKASUKA, N.; MOORE, M. A. Cancer prevention by natural compounds. Drug Metab. Pharmacokinet., v. 19, n. 4, p. 245-263, 2004.

ULIANA, S. R.; GOYAL, N.; FREYMULLER, E.; SMITH, D. F. Leishmania: overexpression and comparative structural analysis of the stage-regulated meta 1 gene. Exp. Parasitol., $v$. 92, n. 3, p. 183-191, 1999.

URBINA, J. A. Lipid biosynthesis pathways as chemotherapeutic targets in kinetoplastid parasites. Parasitology., v. 114, p. S91-S99, 1997.

VAN, A. L.; SOUZA, S. C. D. Rho gtpases and signaling networks. Genes Dev., v. 11, n. 18, p. 2295-2322, 1997. 
VERCESI, A. E.; DOCAMPO, R. Ca2+ transport by digitonin-permeabilized Leishmania donovani. effects of ca2+, pentamidine and wr-6026 on mitochondrial membrane potential in situ. Biochem. J., v. 284, n. 2, p. 463-467, 1992.

VIDAL-PUIG, A. J.; MUNOZ-TORRES, M.; JODAR-GIMENO, E.; GARCIA-CALVENTE, C. J.; LARDELLI, P.; RUIZ-REQUENA, M. E.; ESCOBAR-JIMENEZ, F. Ketoconazole therapy: hormonal and clinical effects in non-tumoral hyperandrogenism. Eur. J. Endocrinol., v. 130, n. 4, p. 333-338, 1994.

VIEIRA, L. Q.; HONDOWICZ, B. D.; AFONSO, L. C.; WYSOCKA, M.; TRINCHIERI, G.; SCOTT, $\mathrm{P}$. Infection with leishmania major induces interleukin-12 production in vivo. Immunol. Lett., v. 40, n. 2, p. 157-161, 1994.

VIGUSHIN, D. M.; POON, G. K.; BODDY, A.; ENGLISH, J.; HALBERT, G. W.; PAGONIS, C.; JARMAN, M.; COOMBES, R. C. Phase $i$ and pharmacokinetic study of d-limonene in patients with advanced cancer. Cancer Chemother. Pharmacol., v. 42, p. 111-117, 1998.

VOET, D.; VOET, J. G. Biochemistry. In: . Toronto: John Wiley e Sons, 1995. cap. Lipid metabolism., p. 662-726.

VOHRINGER, H. F.; ARASTEH, K. Pharmacokinetic optimisation in the treatment of pneumocystis carinii pneumonia. Clin. Pharmacokinet., v. 24, n. 5, p. 388-412, 1993.

VOJTEK, A.; DER, C. Increasing complexity of the ras signaling pathway. J. Biol. Chem., v. 273, n. 32, p. 19925-19928, 1998.

WALTON, B. C. The Leishmaniases in Biology and Medicine. In: . London: Academic Press, 1987. cap. American cutaneous and mucocutaneous leishmaniasis, p. 637664.

WATTENBERG, L. W.; COCCIA, J. B. Inhibition of 4-(methylnitrosamino)-1-(3-pyridyl)-1butanone carcinogenesis in mice by d-limonene and citrus fruit oils. Carcinogenesis., v. 12, n. 1, p. 115-117, 1991.

WILLIAMS, J. E. medical parasitology a practical approach. In: . New York: OxfordUniversity Press, 1995. cap. Leishmania and Trypanosoma, p. 151-176.

YARDLEY, V.; CROFT, S. L.; DONCKER, S. D.; DUJARDIN, J. C.; KOIRALA, S.; RIJAL, S.; MIRANDA, C.; LLANOS-CUENTAS, A.; CHAPPUIS, F. The sensitivity of clinical isolates of leishmania from peru and nepal to miltefosine. Am. J. Trop. Med. Hyg., v. 73, n. 2, p 272-275, 2005.

YOKOYAMA, K.; LIN, Y.; STUART, K. D.; GELB, M. H. Prenylation of proteins in trypanosoma brucei. Mol. Biochem. Parasitol., v. 87, n. 1, p. 61-69, 1997.

YURI, T.; DANBARA, N.; TSUJITA, K. Y.; KIYOZUCA, Y.; SENZAKI, H.; SHIKATA, N.; KANSAKI, H.; TSUBURA, A. Perillyl alcohol inhibits human breast cancer cell growth in vitro and vivo. Breast Cancer Res. Treat., v. 84, n. 3, p. 251-260, 2004.

ZHANG, F. L.; CASEY, P. J. Protein prenylation: molecular mechanisms and functional consequences. Ann. Rev. Biochem., v. 65, p. 241-269, 1996.

ZUNIGA, B.; GUEVARA-FEFER, P.; HERRERA, J.; CONTRERAS, J. L.; VELASCO, L.; PEREZ, F. J.; ESQUIVEL, B. Chemical composition and anti-inflammatory activity of the 
volatile fractions from the bark of eight mexican bursera species. Planta Med., v. 71, n. p. 825-828, 2005. 